\title{
Taken en vaardigheden op het werk
}

Citation for published version (APA):

van den Berg, E., van Eldert, P., Fouarge, D., \& ter Weel, B. (2018). Taken en vaardigheden op het werk: Bevindingen uit de eerste en tweede Nederlandse Skills Survey. ROA. ROA Reports No. 006 https://doi.org/10.26481/umarep.2018006

Document status and date:

Published: 01/01/2018

DOI:

10.26481/umarep.2018006

Document Version:

Publisher's PDF, also known as Version of record

\section{Please check the document version of this publication:}

- A submitted manuscript is the version of the article upon submission and before peer-review. There can be important differences between the submitted version and the official published version of record.

People interested in the research are advised to contact the author for the final version of the publication, or visit the DOI to the publisher's website.

- The final author version and the galley proof are versions of the publication after peer review.

- The final published version features the final layout of the paper including the volume, issue and page numbers.

Link to publication

\footnotetext{
General rights rights.

- You may freely distribute the URL identifying the publication in the public portal. please follow below link for the End User Agreement:

www.umlib.nl/taverne-license

Take down policy

If you believe that this document breaches copyright please contact us at:

repository@maastrichtuniversity.nl

providing details and we will investigate your claim.
}

Copyright and moral rights for the publications made accessible in the public portal are retained by the authors and/or other copyright owners and it is a condition of accessing publications that users recognise and abide by the legal requirements associated with these

- Users may download and print one copy of any publication from the public portal for the purpose of private study or research.

- You may not further distribute the material or use it for any profit-making activity or commercial gain

If the publication is distributed under the terms of Article $25 \mathrm{fa}$ of the Dutch Copyright Act, indicated by the "Taverne" license above, 
Maastricht University

\section{Taken en vaardigheden op het werk Bevindingen uit de eerste en tweede Nederlandse Skills Survey}

\section{ROA Rapport}

ROA-R-2018/6

Researchcentrum voor Onderwijs en Arbeidsmarkt | ROA Research Centre for Education and the Labour Market / ROA 



\section{TAKEN EN VAARDIGHEDEN OP HET}

\section{WERK}

BEVINDINGEN UIT DE EERSTE EN TWEEDE NEDERLANDSE SKILLS SURVEY

ROA-R-2018/6

Emina van den Berg (SEO)

Peter van Eldert (ROA)

Didier Fouarge (ROA)

Bas ter Weel (SEO) 


\section{Colofon}

(C) Researchcentrum voor Onderwijs en Arbeidsmarkt (ROA). Niets uit deze uitgave mag op enige manier worden verveelvoudigd zonder voorafgaande schriftelijke toestemming van de directeur van het ROA.

\section{Researchcentrum voor Onderwijs en Arbeidsmarkt}

Postbus 616

6200 MD Maastricht

$\mathrm{T}+31433883647$

$\mathrm{F}+31433884914$

secretary-roa-sbe@maastrichtuniversity.nl

www.roa.nl

School of Business and Economics

Maastricht University

\section{Vormgeving}

ROA secretariaat, Maastricht

ISBN: 978-90-5321-569-2

september 2018 


\section{INHOUD}

\section{Samenvatting}

1 Inleiding 1

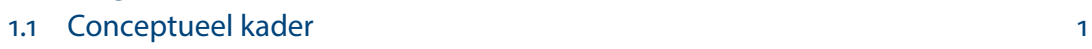

1.2 Taken en vaardigheden tussen en binnen beroepen 2

1.3 Het meten van taken en vaardigheden 3

1.4 Beleidsvragen 3

$\begin{array}{lll}1.5 & \text { Opbouw rapport } & 4\end{array}$

2 Data 5

3 Veranderingen in taken en effectiviteit $\quad 15$

$\begin{array}{ll}\text { 3.1 Belang en effectiviteit van individuele taken } & 15\end{array}$

3.2 Belang en effectiviteit van samenhangende taken 23

$\begin{array}{ll}3.3 & \text { Complexiteit en kunde } \\ \end{array}$

4 Mismatch $\quad 45$

4.1 Skills gap en mismatch 45

4.2 Samenhang tussen persoonskenmerken en mismatch 49

4.3 Relatie mismatch en loon $\quad 55$

4.4 Compenserende mechanismen bij mismatch van taken 58

5 Levenslang leren, loopbaanstappen en taken 65

$\begin{array}{lll}5.1 & \text { Waar leert men vaardigheden } & 65\end{array}$

5.2 Wat is de bijdrage van loopbaanstappen aan de ontwikkeling van
arbeidsvaardigheden?

6 Vraag naar vaardigheden en allocatie van menselijk kapitaal 81

$\begin{array}{ll}\text { 6.1 Vraag naar vaardigheden in beroepen } & 81\end{array}$

6.2 Veranderingen in het werk en taken van werkenden 85 
7 Vergelijking van het belang en de effectiviteit van taken tussen werkenden en niet-werkenden

8 Beleidsconclusie

Literatuur

103

Bijlage A

105 


\section{SAMENVATTING}

Dit onderzoek rapporteert over de eerste en tweede Nederlandse Skills Survey (NSS) die in 2012 en 2017 zijn gehouden. Het doel van de NSS is om tussen en binnen beroepen te kijken naar werktaken en vaardigheden van werkenden in Nederland. In een arbeidsmarkt die verandert kan op deze manier in kaart worden gebracht welke werktaken belangrijker worden en in hoeverre de vaardigheden van werkenden zich in dezelfde richting ontwikkelen, hoe de match tussen vraag en aanbod eruitziet en in hoeverre sprake is van mismatch op de Nederlandse arbeidsmarkt, op welke wijze, wanneer en waar vaardigheden zijn geleerd en in hoeverre sprake is van upgrading in een veranderende arbeidsmarkt, wat de effecten zijn van technologische en organisatorische veranderingen op de vraag naar vaardigheden en in hoeverre dit leidt tot veranderende kansen en uitkomsten voor bepaalde beroepen en groepen op de arbeidsmarkt, en ten slotte wat de vaardigheden zijn van mensen met een afstand tot de arbeidsmarkt en in hoeverre hun vaardigheden passend zijn voor potentiële toekomstige beroepen waarin zij werkzaam zouden willen zijn.

Informatie en kennis over deze ontwikkelingen aan de hand van gedetailleerde informatie over werktaken (vraag) en vaardigheden (aanbod) biedt beleidsmakers handvatten om te beoordelen in hoeverre vraag en aanbod hand-in-hand bewegen, in welke beroepsgroepen mogelijk problemen ontstaan als gevolg van krapte of juist een te ruim aanbod, hoe met technologische verandering wordt omgegaan, welke werknemers het meest investeren in hun duurzame inzetbaarheid en welke groepen een afstand tot de arbeidsmarkt hebben en een inschatting van de omvang daarvan. De survey is nu twee keer gehouden waardoor informatie over een periode van vijf jaar beschikbaar is. Volgende surveys zijn van belang om trends in vraag en aanbod van vaardigheden op structurele wijze te volgen.

De resultaten van dit onderzoek worden hieronder per aandachtsgebied samengevat.

\section{Veranderingen in het belang van werktaken en effectiviteit}

- Omgaan met mensen, samenwerken in een team met anderen en goed luisteren naar collega's zijn en blijven belangrijke taken in de periode 2012-2017. Deze drie 
taken hebben het hoogste belang in de ranglijst van in totaal 33 werktaken die zijn geïnventariseerd in de NSS.

- Tussen 2012 en 2017 zijn verschuivingen te zien in het gemiddelde belang dat door werkenden aan taken wordt gegeven. Het verkopen van een product of dienst, fysieke kracht, uithoudingsvermogen, behendigheid om een taak te verrichten, kennis van het bedienen van apparaten en machines, kennis van specifieke producten en diensten, gespecialiseerde kennis of begrip die niemand anders in de organisatie heeft en het plannen van werkzaamheden van anderen zijn gemiddeld minder belangrijk geworden. De mate waarin verschilt per taak.

- De 33 werktaken kunnen worden geclusterd in acht categorieën. Bij het analyseren van deze categorieën valt op dat weinig taken in belang zijn veranderd tussen 2012 en 2017. Taken waarvan het belang gemiddeld is afgenomen betreffen fysieke behendigheid en kennis van de organisatie.

- De effectiviteit waarmee werktaken worden uitgevoerd is een maat voor vaardigheden - ofwel kwaliteit van het arbeidsaanbod om bepaalde werktaken uit te voeren. Op dit vlak zijn een aantal veranderingen te zien tussen 2012 en 2017. Voorbeelden van taken waarin werkenden gemiddeld effectiever zijn geworden zijn onder andere het houden van presentaties, het maken van berekeningen met decimalen, percentages of fracties en het werken met een computer om producten te ontwerpen, statistische analyses uit te voeren of gecompliceerde berekeningen uit te voeren. Dit past in het beeld dat niet-routinematige en complexere analytische taken belangrijker worden op het werk.

- Ook op effectiviteit is bij vijf van de acht geclusterde categorieën geen verschil waargenomen tussen 2012 en 2017. Bij twee clusters is de effectiviteit over alle beroepen gemiddeld iets gedaald (interpersoonlijke vaardigheden en kennis van de organisatie) en bij een cluster toegenomen (rekenvaardigheden).

- Ongeveer de helft van de werkenden die hebben deelgenomen aan de NSS in zowel 2012 als 2017 is veranderd van beroep. Ook voor deze werkenden geldt dat het belang van taken niet significant is veranderd t.o.v. degenen die nog hetzelfde beroep uitoefenen. Ten aanzien van effectiviteit zijn werkenden met een ander beroep effectiever geworden in rekenvaardigheden dan werkenden in hetzelfde beroep.

- De persoonskenmerken geslacht, leeftijd en opleidingsniveau spelen een belangrijke rol in het verklaren van de effectiviteit van werkenden in het uitvoeren van taken. Vrouwen schatten hun effectiviteit over het algemeen lager in dan mannen. Leeftijd is over het algemeen negatief gecorreleerd met effectiviteit: oudere werkenden schatten hun eigen effectiviteit lager in dan jongeren. Voor opleidingsniveau geldt precies het tegenovergestelde: hoe hoger opgeleid, hoe hoger men de eigen effectiviteit inschat.

- De effectiviteit in het uitvoeren van taken is gerelateerd aan de hoogte van het loon (maar niet noodzakelijk causaal). Werkenden die effectiever zijn in interpersoonlijke vaardigheden, fysieke behendigheid, kennis van de organisatie, plannen en organiseren en computervaardigheden hebben een lager loon. Daarentegen correleert 
een hogere effectiviteit op het terrein van probleemoplossend vermogen, taalvaardigheden en rekenvaardigheden positief met het loon.

- De complexiteit van het werk neemt toe met opleidingsniveau. Dit impliceert dat hoogopgeleiden op hun werk complexere taken uitvoeren dan lager opgeleiden en dat deze taken ook vaker belangrijk zijn. Voor zowel laag- als middelbaar opgeleiden neemt de complexiteit van het werk tot ongeveer 30 jaar gemiddeld toe om vervolgens gestaag af te nemen. Voor hoger opgeleiden neemt de complexiteit van het werk veel langer toe, gemiddeld tot een leeftijd van ongeveer 50 jaar.

\section{De match tussen vraag en aanbod}

- Werkenden zijn volgens eigen zeggen gemiddeld effectiever in het uitvoeren van taken dan het belang dat ze aan diezelfde taken hechten in hun huidige baan. Dit kan een indicatie zijn dat ze meer kunnen dan wat er van hen op het werk gevraagd wordt. Er kan dan sprake zijn van overkwalificatie.

- Bij toepassing van het gemiddelde van de populatie als grenswaarden en indicator van mismatch, blijkt dat er per taak 30 tot 40 procent van de werkenden onder- of overgekwalificeerd is. Onderkwalificatie (gedefinieerd als werktaken met een hoog belang, die worden uitgevoerd met een lage effectiviteit) is relatief het grootst bij kennis van de organisatie. Overkwalificatie (gedefinieerd als werktaken met een laag belang, die worden uitgevoerd met een hoge effectiviteit) is relatief het hoogst bij plannen en organiseren.

- We vinden geen eenduidig verband tussen persoonskenmerken en mismatch. Een hoger opleidingsniveau heeft bijvoorbeeld niet noodzakelijk minder mismatch tot gevolg. Dat geldt ook voor de leeftijd van werkenden en hun geslacht. Mogelijk worden deze uitkomsten verklaard doordat over- en onderkwalificatie tijdelijk van aard zijn en daardoor niet systematisch samenhangen met de onderzochte persoonskenmerken van werkenden.

- Hoe groter het belang van taken is op het werk, hoe hoger de beloning voor werkenden. Fysieke behendigheid is hierbij de enige uitzondering, voor deze taken ligt de beloning juist lager als het belang van dit type werktaken op het werk groter is.

- Voor de meeste taken geldt dat werkenden voor wie het belang van een taak laag is en de effectiviteit in deze taak ook laag is een significant lager uurloon verdienen. Alleen voor fysieke behendigheid geldt, zoals verwacht kan worden, het omgekeerde.

- Een lage effectiviteit in rekenvaardigheden, taalvaardigheden en plannen en organiseren, terwijl het belang in het werk hoog is, gaat gepaard met een statistisch significant lager uurloon ten opzichte van werkenden met een hogere effectiviteit. Een dergelijke mismatch op de andere taken resulteert niet in een significant lager uurloon.

- Een hoge effectiviteit in interpersoonlijke en taalvaardigheden, terwijl het belang laag is, gaat ook gepaard met een significant lager uurloon. Het tegenovergestelde geldt voor fysieke behendigheid. 
- Er zijn twee aanpassingen voor werkenden waarmee het verlies in productiviteit, doordat ze een belangrijke taak niet effectief uit kunnen voeren, voorkomen kan worden: (1) een afname in het belang van de taak of (2) een verbetering van de effectiviteit in het uitvoeren van de taak.

- Werkenden verwachten dat een groot deel van de belangrijke taken die niet effectief worden uitgevoerd over vijf jaar nog steeds belangrijk zullen zijn. Om de effectiviteit in het uitvoeren van de belangrijke taak te verbeteren worden het volgen van een cursus, ervaring opdoen door de taak vaker uit te voeren en samenwerken met een meer ervaren collega het vaakst genoemd.

- Het volgen van een cursus blijkt voornamelijk voor computervaardigheden de beoogde manier te zijn om effectiever te worden in deze taken, al wordt leren door te doen ook vaak voor deze taken genoemd. Voor alle taken geeft meer dan 20 procent van de respondenten aan dat zij de effectiviteit denken te verbeteren door middel van ervaring opdoen en door de taak vaker uit te voeren. Samenwerken met een meer ervaren collega wordt vaak aangegeven als activiteit om de effectiviteit in probleemoplossend vermogen en kennis van de organisatie te verbeteren. Voor plannen en organiseren geeft een groot deel van de respondenten aan dat geen van de activiteiten ertoe zal bijdragen dat de effectiviteit in deze taak wordt verbeterd.

- De manieren waarop men de effectiviteit in het uitvoeren van belangrijke taken denkt te verbeteren verschilt aanmerkelijk naar opleidingsniveau.

\section{Levenslang leren, loopbaanstappen en taken}

- Het merendeel van de vaardigheden wordt voornamelijk op het werk geleerd. Vooral voor probleemoplossend vermogen en plannen en organiseren blijkt dit het geval te zijn. De enige groep vaardigheden die voornamelijk op school geleerd wordt bestaat uit rekenvaardigheden. Fysieke behendigheid wordt voornamelijk op het werk geleerd, hoewel een groot deel van de werkenden deze vaardigheden nooit echt geleerd heeft.

- Middelbaar opgeleiden leren vaardigheden vaker op het werk vergeleken met laagopgeleiden. Tevens leren oudere werkenden een vaardigheid vaker op het werk dan jongere werkenden. Met betrekking tot geslacht komt er geen significant verschil naar voren in de manier waarop men de taken leert. In 2017 werden vaardigheden iets vaker op het werk geleerd vergeleken met 2012.

- Vaardigheden kunnen ook buiten school of het werk geleerd worden. Hierbij is voor de taken interpersoonlijke vaardigheden, fysieke behendigheid, probleemoplossend vermogen en plannen en organiseren de optie van nature aangeboren de meest gekozen optie. Daarnaast wordt voor deze taken ook opvoeding vaak als alternatieve leerwijze genoemd. Voor rekenvaardigheden, taalvaardigheden, kennis van de organisatie en computervaardigheden geeft meer dan 40 procent van de respondenten aan de taak niet op een andere manier te hebben geleerd. Tot slot zijn vrijetijdsactiviteiten voor computervaardigheden een veel voorkomende alternatieve manier van leren. 
- Informeel leren blijkt positief gecorreleerd te zijn met de taakeffectiviteit. Zowel de cursusdeelname als het informeel leren van taken op het werk correleert positief met de effectiviteit van de meeste taken. Daarbij blijkt tevens dat cursusdeelname en informeel leren positief correleren met de algehele taakeffectiviteit, oftewel kunde, en de aansluiting tussen kennis en vaardigheden en het werk.

- De bevindingen omtrent levenslang leren kunnen niet causaal worden geïnterpreteerd. Met name cursusdeelname is niet significant gerelateerd aan kunde. Wel komt naar voren dat werkenden die veel informeel leren hoger scoren op effectiviteit als het gaat om interpersoonlijke vaardigheden, taalvaardigheden en plannen en organiseren.

- Vraag naar vaardigheden en allocatie van menselijk kapitaal

- De werkgelegenheid is in de afgelopen 20 jaar sterker gestegen in beroepen met een hoog niveau van interpersoonlijke vaardigheden, taalvaardigheden, probleemoplossend vermogen, plannen en organiseren en computervaardigheden dan in beroepen met een laag niveau in deze taken. Beroepen die hoog scoren op fysieke behendigheid zijn juist minder snel gegroeid. De werkgelegenheidsontwikkeling in beroepen verschilt nauwelijks van elkaar voor beroepen die hoog of laag scoren op rekenvaardigheden of kennis van de organisatie.

- Vooral beroepen die hoog scoren op taakeffectiviteit in interpersoonlijke vaardigheden, taalvaardigheden, computervaardigheden en in iets mindere mate probleemoplossend vermogen zijn sneller gegroeid dan beroepen die hier laag op scoren.

- De groei van het aantal werkenden is hoger in beroepen met een laag risico op automatisering, terwijl de werkgelegenheid in beroepen met een hoog risico op automatisering nauwelijks is veranderd. Met andere woorden: het werkgelegenheidsaandeel van beroepen met een hoog risico op automatisering is in de afgelopen 20 jaar gedaald.

- Een hoger automatiseringsrisico blijkt gepaard te gaan met een lager uurloon. Dit suggereert dat automatisering niet alleen negatief gecorreleerd is met de werkgelegenheidsontwikkeling in beroepen, maar ook met de beloning/productiviteit in die beroepen. Automatisering is in die beroepen eerder een substituut voor arbeid dan complementair aan arbeid.

- Voor alle taken, behalve fysieke behendigheid, zijn technologische veranderingen positief gecorreleerd met het belang van taken. Deze positieve correlatie is tevens voor organisatorische veranderingen aanwezig, met uitzondering van fysieke behendigheid en rekenvaardigheden.

- De mate van concurrentie op de markt correleert positief met het belang van interpersoonlijke vaardigheden, rekenvaardigheden, computervaardigheden, en in mindere mate met probleemoplossend vermogen. De mate van instabiliteit in de markt correleert echter niet met het belang van taken op het werk en lijkt eerder onzekerheid dan concurrentie te meten.

- Grote technologische ontwikkelingen blijken samen te hangen met een kleinere kans op een tekort aan vaardigheden op het gebied van reken- en computervaardigheden. Ook de kans op een overkwalificatie in probleemoplossend vermogen, 
interpersoonlijke vaardigheden, kennis van de organisatie en computervaardigheden hangt negatief samen met grote technologische veranderingen, al zijn deze verbanden relatief klein.

- Grote organisatorische veranderingen hangen positief samen met de kans op een tekort aan vaardigheden op het terrein van interpersoonlijke vaardigheden en computervaardigheden. Bovendien gaan grote organisatorische veranderingen gepaard met een kleinere kans op een overkwalificatie op het gebied van interpersoonlijke vaardigheden, en een grotere kans daarop in rekenvaardigheden.

- Er bestaat een zwak verband tussen de mate van concurrentie op de markt en de kans op een tekort aan vaardigheden in taalvaardigheden en fysieke behendigheid. Bij een grote mate van concurrentie is tevens sprake van een grotere kans op overkwalificatie in taal- en computervaardigheden. De mate van instabiliteit van de markt correleert niet met deze kansen.

\section{Groepen met een afstand tot de arbeidsmarkt}

- Niet-werkenden nemen ook deel aan de NSS. Binnen deze groep is onderscheid gemaakt tussen personen die op zoek zijn naar werk en personen die dat niet zijn.

- Voor vier van de acht clusters van werktaken (interpersoonlijke vaardigheden, fysieke behendigheid, probleemoplossend vermogen en computervaardigheden) zijn statistisch significante verschillen gevonden tussen werkenden en niet-werkenden. In alle gevallen hechten niet-werkenden gemiddeld een lager belang aan de taken dan werkenden. Bij de overige clusters van werktaken bestaat geen statistisch significant verschil.

- Niet-werkenden zijn gemiddeld minder effectief in het uitvoeren van werktaken dan werkenden. De effectiviteit van niet-werkenden overlapt voor een deel met die van werkenden. De overlap is het grootst bij de groep niet-werkenden die op zoek is naar een baan en waarschijnlijk een kleinere afstand heeft tot de arbeidsmarkt.

- Mismatch wijkt voor niet-werkenden op vijf van de acht clusters van werktaken af van die van werkenden. Niet-werkenden schatten de mate van mismatch veelal lager in dan de werkenden. 


\section{INLEIDING}

\subsection{Conceptueel kader}

In een productieproces leidt het uitvoeren van taken tot output in de vorm van producten of diensten. Sommige taken worden door mensen uitgevoerd, terwijl andere taken door machines uitgevoerd worden. Menstaken, die gebundeld zijn in beroepen, en machinetaken kunnen complementair aan elkaar zijn, maar ook substitueerbaar zijn.' Werkenden kunnen hun kennis en vaardigheden inzetten voor het uitoefenen van taken en verschillen in de mate waarin zij in staat zijn dit effectief en efficiënt uit te voeren. Met andere woorden: vaardigheden zorgen niet direct voor de productie van output, maar alleen als deze vaardigheden gekoppeld zijn aan het effectief en efficiënt uitvoeren van bepaalde taken. In de regel geldt dat de kwaliteit van de vaardigheden hand-in-hand gaat met het belang van de werktaken en dat naarmate de match tussen de effectiviteit waarmee de taak wordt uitgevoerd en het belang van de werktaak groter is, dit leidt tot een hogere productiviteit en beloning.

Deze match tussen vaardigheden en werktaken is niet statisch, maar verandert over de tijd. Autor et al. (2003) en Acemoglu en Autor (2011) wijzen naar technologische ontwikkelingen als verklaring voor de veranderingen in de beroepenstructuur in de Verenigde Staten. Technologische ontwikkelingen leiden tot een toenemende complexiteit van de taken die op het werk door mensen moeten worden uitgevoerd, tot nieuwe taken die werkenden zich eigen moeten maken en tot een grotere inzet van ICT-applicaties. Informatie- en communicatietechnologie (ICT) zorgt echter ook voor een afname in de vraag naar routinematige taken, terwijl niet-routinematige taken die door de mens worden uitgevoerd (nog) niet goed geautomatiseerd kunnen worden. Dit geldt zowel voor handmatige als cognitieve routinetaken die niet eenvoudig in "if-then" principes kunnen worden gevat. Deze ICT-ontwikkelingen gingen in de jaren '70 en '80 gepaard met een verslechtering van de arbeidsmarktpositie van vooral lager opgeleide werkenden, omdat een aantal van hun taken werd geautomatiseerd. Vanaf de jaren '9o ontstaat er polarisering op de arbeidsmarkt, waarbij het middensegment wordt geraakt, omdat dan ook routinematige taken in het middensegment geautomatiseerd worden, het werk zodanig wordt georganiseerd dat veel taken in het middensegment verdwijnen

1 Ter Weel (2018) geeft een overzicht van de verschillende vormen van complementariteit en substitueerbaarheid van taken tussen mens en machine. 
of goedkoper uitgevoerd kunnen worden in het buitenland. ${ }^{2}$ Hoogopgeleiden profiteren daarentegen vanaf de jaren ' 70 van de technologische vernieuwingen, omdat de taken die zij uitvoeren profijt hebben van de ICT waarvan zij gebruik kunnen maken en omdat er nieuwe beroepen zijn ontstaan aan de bovenkant van de arbeidsmarkt. Ook lenen complexe taken zich niet goed voor het verplaatsen daarvan naar landen waar de loonkosten lager zijn, omdat coördinatiekosten dan juist hoger zijn. Deze ontwikkelingen zijn goed gedocumenteerd voor zowel de Verenigde Staten als voor Europese landen, waaronder Nederland. ${ }^{3}$

Omdat de mens een comparatief voordeel heeft ten opzichte van computertechnologie als het gaat om het bedenken van oplossingen voor nieuwe problemen en persoonlijke interacties, groeit het belang van specifieke vaardigheden, zoals probleemoplossend vermogen, communicatieve en sociale vaardigheden in het werk. De werkgelegenheid neemt gemiddeld het sterkst toe in de beroepen met een hoge intensiteit van ICT-gebruik, waarin van werkenden probleemoplossend vermogen wordt gevraagd (Fouarge, 2017a). Dit geldt ook voor beroepen waarvoor een hoge mate van taakautonomie en zelfstandigheid cruciaal is. Een mogelijke verklaring hiervoor is dat de organisatie van werk minder hiërarchisch is geworden en het werken in teamverband in autonoom opererende eenheden steeds vaker gangbaar wordt (Caroli en Van Reenen,2001; Bresnahan et al. 2002; Borghans en Ter Weel 2006; Green et al. 2018).

Daarnaast is er een verschuiving in de vraag richting meer servicegeoriënteerde beroepen die minder onder druk staan van de internationalisering. Deze beroepen vragen om nabijheid en kunnen vanwege de hoge coördinatie- en communicatiekosten veel moeilijker of niet worden uitbesteed. Dit geldt voor de zakelijke dienstverlening en natuurlijk vooral voor schoonmaak-, verzorgings- en horecataken. Dit proces is in de afgelopen decennia versneld, doordat vrouwen meer betaald werk zijn gaan verrichten en taken in het huishouden eenvoudiger zijn geworden als gevolg van nieuwe technologie. Vrouwen hebben een relatief nadeel in fysiek zware taken, maar door de automatisering en de verschuiving naar diensten juist een relatief voordeel in het uitvoeren van meer interpersoonlijke taken (naast het proces van emancipatie; zie Borghans et al. 2014). Door de hogere participatie worden meer taken in het huishouden uitbesteed, wat leidt tot een toenemende behoefte aan huishoudelijke arbeid (zoals schoonmaken en koken) via de markt en tot het afnemen van diensten in de markt die eerder in het huishouden plaatsvonden (bijvoorbeeld kinderopvang, vaker uiteten, meer sporten, vaker uitgaan).

\subsection{Taken en vaardigheden tussen en binnen beroepen}

De taken en vaardigheden die nodig zijn voor het uitoefenen van het werk zijn in zekere mate beroepsspecifiek. Dit geldt zeker voor vakspecifieke taken en vaardigheden die

2 Zie bijvoorbeeld Goos et al. (2014) voor een studie naar polarisatie op de arbeidsmarkt in verschillende OESOlanden en Van den Berge en Ter Weel (2015) voor een studie over de Nederlandse arbeidsmarkt.

3 Zie Los et al. (2015) voor een internationale studie en Akçomak et al. (2011) voor een studie naar Nederland. 
ervoor zorgen dat werkenden niet zomaar van beroep kunnen veranderen. Taken en vaardigheden die een algemener karakter hebben, kunnen echter wel inwisselbaar zijn tussen beroepen en sectoren. Aan de hand van metingen van taken van werkenden in hun beroep kan inzicht worden verschaft in de mate waarin werkenden in het ene beroep (bijvoorbeeld in een relatief ruime markt) inzetbaar zijn in een ander beroep (bijvoorbeeld in een relatief krappe markt).

Maar ook binnen beroepen kunnen grote verschillen in de taken en vaardigheden van de werkenden bestaan. Enerzijds is dit het gevolg van het feit dat beroepen vaak niet specifiek genoeg aangeduid kunnen worden (aggregatieprobleem); anderzijds komt dit doordat werkenden die in de data worden waargenomen in hetzelfde beroep zich specialiseren in verschillende taken of verschillen in hun effectiviteit bij het uitvoeren van taken (heterogeniteit). De oorzaak hiervan kan zowel liggen bij de vraag naar als het aanbod van arbeid.

\subsection{Het meten van taken en vaardigheden}

Het meten van het belang van taken en de kwaliteit van vaardigheden is complex. Er zijn verschillende manieren waarop dit kan worden geoperationaliseerd (zie Ter Weel en Kok, 2013). In het algemeen kan gesteld worden dat het belang van werktaken een indicator is van de arbeidsvraag en dat de effectiviteit waarmee de taken worden uitgevoerd een indicator is van het arbeidsaanbod dat tot stand is gekomen in de markt. Op basis van deze redeneerlijn zijn verschillende studies uitgevoerd die kennis en vaardigheden van werkenden in kaart hebben gebracht om een beeld te geven van de kwaliteit van de beroepsbevolking (bijvoorbeeld de OESO-initiatieven als PIAAC). Ook zijn er verschillende studies uitgevoerd die het belang van werktaken in een beroep in kaart brengen (zoals de handboeken die worden gebruikt voor het in kaart brengen van beroepen in de Verenigde Staten, bijvoorbeeld de Dictionary of Occupational Titles).

Het is de kunst om het belang van werktaken te koppelen aan de vaardigheden van de werkenden en potentieel werkenden. Deze koppeling kan worden gemaakt aan de hand van skills surveys, zoals voor het eerst uitgevoerd in het Verenigd Koninkrijk (British Skills Survey) en nu ook voor de tweede keer in Nederland.

\subsection{Beleidsvragen}

De ministeries van EZK, OCW en SZW hebben ROA en SEO de opdracht gegeven een onderzoek uit te voeren naar de ontwikkeling van vaardigheden in Nederland. Het onderzoek richt zich op vier kennisvragen:

1. Ontwikkelingen vanaf 2012. Welke skills zijn in het werk van belang? Welke ontwikkelingen zijn daarin te zien? Welke wisselwerking is er tussen skills in de zin dat zij elkaar versterken of dat zij voor elkaar compenseren?

2. Match van vaardigheden en taken. Sluiten op individueel niveau de skills van werkenden aan bij de eisen van het werk? Is er een mismatch? Wat heeft een onvol- 
komen aansluiting op de benodigde skills qua niveau (meer of minder dan noodzakelijk) en qua richting voor effect op productiviteit en inkomen?

3. Investeringen in menselijk kapitaal. Op wat voor manieren maken werkenden zich de skills eigen die zij in hun werk nodig hebben? Wat is de bijdrage van leren voor het werk door scholingsactiviteiten en leren van het werk (informeel leren)? Zijn hier compenserende mechanismen waar te nemen? Wat is de bijdrage van loopbaanstappen aan de ontwikkeling van arbeidsvaardigheden?

4. Implicaties. Wat is op meso- en macroniveau de aansluiting van vraag en aanbod van skills? Wat zijn de verliezen als gevolg van een ontoereikende allocatie van menselijk kapitaal?

\subsection{Opbouw rapport}

Deze vragen worden in verschillende hoofdstukken uitgewerkt. De eerste kennisvraag komt met name aan bod in hoofdstuk 3 waarin we veranderingen in taken en effectiviteit tussen 2012 en 2017 schetsen. In hoofdstuk 4 gaan we in op de mismatch tussen het belang van vaardigheden op het werk en de effectiviteit van werkenden in het uitvoeren van hun taken. Dit geeft antwoord op de tweede kennisvraag. De analyses rond de relatie tussen mismatch en loon geven tevens een antwoord op de vierde kennisvraag over mogelijke verliezen aan productiviteit bij een slechte aansluiting tussen gevraagde en aangeboden vaardigheden. In hoofdstuk 5 leggen we een relatie tussen levenslang leren, loopbaanstappen en de taken van werkenden. We geven hiermee invulling aan de derde beleidsvraag. De vierde kennisvraag komt expliciet aan bod in hoofdstuk 6 dat ingaat op de vraag naar vaardigheden en allocatie van menselijk kapitaal. Hoofdstuk 7 gaat in op de perceptie van werklozen van het belang van taken en hun taakeffectiviteit en geeft hiermee een specifiekere invulling aan de tweede kennisvraag. In het afsluitende hoofdstuk, hoofdstuk 8, zetten we de inzichten uit eerdere hoofdstukken op een rij om antwoord te geven op de vraag of er sprake is van een onderinvestering in menselijk kapitaal en of er sprake is van marktfalen.

Om antwoord te geven op deze beleidsvragen wordt gebruik gemaakt van de peilingen 2012 en 2017 van de Nederlandse Skills Survey (zie hoofdstuk 2), het LISS-panel, en de ROA Levenslang Leren Enquête (Fouarge et al., 2018). 


\section{DATA}

\section{Nederlandse Skills Survey}

De voornaamste databron die in dit rapport wordt gebruikt is de Nederlandse Skills Survey (NSS), een enquête gericht op het meten van taken en vaardigheden van werkenden. Deze enquête vormt een onderdeel van het Langlopende Internet Studies voor de Sociale wetenschappen (LISS) van CentERdata (Tilburg University). Het LISSpanel is gebaseerd op een representatieve steekproef van de Nederlandse beroepsbevolking.

Het belangrijkste doel van de NSS is om inzicht te verkrijgen in het belang van verschillende dagelijkse taken op het werk, de mate waarin werkenden deze taken effectief uitvoeren en waar de vaardigheden die deze taken vereisen worden geleerd. In mei 2012 is op verzoek van het CPB en het ROA een eerste meting afgenomen onder de leden van het LISS-panel over het werk en de taken van werkenden (ter Weel en Kok, 2013). Een tweede meting is afgesloten in juli 2017.

De vragen uit de NSS zijn gebaseerd op de British Skills Survey en de kernvragen zijn gelijk gehouden tussen de metingen van 2012 en 2017. Daar waar de NSS 2012 zich uitsluitend richtte op werkenden, is in de meting in 2017 ook aan niet-werkenden gevraagd een inschatting te geven van het belang van de taken in een gewenst beroep en hun effectiviteit in die taken. ${ }^{4}$ Bij de beantwoording van sommige kennisvragen zal specifiek worden ingezoomd op deze groep respondenten.

Voor het beantwoorden van sommige kennisvragen zal tevens op individueel niveau een koppeling worden gelegd tussen de 2017-meting van de NSS en de Levenslang Leren enquête (LLL) die door ROA is uitgevoerd in het kader van het NRO-project 'Levenslang leren en competentieontwikkeling.'5

4 Voor die groep is de formulering van de vragen aangepast. Niet werkenden worden gevraagd wat voor beroep geschikt en haalbaar zou zijn en zij doorlopen de vragenlijst vanuit het perspectief van dat beroep. Niet-werkenden die zich geen geschikt en haalbaar beroep kunnen voorstellen doorlopen de vragenlijst vanuit het perspectief van hun laatste beroep. NRO project 405-16-402. 


\section{Respons en samenstelling}

In dit rapport gaan wij uit van de volgende afbakening van respondenten: werkenden met een baan van 12 uur of meer, die niet ouder zijn dan 66 jaar. Dit is de zogenaamde'oude definitie' van werkenden van CBS. Deze afbakening is noodzakelijk voor vergelijkbaarheid in de tijd omdat dit ook de afbakening is die in 2012 is gehanteerd voor de dataverzameling.

In 2012 zijn 3.883 werkenden benaderd voor de NSS en de respons bedroeg 2.780 (71,6\%). In 2017 zijn 5.106 personen benaderd, zowel werkenden als niet-werkenden. De respons bedroeg 4.220 (82,6\%). 1.126 personen hebben in beide jaren meegedaan, waardoor er een panelanalyse mogelijk is. De samenstelling van de respondenten is in beide jaren vergelijkbaar. Hierbij is onder andere gekeken naar kenmerken als geslacht, positie in het huishouden, burgerlijke staat, woonsituatie, hoogst afgeronde opleiding en salaris. Om deze reden is er geen weging toegepast. In Tabel 2.1 zijn een aantal kenmerken van de werkenden in beide jaren van de NSS weergegeven - de aantallen in 2017 wijken af van de respons vanwege de afbakening in 2012.

TABEL 2.1

Samenstelling van de NSS

\begin{tabular}{|c|c|c|}
\hline & NSS $2012(\mathrm{~N}=2.736)$ & NSS $2017(\mathrm{~N}=1.856)$ \\
\hline \multicolumn{3}{|l|}{ Geslacht } \\
\hline Man & $50,4 \%$ & $52,2 \%$ \\
\hline Vrouw & $49,6 \%$ & $47,9 \%$ \\
\hline \multicolumn{3}{|c|}{ Positie in het huishouden } \\
\hline Huishoudhoofd & $61,6 \%$ & $64,8 \%$ \\
\hline Gehuwde partner & $25,7 \%$ & $22,2 \%$ \\
\hline Ongehuwde partner & $6,9 \%$ & $7,1 \%$ \\
\hline Overig & $5,8 \%$ & $5,9 \%$ \\
\hline \multicolumn{3}{|l|}{ Leeftijd } \\
\hline 18-24 jaar & $3,4 \%$ & $4,1 \%$ \\
\hline 25-34 jaar & $17,4 \%$ & $18,1 \%$ \\
\hline 35-44 jaar & $22,5 \%$ & $25,6 \%$ \\
\hline 45-54 jaar & $29,2 \%$ & $30,5 \%$ \\
\hline 55-64 jaar & $27,5 \%$ & $21,8 \%$ \\
\hline \multicolumn{3}{|c|}{ Hoogste afgeronde opleiding } \\
\hline Basisonderwijs/vmbo & $21,6 \%$ & $16,3 \%$ \\
\hline Mbo/havo/vwo & $37,9 \%$ & $37,5 \%$ \\
\hline Hbo/wo & $40,3 \%$ & $46,2 \%$ \\
\hline Onbekend & $0,3 \%$ & $0,1 \%$ \\
\hline
\end{tabular}




\section{De meting van taken en taakeffectiviteit}

In de NSS worden de taken van werkenden gemeten aan de hand van een lijst van 33 taken. De meting is als volgt ingeleid: "U krijgt nu een aantal vragen voorgelegd over activiteiten die onderdeel zouden kunnen zijn van uw huidige werk. We proberen hiermee het type taken dat u uitvoert op uw werk in beeld te brengen, evenals het belang van die taken om uw werk uit te voeren. Geef van iedere taak aan hoe belangrijk deze taak is in uw werk."

Respondenten kunnen hun antwoord geven op de volgende schaal:

1. 'helemaal niet belangrijk / niet van toepassing',

2.'niet erg belangrijk',

3. 'redelijk belangrijk',

4. 'erg belangrijk' of

5. 'cruciaal'.

De vraag wordt gesteld voor de volgende lijst van taken, waarbij de volgorde tussen respondenten is gerandomiseerd om bias in antwoorden te voorkomen en taken 34 en 35 enkel in 2017 zijn opgenomen: ${ }^{6}$

1. Omgaan met mensen

2. Samenwerken in een team met anderen

3. Goed luisteren naar collega's

4. Instrueren, trainen of iets leren aan anderen

5. Houden van presentaties

6. Verkopen van een product of een dienst

7. Overtuigen en beïnvloeden van anderen

8. Adviseren en begeleiden van klanten of cliënten

9. Fysieke kracht

10. Uithoudingsvermogen

11. Behendigheid om een taak te verrichten

12. Kennis van het bedienen van apparaten en machines

13. Kennis van specifieke producten of diensten

14. Gespecialiseerde kennis of begrip die niemand anders in de organisatie heeft

15. Kennis van hoe de organisatie van het bedrijf in elkaar zit en werkt

16. Opmerken van fouten of problemen

17. Oplossen van problemen

18. Analyseren van problemen

19. Controleren om te voorkomen dat er fouten worden gemaakt of problemen ontstaan

6 Taak 34 is toegevoegd om meer zicht te krijgen op de interacties op het werk. Taak 35 is toegevoegd als meting van hoogwaardige ICT-taken. Afgezien van hoofdstuk 3 worden deze nieuwe taken van 2017 buiten beschouwing gelaten. 
20. Plannen van uw eigen werkzaamheden

21. Plannen van de werkzaamheden van anderen

22. Lezen en beoordelen van formulieren

23. Lezen en beoordelen van korte rapporten, brieven of memo's

24. Lezen en beoordelen van lange rapporten, brieven of memo's

25. Invullen van formulieren

26. Schrijven van korte rapporten, brieven of memo's

27. Schrijven van lange rapporten, brieven of memo's

28. Optellen, aftrekken, vermenigvuldigen en delen van getallen

29. Maken van berekeningen met decimalen, percentages of fracties

30. Gebruik van wiskunde of statistiek om berekeningen te maken

31. Werken met een computer om bijvoorbeeld klantgegevens in te voeren en rekeningen te printen

32. Werken met een computer om documenten op te stellen, met spreadsheets te werken, informatie op het internet te zoeken of e-mails te versturen

33. Werken met een computer om producten te ontwerpen, statistische analyses uit te voeren of gecompliceerde berekeningen uit te voeren

34. Geven van feedback aan collega's

35. Kennis van specifieke software of programmeertalen

$\mathrm{Na}$ het belang van taken te hebben vastgesteld is aan respondenten gevraagd hoe effectief zij zijn in het uitvoeren van elk van die taken en waar zij dit hebben geleerd. De taakeffectiviteit wordt gemeten op een schaal van 1 tot 5 :
1. 'bijna nooit',
2. 'soms',
3. 'vaak',
4. 'bijna altijd', of
5. 'altijd'.

Waar men de vaardigheid heeft geleerd wordt ook op een 5-puntsschaal gemeten:
1. 'op school',
2. 'meer op school dan op het werk',
3. 'evenveel op school als op het werk',
4. 'meer op het werk dan op school', of
5. 'op het werk'.

Voor de analyses worden de vaardigheden geclusterd volgens de door Borghans et al. (2008) voorgestelde indeling op basis van analyses voor Duitsland, het Verenigd Koninkrijk en de Verenigde Staten. Tabel 2.2 geeft de indeling van vaardigheden in clusters - dit wordt verder toegelicht in paragraaf 3.2. 
TABEL 2.2

Clustering van taken

\begin{tabular}{|l|l|}
\hline Groep & Taken \\
\hline Interpersoonlijke vaardigheden & $1-8$ \\
\hline Fysieke behendigheid & $9-11$ \\
\hline Kennis van de organisatie & $12-15$ \\
\hline Probleemoplossend vermogen & $16-19$ \\
\hline Plannen en organiseren & $20-21$ \\
\hline Taalvaardigheden & $22-27$ \\
\hline Rekenvaardigheden & $28-30$ \\
\hline Computervaardigheden & $31-33$ \\
\hline
\end{tabular}

\section{Waar leert men nog meer?}

Voor drie taken worden de respondenten gevraagd aan te geven hoe zij denken de effectiviteit van de vaardigheden te kunnen vergoten. Verder wordt ook gevraagd waar men de vaardigheden nog meer heeft geleerd, oftewel buiten school of werk. De drie taken verschillen tussen respondenten. Tabel 2.3 geeft de vragen weer.

TABEL 2.3

Afleiding van drie specifieke taken?

\begin{tabular}{|l|l|}
\hline Taak: & Beschrijving: \\
\hline Taak die belangrijker gaat worden (Taak A) & $\begin{array}{l}\text { In de vragenlijst wordt aan werkenden gevraagd } 4 \text { taken aan } \\
\text { te geven die in belang zullen toenemen als men van baan zou } \\
\text { veranderen. Een van deze taken wordt random geselecteerd. }\end{array}$ \\
\hline Een belangrijke taak (Taak B) & \begin{tabular}{l} 
Een belangrijke taak uit de lijst van 35, zijnde niet Taak A \\
\hline Taak waar men niet effectief in is (Taak C)
\end{tabular} \\
$\begin{array}{l}\text { Een belangrijke taak uit de lijst van } 35 \text { die niet effectief wordt } \\
\text { uitgevoerd, zijnde niet Taak A of B. }\end{array}$ \\
\hline
\end{tabular}

Voor alle drie de taken wordt aan respondenten gevraagd 'Hoeveel procent van het loon zijn ze bereid in te leveren of zouden ze meer willen hebben om een taak niet meer uit te voeren'.

Voor Taak B wordt gevraagd waar men dit buiten school of werk nog meer geleerd heeft:
a) Vrijwilligerswerk/mantelzorg;
b) Activiteiten met kinderen;
c) Vrijetijdsactiviteiten;
d) Opvoeding;
e) Van nature aangeboren;

7 In Bijlage A wordt er in een tabel weergegeven welke taken als Taak A t/m C zijn weergegeven aan de respondenten voor de vervolgvragen, geclusterd naar groep. 
f) Anders; of

g) Geen van deze activiteiten.

Voor Taak $\mathrm{C}$ wordt gevraagd of men denkt dat de taak meer of minder belangrijk gaat worden in het werk tussen nu en 2022 en hoe men denkt de effectiviteit te kunnen vergroten via:

a) Cursus;

b) Geaccrediteerde opleiding;

c) Ervaring opdoen door taak vaker uit te voeren;

d) Samenwerken met een meer ervaren collega;

e) Aanpassingen aan werkomgeving/-tempo;

f) Behandeling fysieke klachten (alleen een optie als het ging om een taak binnen de groep 'Fysieke behendigheid);

g) Anders; of

h) Geen van deze activiteiten.

Over Taak C rapporteren we in hoofdstuk 4 in het kader van de mismatch. Taak B komt in hoofdstuk 5 aan bod.

\section{Niet-werkenden}

In 2017 zijn de vragen over taken en taakeffectiviteit ook gesteld aan mensen die geen werk hebben. Hierbij is aan de respondenten zonder baan eerst gevraagd zich voor te stellen dat zij werk zouden hebben, en vervolgens welke soort beroep geschikt en haalbaar zou zijn. Daarna is gevraagd naar het belang van taken in die geschikte en haalbare baan en naar hun huidige effectiviteit in het uitvoeren van die taken. De resultaten van dit deel van de enquête komen aan bod in hoofdstuk 7.

\section{Voor- en nadelen van de NSS}

De groeiende interesse in het meten van werktaken binnen beroepen heeft geleid tot het verzamelen en analyseren van twee type datasets met expliciete informatie over werktaken van werkenden: 1) databases op basis van expertmetingen over de werktaken in een beroep en 2) metingen door middel van enquêtes waarin werkenden wordt gevraagd naar hun taken.

De veel gebruikte dataset Dictionary of Occupational Titles (DOT) en diens opvolger de Occupational Information Network ( $0^{*} \mathrm{NET}$ ) schetsen het belang van taken per beroep. Experts kennen een belang van taken aan beroepen toe. Deze toekenning gebeurt systematisch, nauwkeurig en onafhankelijk en is daardoor relatief betrouwbaar. In aanvulling op de beroepsstatistieken - die slechts de werkgelegenheid per beroep weergeven - verschaffen DOT en O*NET informatie over de overeenkomsten tussen beroepen wat betreft het takenpakket. Zo wordt het belang van fysieke behendigheid 
voor elk beroep weergegeven. Nadeel van deze datasets is dat de heterogeniteit van het belang van taken binnen beroepen buiten beschouwing blijft. Bovendien lijken de periodieke verschuivingen die worden waargenomen bij een nieuwe editie hoofdzakelijk gebaseerd op werkgelegenheidsverschuivingen tussen beroepen (zoals in Autor et al., 2003). Updates van deze datasets vinden daarnaast niet vaak plaats en weerspiegelen veelal een verbetering van eerdere beschrijvingen in plaats van een verschuiving over de tijd (Miller et al., 1980).

Enquêtes onder werkenden vormen een tweede informatiebron voor takenpakketten van beroepen. Naast standaardvragen over beroep, opleiding, leeftijd en dergelijke, worden vragen over het takenpakket van de baan gesteld in (onder andere) de IAB/ BIBB-survey in Duitsland en de verschillende skills surveys die in het Verenigd Koninkrijk zijn gehouden en in andere landen, zoals Italië, Nieuw Zeeland, Singapore en Spanje. Deze enquêtes belichten de heterogeniteit van taken tussen werkenden met eenzelfde beroep door het belang van taken en de effectiviteit waarmee werkenden ze uitvoeren, in kaart te brengen. Bovendien vinden er van diverse surveys frequente updates plaats die gedegen analyses van de inhoud van banen over de tijd mogelijk maken. De IAB/ BIBB is bijvoorbeeld in 1979, 1986, 1992, 1999, 2006 en 2012 gehouden en de skills surveys in het Verenigd Koninkrijk in 1997, 2001, 2006 en 2012. In Duitsland worden de taken van werkenden tevens gemonitord als onderdeel van een panel studie met herhaalde metingen onder dezelfde respondenten (evenals NSS): Panel "WeLL" 2009, 2010, 2011 en 2012. Er kleven echter ook enkele nadelen aan deze enquêtes. Zo kunnen de vragen over taken abstract en moeilijk te beantwoorden zijn voor respondenten. Omdat de set van werktaken in alle beroepen moeten kunnen voorkomen en het aantal mogelijke vragen beperkt is, zijn de beschrijvingen van taken algemeen en minder gedetailleerd dan in bijvoorbeeld de DOT en O*NET. Een tweede nadeel is dat de enquêtes over de tijd soms niet dezelfde zijn. Dit bemoeilijkt het monitoren van veranderingen over de tijd. Bovendien kan de subjectiviteit van werkenden over hun eigen taken en effectiviteit leiden tot een bias. Spenner (1990) laat echter zien dat dit over het algemeen meevalt.

Tot slot kampen beide manieren van analyseren met een aantal praktische problemen. Ten eerste zijn de beschrijvingen van taken of algemeen, wat heterogeniteit onderbelicht, of specifiek, wat vergelijkingen en aggregatie bemoeilijkt. Ten tweede vergroot het abstracte en relatief onbekende karakter van taken de kans op meetfouten. De codering en inschatting van het belang of niveau van taken vormt een derde praktisch probleem. Wordt het belang van taken uitgedrukt in de hoeveelheid tijd die hieraan wordt besteed, of bijvoorbeeld aan de gevolgen als deze taken niet juist worden uitgevoerd? Tot slot zijn deze datasets duur om te verzamelen waardoor slechts voor enkele landen informatie beschikbaar is en zijn internationale taakstromen en handel in taken grotendeels onbekenden in de statistieken. Dit maakt systematische analyses op macro-economisch niveau onmogelijk. 
In landen van de Organisatie voor Economische Samenwerking en Ontwikkeling (OESO) is in 2012 een begin gemaakt met het periodiek meten van het niveau van vaardigheden in de populatie. Het instrument hiervoor is PIAAC (Programme for the International Assessment of Adult Competencies). De vaardigheden zijn gemeten door middel van uitvoerige, objectieve testen (OECD, 2013). Het betreft functionele vaardigheden die nodig zijn om informatie uit het dagelijks leven te begrijpen en te gebruiken. PIAAC meet een drietal vaardigheden:

- "Taalvaardigheden: Het vermogen om gebruik te maken van geschreven informatie om te functioneren in de maatschappij, de eigen doelen te verwezenlijken en de eigen kennis en mogelijkheden te ontwikkelen.

- Rekenvaardigheden: Het vermogen om mathematische informatie en ideeën te gebruiken, te interpreteren en te delen om zo om te gaan met wiskundige eisen in uiteenlopende situaties.

- Probleemoplossend vermogen in digitale omgevingen: Het vermogen om digitale technologie en communicatiemiddelen te gebruiken om informatie te verkrijgen en te evalueren, met anderen te communiceren en praktische taken te verrichten." (Buisman et al., 2013, p. 18).

Drie nadelen kleven aan PIAAC. Ten eerste, de gemeten vaardigheden zijn indicatief voor de effectiviteit, maar zeggen niets over de vraag naar vaardigheden. Ten tweede, de dataverzameling is duur. Ten derde, mede door de hoge kosten, kunnen niet alle vaardigheden gemeten worden.

Ondanks de verschillen in meting tussen NSS en PIAAC laat Figuur 2.1 voor 2012 zien dat de inschatting van werkenden in beroepen over hun effectiviteit op het terrein van taal, rekenen en probleemoplossend vermogen sterk en significant correleert met de objectieve meting van vaardigheden van werkenden in diezelfde beroepen. 
FIGUUR 2.1

Relatie tussen in NSS en PIAAC gemeten vaardigheden
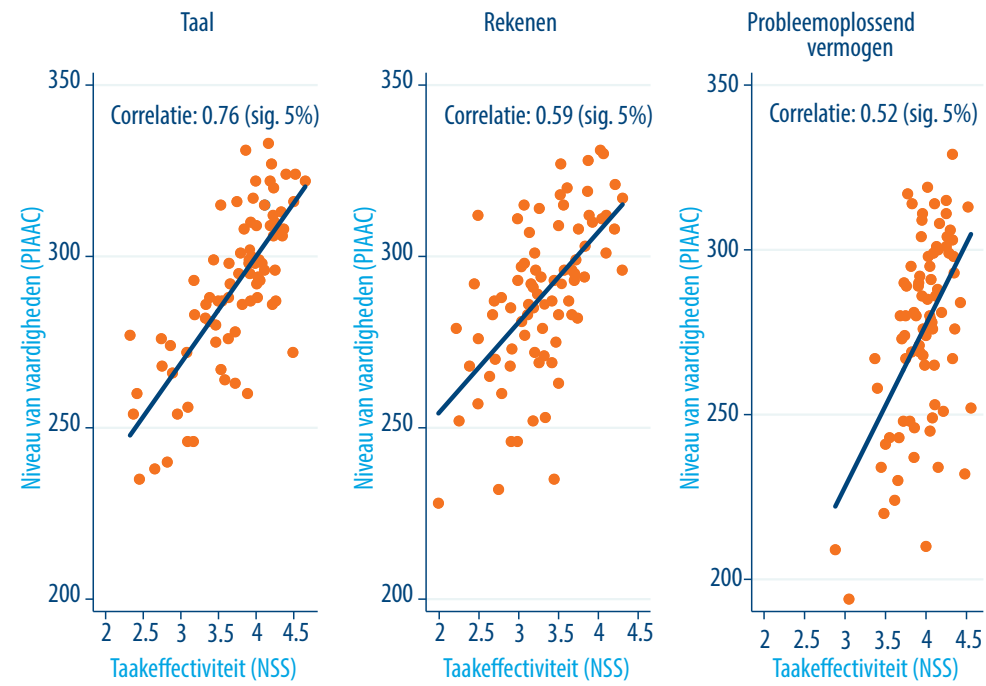



\section{VERANDERINGEN IN TAKEN EN EFFECTIVITEIT}

\subsection{Belang en effectiviteit van individuele taken}

Het omgaan met mensen (taak 1), samenwerken in een team met anderen (taak 2) en goed luisteren naar collega's (taak 3 ) zijn en blijven belangrijke taken volgens werkenden, zie Tabel 3.1. Deze drie taken staan bovenaan de ranglijst van in totaal 33 werktaken die zijn geïnventariseerd in de NSS. Tussen 2012 en 2017 zijn een aantal ontwikkelingen te zien in het gemiddelde belang dat door werkenden aan taken wordt gegeven. Over het algemeen valt op dat de scores in 2017 gemiddeld lager liggen dan in 2012. Het verkopen van een product of dienst (taak 6), fysieke kracht (taak 9), uithoudingsvermogen (taak 10), behendigheid om een taak te verrichten (taak 11), kennis van het bedienen van apparaten en machines (taak 12), kennis van specifieke producten en diensten (taak 13), gespecialiseerde kennis of begrip die niemand anders in de organisatie heeft (taak 14) en het plannen van werkzaamheden van anderen (taak 21) zijn gemiddeld genomen minder belangrijk geworden onder werkenden in Nederland. De mate waarin verschilt per taak. Er zijn in de periode 2012-2017 geen taken die in absolute zin gemiddeld (statistisch significant) belangrijker zijn geworden. Dit is mogelijk het gevolg van de schaal waarop het belang wordt gemeten en het hoge belang dat er gemiddeld gezien al was in 2012.

De top drie in de ranglijst van het belang van taken sluit één-op-één aan bij de top drie in de ranglijst van de effectiviteit van taken (de mate waarin een werkende in staat is op een effectieve wijze invulling te geven aan een taak). Daarentegen zijn er op taakeffectiviteit meer (statistisch significante) absolute veranderingen te zien tussen 2012 en 2017 dan bij het belang van taken. Voor acht taken is de effectiviteit omhooggegaan. Dit betreft onder andere het houden van presentaties (taak 5 ), het maken van berekeningen met decimalen, percentages of fracties (taak 29) en het werken met een computer om producten te ontwerpen, statistische analyses uit te voeren of gecompliceerde berekeningen uit te voeren (taak 33).

Voor het geven van feedback aan collega's en de kennis van specifieke software of programmeertalen (taken 34 en 35 ) is het niet mogelijk om de ontwikkeling vast te stellen, omdat deze beide taken alleen in 2017 zijn voorgelegd aan werkenden. 
TABEL 3.1

Absolute verandering in belang en effectiviteit

\begin{tabular}{|c|c|c|c|c|c|c|}
\hline \multirow[t]{2}{*}{ Individuele taken } & \multicolumn{3}{|c|}{ Absoluut belang ${ }^{1)}$} & \multicolumn{3}{|c|}{$\begin{array}{l}\text { Absolute } \\
\text { effectiviteit }{ }^{2)}\end{array}$} \\
\hline & 2012 & 2017 & $\Delta^{3)}$ & 2012 & 2017 & $\Delta^{3)}$ \\
\hline 1. Omgaan met mensen & 4,04 & 4,06 & n.s. & 4,31 & 4,05 & $* *$ \\
\hline 2. Samenwerken in een team met anderen & 3,77 & 3,77 & n.s. & 4,25 & 4,06 & $* *$ \\
\hline 3. Goed luisteren naar collega's & 3,72 & 3,69 & n.s. & 4,20 & 4,07 & $* *$ \\
\hline 4. Instrueren, trainen of iets leren aan anderen & 2,93 & 2,94 & n.s. & 3,75 & 3,45 & ** \\
\hline 5. Houden van presentaties & 2,34 & 2,34 & n.s. & 3,27 & 3,43 & ** \\
\hline 6. Verkopen van een product of een dienst & 2,26 & 2,15 & ** & 3,01 & 3,44 & ** \\
\hline 7. Overtuigen en beïnvloeden van anderen & 3,04 & 3,04 & n.s. & 3,42 & 3,41 & n.s. \\
\hline 8. Adviseren en begeleiden van klanten of clienten & 3,17 & 3,15 & n.s. & 3,56 & 3,42 & ** \\
\hline 9. Fysieke kracht & 2,25 & 2,17 & * & 3,23 & 3,50 & ** \\
\hline 10. Uithoudingsvermogen & 2,65 & 2,56 & ** & 3,54 & 3,49 & n.s. \\
\hline 11. Behendigheid om een taak te verrichten & 3,24 & 3,17 & * & 3,81 & 3,49 & ** \\
\hline 12. Kennis van het bedienen van apparaten en machines & 2,62 & 2,44 & ** & 3,42 & 3,42 & n.s. \\
\hline 13. Kennis van specifieke producten of diensten & 3,37 & 3,26 & $* *$ & 3,71 & 3,34 & ** \\
\hline $\begin{array}{l}\text { 14. Gespecialiseerde kennis of begrip die niemand anders in de organisatie } \\
\text { heeft }\end{array}$ & 2,82 & 2,71 & ** & 3,54 & 3,33 & ** \\
\hline 15. Kennis van hoe de organisatie van het bedrijf in elkaar zit en werkt & 3,13 & 3,09 & n.s. & 3,57 & 3,36 & ** \\
\hline 16. Opmerken van fouten of problemen & 3,57 & 3,52 & n.s. & 4,01 & 3,91 & ** \\
\hline 17. Oplossen van problemen & 3,67 & 3,64 & n.s. & 4,01 & 3,94 & * \\
\hline 18. Analyseren van problemen & 3,44 & 3,39 & n.s. & 3,84 & 3,89 & n.s. \\
\hline $\begin{array}{l}\text { 19. Controleren om te voorkomen dat er fouten worden gemaakt of } \\
\text { problemen ontstaan }\end{array}$ & 3,40 & 3,36 & n.s. & 3,89 & 3,93 & n.s. \\
\hline 20. Plannen van uw eigen werkzaamheden & 3,63 & 3,65 & n.s. & 4,20 & 3,84 & ** \\
\hline 21. Plannen van de werkzaamheden van anderen & 2,55 & 2,46 & * & 3,54 & 3,79 & ** \\
\hline 22. Lezen en beoordelen van formulieren & 2,70 & 2,77 & n.s. & 3,82 & 3,70 & ** \\
\hline 23. Lezen en beoordelen van korte rapporten, brieven of memo's & 2,89 & 2,92 & n.s. & 3,85 & 3,70 & $* *$ \\
\hline 24. Lezen en beoordelen van lange rapporten, brieven of memo's & 2,59 & 2,66 & n.s. & 3,53 & 3,71 & $* *$ \\
\hline 25. Invullen van formulieren & 2,88 & 2,89 & n.s. & 4,06 & 3,69 & ** \\
\hline 26. Schrijven van korte rapporten, brieven of memo's & 2,95 & 2,94 & n.s. & 3,83 & 3,73 & ** \\
\hline 27. Schrijven van lange rapporten, brieven of memo's & 2,49 & 2,49 & n.s. & 3,38 & 3,72 & ** \\
\hline 28. Optellen, aftrekken, vermenigvuldigen en delen van getallen & 2,51 & 2,54 & n.s. & 3,97 & 3,35 & ** \\
\hline 29. Maken van berekeningen met decimalen, percentages of fracties & 2,15 & 2,18 & n.s. & 3,20 & 3,34 & ** \\
\hline 30. Gebruik van wiskunde of statistiek om berekeningen te maken & 1,88 & 1,91 & n.s. & 2,63 & 3,35 & $* *$ \\
\hline $\begin{array}{l}\text { 31. Werken met een computer om bijvoorbeeld klantgegevens in te voeren en } \\
\text { rekeningen te printen }\end{array}$ & 2,65 & 2,63 & n.s. & 3,66 & 3,39 & $* *$ \\
\hline
\end{tabular}


32. Werken met een computer om documenten op te stellen, met spreadsheets te werken, informatie op het internet te zoeken of e-mails te versturen

33. Werken met een computer om producten te ontwerpen, statistische analyses uit te voeren of gecompliceerde berekeningen uit te voeren

34. Geven van feedback aan collega's

35. Kennis van specifieke software of programmeertalen Gemiddelde van taak 1-33

\begin{tabular}{|l|l|l|l|l|l|}
\hline 3,35 & 3,36 & n.s. & 3,75 & 3,37 & $* *$ \\
\hline 2,10 & 2,06 & n.s. & 2,56 & 3,34 & $* *$ \\
\hline & 3,36 & - & & 4,05 & - \\
\hline- & 2,44 & - & & 3,33 & - \\
\hline 2,93 & 2,91 & n.s. & 3,65 & 3,60 & $*$ \\
\hline
\end{tabular}

1) betreft het gemiddelde van een vijfpunt-Likertschaal, waarbij $1=$ helemaal niet belangrijk/niet van toepassing; $2=$ niet erg belangrijk; $3=$ =redelijk belangrijk; $4=$ =rg belangrijk; $5=$ cruciaal

2) betreft het gemiddelde van een vijfpunt-Likertschaal, waarbij 1=bijna nooit;5=altijd

3) betreft het significantieniveau van het verschil tussen 2017 en 2012, waarbij n.s.= niet significant verschillend van nul; * $=5 \%$-significant; ${ }^{* *}=1 \%$-significant

Bron: NSS 2012 en 2017

Naast het vaststellen van absolute veranderingen tussen 2012 en 2017 op het gebied het belang en de effectiviteit van taken, is het ook mogelijk om naar relatieve veranderingen te kijken, ten opzichte van het gemiddelde van alle taken (Tabel 3.2). Door de absolute afname van het belang van bepaalde taken, zijn een aantal taken die in absolute zin niet zijn toegenomen in belang relatief gezien wel belangrijker geworden. Dit betreft het omgaan met mensen (taak 1), het lezen en beoordelen van formulieren (taak 22) en het lezen en beoordelen van lange rapporten, brieven of memo's (taak 24). Vijf van de acht taken die in absolute zin minder belangrijk zijn geworden, zijn ook relatief in belang gedaald. Dit betreft het verkopen van een product of dienst (taak 6), uithoudingsvermogen (taak 10), kennis van het bedienen van machines en apparaten (taak 12), kennis van specifieke producten of diensten (taak 13) en gespecialiseerde kennis of begrip die niemand anders in de organisatie heeft (taak 14).

De relatieve veranderingen in effectiviteit geven hetzelfde beeld als de absolute veranderingen. Taken die in absolute zin zijn gedaald in effectiviteit, zijn ook in relatieve zin gedaald en vice versa. 
TABEL 3.2

Relatieve verandering in belang en effectiviteit

\begin{tabular}{|c|c|c|c|c|c|c|}
\hline \multirow[t]{2}{*}{$\begin{array}{l}\text { Individuele taken uitgedrukt in een ratio van het gemiddelde van alle } 33 \\
\text { taken }\end{array}$} & \multicolumn{3}{|c|}{ Relatief belang ${ }^{1)}$} & \multicolumn{3}{|c|}{$\begin{array}{l}\text { Relatieve } \\
\text { effectiviteit }^{2)}\end{array}$} \\
\hline & 2012 & 2017 & $\Delta^{3)}$ & 2012 & 2017 & $\left.\Delta^{3}\right)$ \\
\hline 1. Omgaan met mensen & 1,38 & 1,40 & * & 1,18 & 1,13 & *** \\
\hline 2. Samenwerken in een team met anderen & 1,29 & 1,30 & n.s. & 1,17 & 1,13 & ** \\
\hline 3. Goed luisteren naar collega's & 1,27 & 1,27 & n.s. & 1,15 & 1,13 & * \\
\hline 4. Instrueren, trainen of iets leren aan anderen & 1,00 & 1,01 & n.s. & 1,03 & 0,96 & $* *$ \\
\hline 5. Houden van presentaties & 0,80 & 0,81 & n.s. & 0,90 & 0,95 & $* *$ \\
\hline 6. Verkopen van een product of een dienst & 0,77 & 0,74 & * & 0,82 & 0,96 & $* *$ \\
\hline 7. Overtuigen en beïnvloeden van anderen & 1,04 & 1,05 & n.s. & 0,94 & 0,95 & n.s. \\
\hline 8. Adviseren en begeleiden van klanten of clienten & 1,08 & 1,08 & n.s. & 0,98 & 0,95 & * \\
\hline 9. Fysieke kracht & 0,77 & 0,75 & n.s. & 0,88 & 0,97 & $* *$ \\
\hline 10. Uithoudingsvermogen & 0,90 & 0,88 & * & 0,97 & 0,97 & n.s. \\
\hline 11. Behendigheid om een taak te verrichten & 1,11 & 1,09 & n.s. & 1,04 & 0,97 & ** \\
\hline 12. Kennis van het bedienen van apparaten en machines & 0,89 & 0,84 & $* *$ & 0,94 & 0,95 & n.s. \\
\hline 13. Kennis van specifieke producten of diensten & 1,15 & 1,12 & * & 1,02 & 0,93 & $* *$ \\
\hline $\begin{array}{l}\text { 14. Gespecialiseerde kennis of begrip die niemand anders in de organisatie } \\
\text { heeft }\end{array}$ & 0,96 & 0,93 & * & 0,97 & 0,92 & $* *$ \\
\hline 15. Kennis van hoe de organisatie van het bedrijf in elkaar zit en werkt & 1,07 & 1,06 & n.s. & 0,98 & 0,93 & ** \\
\hline 16. Opmerken van fouten of problemen & 1,22 & 1,21 & n.s. & 1,10 & 1,09 & n.s. \\
\hline 17. Oplossen van problemen & 1,25 & 1,25 & n.s. & 1,10 & 1,09 & n.s. \\
\hline 18. Analyseren van problemen & 1,17 & 1,17 & n.s. & 1,05 & 1,08 & ** \\
\hline $\begin{array}{l}\text { 19. Controleren om te voorkomen dat er fouten worden gemaakt of } \\
\text { problemen ontstaan }\end{array}$ & 1,16 & 1,16 & n.s. & 1,07 & 1,09 & ** \\
\hline 20. Plannen van uw eigen werkzaamheden & 1,24 & 1,25 & n.s. & 1,15 & 1,07 & $* *$ \\
\hline 21. Plannen van de werkzaamheden van anderen & 0,87 & 0,85 & n.s. & 0,97 & 1,05 & ** \\
\hline 22. Lezen en beoordelen van formulieren & 0,92 & 0,95 & * & 1,05 & 1,03 & * \\
\hline 23. Lezen en beoordelen van korte rapporten, brieven of memo's & 0,98 & 1,01 & n.s. & 1,06 & 1,03 & $* *$ \\
\hline 24. Lezen en beoordelen van lange rapporten, brieven of memo's & 0,88 & 0,91 & * & 0,97 & 1,03 & $* *$ \\
\hline 25. Invullen van formulieren & 0,98 & 0,99 & n.s. & 1,11 & 1,03 & ** \\
\hline 26. Schrijven van korte rapporten, brieven of memo's & 1,01 & 1,01 & n.s. & 1,05 & 1,04 & n.s. \\
\hline 27. Schrijven van lange rapporten, brieven of memo's & 0,85 & 0,86 & n.s. & 0,93 & 1,03 & ** \\
\hline 28. Optellen, aftrekken, vermenigvuldigen en delen van getallen & 0,86 & 0,87 & n.s. & 1,09 & 0,93 & ** \\
\hline 29. Maken van berekeningen met decimalen, percentages of fracties & 0,73 & 0,75 & n.s. & 0,88 & 0,93 & ** \\
\hline 30. Gebruik van wiskunde of statistiek om berekeningen te maken & 0,64 & 0,66 & n.s. & 0,72 & 0,93 & $* *$ \\
\hline $\begin{array}{l}\text { 31. Werken met een computer om bijvoorbeeld klantgegevens in te voeren en } \\
\text { rekeningen te printen }\end{array}$ & 0,90 & 0,90 & n.s. & 1,01 & 0,94 & $* *$ \\
\hline
\end{tabular}


32. Werken met een computer om documenten op te stellen, met spreadsheets te werken, informatie op het internet te zoeken of e-mails te versturen

33. Werken met een computer om producten te ontwerpen, statistische analyses uit te voeren of gecompliceerde berekeningen uit te voeren

Gemiddelde van taak 1-33 \begin{tabular}{l|l|l|l|l}
1,14 & 1,15 & n.s. & 1,03 & 0,94
\end{tabular}$* *$

\begin{tabular}{lll|l|l|l}
0,72 & 0,71 & n.s. & 0,70 & 0,93 & $* *$
\end{tabular}

$2,93 \quad 2,91 \quad$ n.s. $\quad 3,65 \quad 3,60 \quad$ *

1) betreft het gemiddelde van een vijfpunt-Likertschaal, waarbij $1=$ helemaal niet belangrijk/niet van toepassing; $2=$ niet erg belangrijk; $3=$ =redelijk belangrijk; $4=$ =erg belangrijk; $5=$ cruciaal

2) betreft het gemiddelde van een vijfpunt-Likertschaal, waarbij $1=$ bijna nooit; $5=$ altijd

3) betreft het significantieniveau van het verschil tussen 2017 en 2012, waarbij n.s. = niet significant verschillend van nul; ${ }^{*}=5 \%$-significant; ${ }^{* *}=1 \%$-significant

Bron: NSS 2012 en 2017

Er bestaat een sterk positief verband tussen het gemiddelde belang van taken en de gemiddelde effectiviteit waarmee ze worden uitgevoerd. Dat geldt zowel voor werkenden in 2012 (Figuur 3.1) als voor werkenden in 2017 (Figuur 3.2). De correlatiecoëfficiënt is wel gedaald van o,84 naar 0,67. De daling is vooral het gevolg van het effectiever uitvoeren van taken die relatief onbelangrijk zijn. Het positieve verband wijst erop dat gemiddeld genomen werkenden en bedrijven het belang van de werktaak (een indicator voor de vraag) weten te koppelen aan de effectiviteit waarmee de werktaken worden uitgevoerd (een indicator voor het aanbod). Dit wijst erop dat er over het algemeen een goede match is tussen vraag en aanbod zoals gemeten met deze survey.

Wanneer de gemiddelde veranderingen in het belang van taken en de effectiviteit waarmee deze worden uitgevoerd tegen elkaar worden afgezet, ontstaat een wat diffuser beeld. Theoretisch is de verwachting dat als een werktaak aan belang wint, de effectiviteit ook hoger komt te liggen. Immers de gestelde eisen aan het werk nemen toe, waardoor de werkende meer zal moeten leveren. Figuur 3.3 geeft weer dat dit voor een aantal taken het geval is (het lezen en beoordelen van lange rapporten, brieven en memo's (taak 24), het maken van berekeningen met decimalen, percentages of fracties (taak 29) en het gebruik van wiskunde of statistiek om berekeningen te maken (taak30), maar dat er ook veel taken zijn die aan belang hebben gewonnen, maar niet effectiever worden uitgevoerd. Het omgekeerde geldt ook. Nu zijn de veranderingen in belang over het algemeen niet groot en meestal statistisch niet significant, waardoor het veranderende belang van taken moeilijk te interpreteren is. De grootste toename in effectiviteit is gemeten op het terrein van taken die te maken hebben met computergebruik en wiskunde. Dit is consistent met het algemene beeld dat analytische vaardigheden aan belang toenemen. Grote dalers zijn te zien op het terrein van kennis van producten en organisatie, wat consistent is met de toenemende codificatie van dit soort informatie in bedrijfsprocessen. 
FIGUUR 3.1

Gemiddeld belang afgezet tegen de gemiddelde effectiviteit (2012)

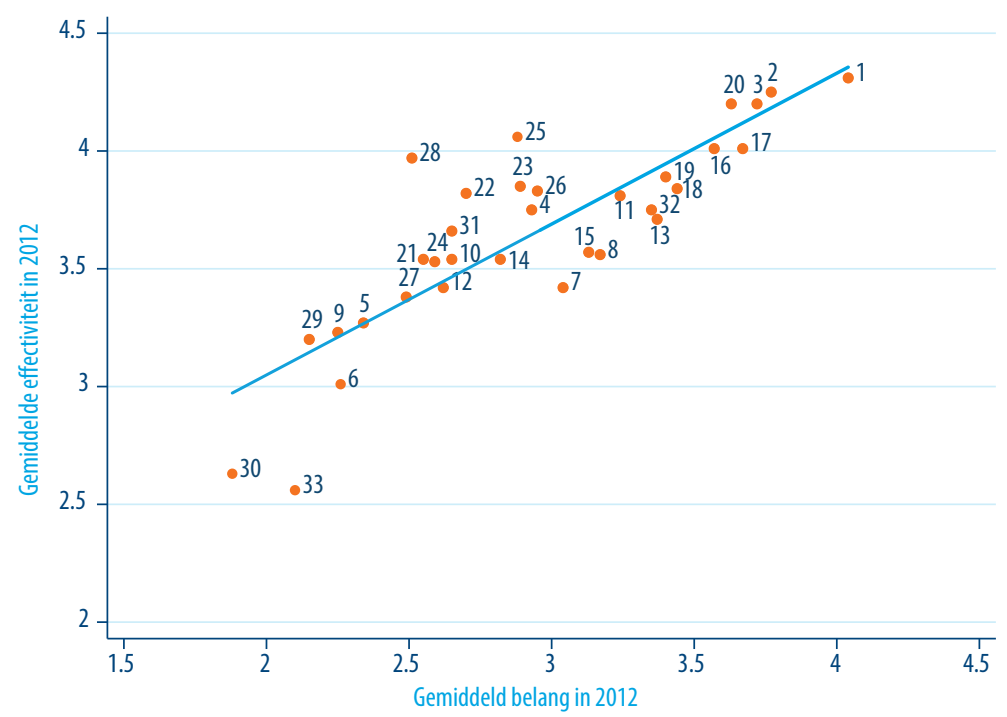

Bron: NSS 2012

FIGUUR 3.2

Gemiddeld belang afgezet tegen de gemiddelde effectiviteit (2017)

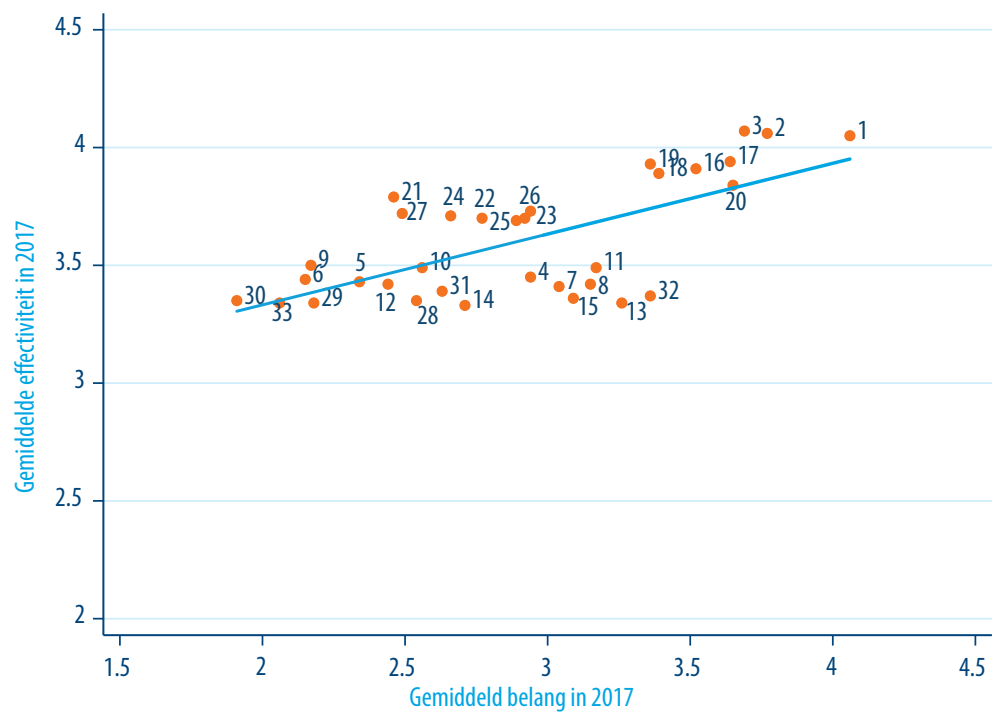

Bron: NSS 2017 


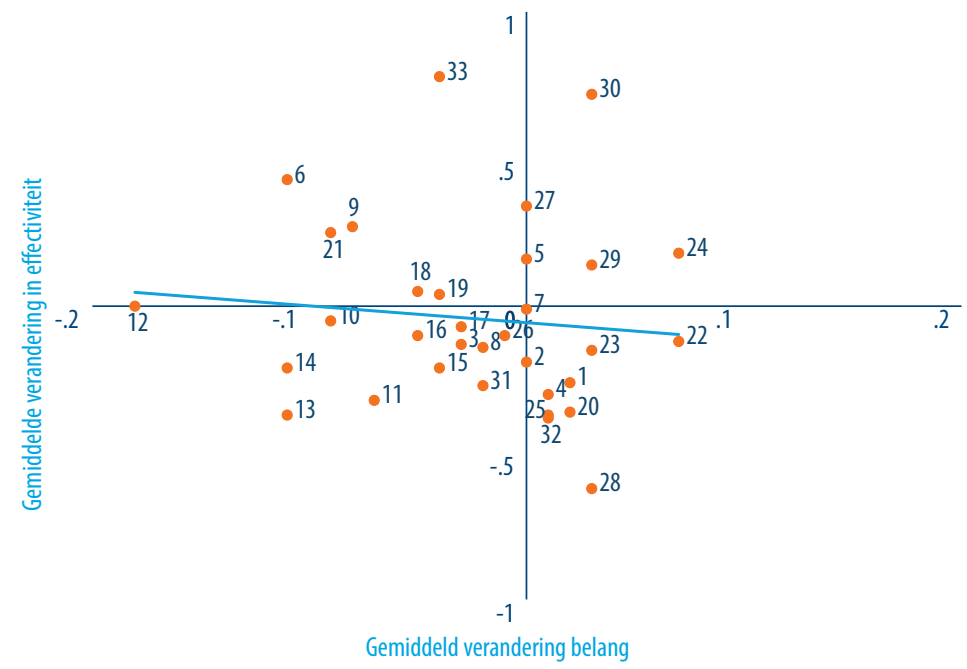

Bron: NSS 2012 en 2017

Een beperking van de surveydata is dat de schaal een maximum heeft (van 5). Dit betekent dat over de tijd gemeten taken die al erg belangrijk zijn of die al zeer effectief worden uitgevoerd niet meer aan belang of effectiviteit kunnen winnen. We hebben daarom in Figuur 3.4 en Figuur 3.5 het gemiddelde belang en de gemiddelde effectiviteit in 2012 op de horizontale as geplot. Hier zijn behoorlijke verschillen zichtbaar tussen de verschillende taken. Op de verticale as laten we de verandering in belang en effectiviteit in de periode 2012-2017 zien. De trendlijn geeft aan of sprake is van convergentie (dalende trendlijn), divergentie (stijgende trendlijn) of geen verband (horizontale trendlijn). Als we kijken naar het belang dan is er geen verband zichtbaar. Dit betekent dat taken die in 2012 gemiddeld gezien relatief onbelangrijk waren niet zijn ingelopen in belang op taken die in 2012 gemiddeld gezien al relatief belangrijk waren. Op het terrein van het gemiddelde belang van taken lijkt er dus weinig verandering zichtbaar, een beeld dat overeenkomt met de beschrijvende statistiek in de tabellen aan het begin van dit hoofdstuk. Voor de verandering in effectiviteit is echter een ander beeld zichtbaar. Taken die in 2012 gemiddeld minder effectief werden uitgevoerd zijn gemiddeld gezien de grootste stijgers in effectiviteit. Gegeven het maximum van de schaal, betekent dit dat de Nederlandse beroepsbevolking gemiddeld gezien effectiever is geworden in het uitvoeren van werktaken die minder effectief werden uitgevoerd in 2012. 
FIGUUR 3.4

Gemiddeld belang afgezet tegen de gemiddelde verandering in effectiviteit

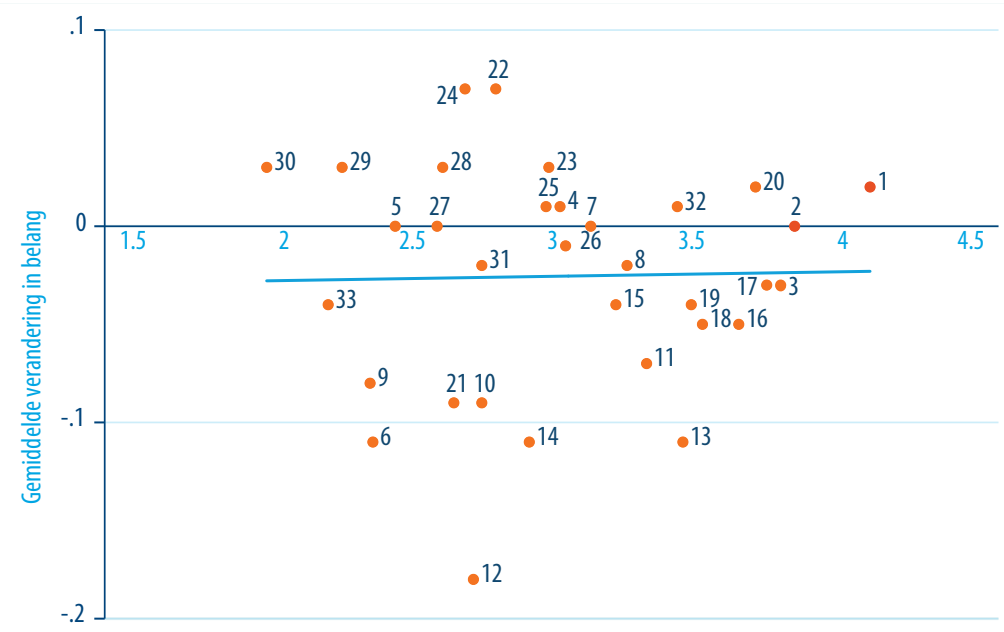

Gemiddeld belang in 2012

Bron: NSS 2012 en 2017

FIGUUR 3.5

Gemiddelde effectiviteit afgezet tegen de gemiddelde verandering in effectiviteit

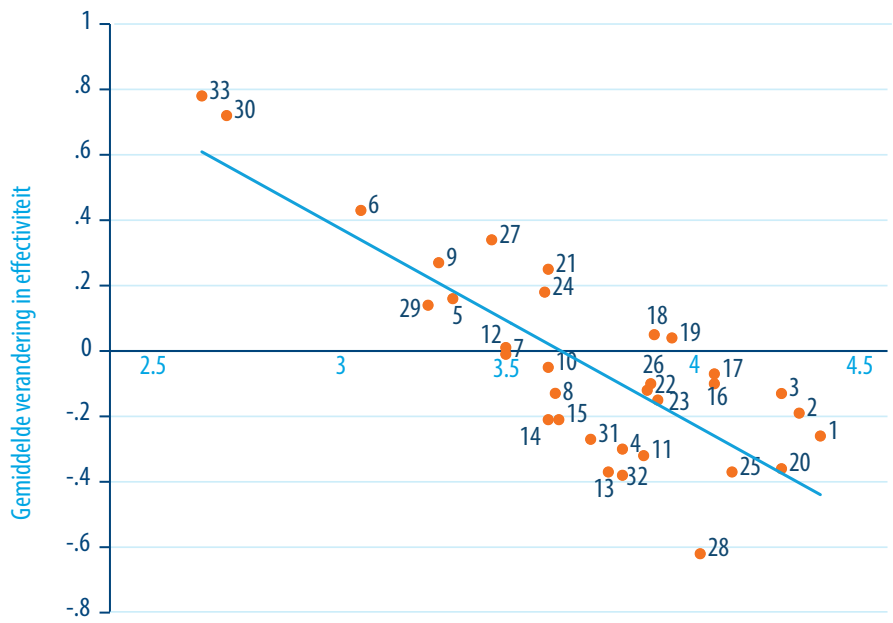

Gemiddelde effectiviteit in 2012 


\subsection{Belang en effectiviteit van samenhangende taken}

De lijst met taken, zoals gepresenteerd in de voorgaande paragraaf, is met specifieke kennis tot stand gekomen. De lijst bestaat namelijk uit clusters van taken die met elkaar samenhangen. Deze clustering is tot stand gekomen in de studies van Borghans et al. (2008 en 2014) waarin werktaken in Duitsland, het Verenigd Koninkrijk en de Verenigde Staten zijn geanalyseerd. Met behulp van factoranalyse is onderzocht of dezelfde clusters van taken naar voren komen in de NSS. Uit de factoranalyse blijkt dat de 33 individuele taken, waar in beide jaren van de NSS naar is gevraagd, kunnen worden geclusterd in acht categorieën van taken die grote samenhang vertonen. In Tabel 3.3 zijn de acht clusters met bijbehorende taken weergegeven. In de laatste kolom wordt de mate van samenhang gerapporteerd aan de hand van Cronbach's alfa. Een waarde van o,7 wordt in de literatuur gezien als een ondergrens. ${ }^{8}$

\section{TABEL 3.3}

Clustering van taken

\begin{tabular}{|l|l|l|}
\hline Vaardigheid & Geclusterde taken & Cronbach's alfa \\
\hline Interpersoonlijke vaardigheden & $1 \mathrm{t} / \mathrm{m} 8$ & 0,8030 \\
\hline Fysieke behendigheid & $9 \mathrm{t} / \mathrm{m} 11$ & 0,7540 \\
\hline Kennis van de organisatie & $12 \mathrm{t} / \mathrm{m} 15$ & 0,6599 \\
\hline Probleemoplossend vermogen & $16 \mathrm{t} / \mathrm{m} 19$ & 0,8871 \\
\hline Plannen en organiseren & $20 \mathrm{en} 21$ & 0,5605 \\
\hline Taalvaardigheden & $22 \mathrm{t} / \mathrm{m} 27$ & 0,9195 \\
\hline Rekenvaardigheden & $28 \mathrm{t} / \mathrm{m} \mathrm{30}$ & 0,8820 \\
\hline Computervaardigheden & $31 \mathrm{t} / \mathrm{m} \mathrm{33}$ & 0,6615 \\
\hline
\end{tabular}

Bron: NSS 2012 en 2017

\section{Correlaties tussen geclusterde taken}

De correlatie binnen de geclusterde taken is hoger dan tussen de geclusterde categorieën in beide jaren, met minimale verschillen tussen 2012 en 2017, wat laat zien dat deze werktaken bij elkaar horen (Tabel 3.4). Ook geldt dat de correlatie tussen het belang van taken lager is dan de correlatie tussen de effectiviteit van taken. Dat suggereert dat werkenden vaker meer taken effectief kunnen uitvoeren dan er in een beroep van belang zijn.

Gekeken naar de correlatie tussen het belang van taken, dan valt op dat fysieke behendigheid nauwelijks correleert met andere taken. Blijkbaar komt fysiek werk vaak voor in beroepen waarin andere taken minder belangrijk zijn. Verder komt naar voren dat

8 De alfa geeft aan dat bepaalde taken bij elkaar horen, maar zegt niets over de interne consistentie van een instrument of de factorstructuur. Wij gebruiken het om taken die een samenhang hebben als construct in de analyses op te kunnen nemen. 
computer- en rekenvaardigheden vaak hand-in-hand gaan. De correlatie tussen deze vaardigheden is namelijk het hoogst.

Uit de effectiviteit van taken blijkt dat werkenden die interpersoonlijke vaardigheden bezitten, vaak ook goed scoren op alle overige taken (Tabel 3.5). Datzelfde geldt over het algemeen ook voor taalvaardigheden, die alleen relatief laag correleren met fysieke behendigheid. Vaardigheden die de hoogste correlatie vertonen op effectiviteit zijn probleemoplossend vermogen en plannen en organiseren en - net zoals bij belang computer- en rekenvaardigheden.

TABEL 3.4

Correlatie tussen het belang van geclusterde taken

\begin{tabular}{|c|c|c|c|c|c|c|c|c|}
\hline Geclusterde taken & 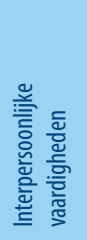 & 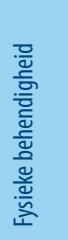 & 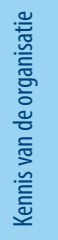 & 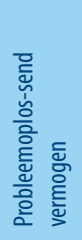 & 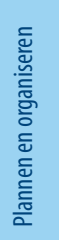 & 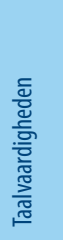 & 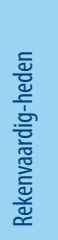 & 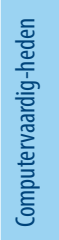 \\
\hline $\begin{array}{l}\text { Interpersoonlijke } \\
\text { vaardigheden }\end{array}$ & 1,00 & & & & & & & \\
\hline Fysieke behendigheid & 0,19 & 1,00 & & & & & & \\
\hline Kennis van de organisatie & 0,45 & 0,27 & 1,00 & & & & & \\
\hline $\begin{array}{l}\text { Probleemoplossend } \\
\text { vermogen }\end{array}$ & 0,47 & 0,18 & 0,60 & 1,00 & & & & \\
\hline Plannen en organiseren & 0,52 & 0,13 & 0,44 & 0,52 & 1,00 & & & \\
\hline Taalvaardigheden & 0,54 & 0,03 & 0,38 & 0,47 & 0,46 & 1,00 & & \\
\hline Rekenvaardigheden & 0,27 & $-0,00$ & 0,39 & 0,38 & 0,32 & 0,40 & 1,00 & \\
\hline Computervaardigheden & 0,38 & $-0,10$ & 0,42 & 0,41 & 0,38 & 0,53 & 0,61 & 1,00 \\
\hline
\end{tabular}

Bron: NSS 2012 en 2017 
TABEL 3.5

Correlatie tussen de effectiviteit van geclusterde taken

\begin{tabular}{|c|c|c|c|c|c|c|c|c|}
\hline Geclusterde taken & 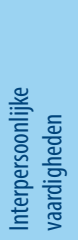 & 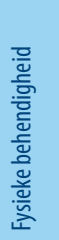 & 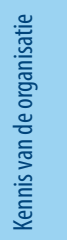 & 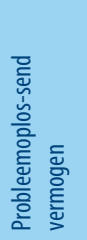 & 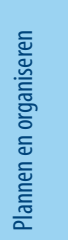 & 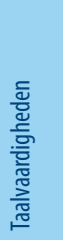 & 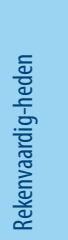 & 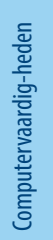 \\
\hline $\begin{array}{l}\text { Interpersoonlijke } \\
\text { vaardigheden }\end{array}$ & 1,00 & & & & & & & \\
\hline Fysieke behendigheid & 0,46 & 1,00 & & & & & & \\
\hline Kennis van de organisatie & 0,59 & 0,45 & 1,00 & & & & & \\
\hline $\begin{array}{l}\text { Probleemoplossend } \\
\text { vermogen }\end{array}$ & 0,62 & 0,40 & 0,65 & 1,00 & & & & \\
\hline Plannen en organiseren & 0,56 & 0,37 & 0,53 & 0,65 & 1,00 & & & \\
\hline Taalvaardigheden & 0,56 & 0,26 & 0,51 & 0,55 & 0,49 & 1,00 & & \\
\hline Rekenvaardigheden & 0,40 & 0,28 & 0,50 & 0,44 & 0,37 & 0,55 & 1,00 & \\
\hline Computervaardigheden & 0,42 & 0,21 & 0,51 & 0,42 & 0,37 & 0,59 & 0,66 & 1,00 \\
\hline
\end{tabular}

Bron: NSS 2012 en 2017

\section{Ontwikkeling in het belang en de effectiviteit van geclusterde taken}

Ook voor de geclusterde taken is het gemiddelde belang en de gemiddelde effectiviteit berekend en is er naar de absolute (Tabel 3.6) en relatieve (Tabel 3.7) ontwikkelingen tussen 2012 en 2017 gekeken. Probleemoplossend vermogen, interpersoonlijke vaardigheden en plannen en organiseren zijn de belangrijkste vaardigheden in 2012. In 2017 is dit nog steeds het geval. De gemiddelde effectiviteit van deze vaardigheden is ook relatief het hoogst in beide jaren.

Het aantal geclusterde taken waarbij sprake is van een ontwikkeling is beperkt. Vaardigheden waarvan het belang gemiddeld genomen is afgenomen, zowel absoluut als relatief, betreffen fysieke behendigheid en kennis van de organisatie. Voor kennis van de organisatie is ook de effectiviteit in absolute en relatieve zin gemiddeld afgenomen. De effectiviteit van interpersoonlijke en rekenvaardigheden zijn in absolute zin gemiddeld gedaald, maar niet in relatieve zin. Het tegenovergestelde geldt voor computervaardigheden. De effectiviteit van deze vaardigheden is in relatieve zin toegenomen, maar niet in absolute zin. 
TABEL 3.6

Absolute veranderingen in belang en effectiviteit

\begin{tabular}{|l|l|l|l|l|l|l|l|}
\hline & \multicolumn{4}{|c|}{ Absoluut belangi) } & \multicolumn{4}{c|}{ Absolute effectiviteit2) } \\
\hline & 2012 & 2017 & $\Delta^{3)}$ & 2012 & 2017 & $\Delta^{3)}$ \\
\hline Interpersoonlijke vaardigheden & 3,16 & 3,14 & n.s. & 3,72 & 3,67 & $*$ \\
\hline Fysieke behendigheid & 2,71 & 2,63 & $* *$ & 3,53 & 3,49 & n.s. \\
\hline Kennis van de organisatie & 2,98 & 2,88 & $* *$ & 3,56 & 3,36 & $* *$ \\
\hline Probleemoplossend vermogen & 3,52 & 3,48 & n.s. & 3,94 & 3,92 & n.s. \\
\hline Plannen en organiseren & 3,09 & 3,06 & n.s. & 3,87 & 3,82 & n.s. \\
\hline Taalvaardigheden & 2,75 & 2,78 & n.s. & 3,75 & 3,71 & n.s. \\
\hline Rekenvaardigheden & 2,18 & 2,21 & n.s. & 3,27 & 3,35 & $*$ \\
\hline Computervaardigheden & 2,70 & 2,68 & n.s. & 3,32 & 3,36 & n.s. \\
\hline
\end{tabular}

1) betreft het gemiddelde van een vijfpunt-Likertschaal, waarbij $1=$ helemaal niet belangrijk/niet van toepassing; $2=$ niet erg belangrijk; $3=$ redelijk belangrijk; $4=e r g$ belangrijk; $5=$ cruciaal

2) betreft het gemiddelde van een vijfpunt-Likertschaal, waarbij $1=$ bijna nooit; $5=$ altijd

3) betreft het significantieniveau van het verschil tussen 2017 en 2012, waarbij n.s.= niet significant verschillend van nul; ${ }^{*}=5 \%$-significant; ${ }^{* *}=1 \%$-significant

Bron: NSS 2012 en 2017

TABEL 3.7

Relatieve veranderingen in belang en effectiviteit

\begin{tabular}{|c|c|c|c|c|c|c|}
\hline \multirow[t]{2}{*}{ Geclusterde taken } & \multicolumn{3}{|c|}{ Relatief belang ${ }^{1)}$} & \multicolumn{3}{|c|}{ Relatieve effectiviteit ${ }^{2)}$} \\
\hline & 2012 & 2017 & $\Delta^{3)}$ & 2012 & 2017 & $\Delta^{3)}$ \\
\hline Interpersoonlijke vaardigheden & 1,08 & 1,08 & n.s. & 1,02 & 1,02 & n.s. \\
\hline Fysieke behendigheid & 0,93 & 0,91 & * & 0,97 & 0,97 & n.s. \\
\hline Kennis van de organisatie & 1,02 & 0,99 & $* *$ & 0,98 & 0,93 & $* *$ \\
\hline Probleemoplossend vermogen & 1,20 & 1,20 & n.s. & 1,08 & 1,09 & n.s. \\
\hline Plannen en organiseren & 1,05 & 1,05 & n.s. & 1,06 & 1,06 & n.s. \\
\hline Taalvaardigheden & 0,94 & 0,96 & n.s. & 1,03 & 1,03 & n.s. \\
\hline Rekenvaardigheden & 0,74 & 0,76 & n.s. & 0,90 & 0,93 & n.s. \\
\hline Computervaardigheden & 0,92 & 0,92 & n.s. & 0,91 & 0,93 & * \\
\hline
\end{tabular}

1) betreft het gemiddelde van een vijfpunt-Likertschaal, waarbij $1=$ helemaal niet belangrijk/niet van toepassing; $2=$ niet erg belangrijk; $3=$ redelijk belangrijk; $4=$ =erg belangrijk; $5=$ cruciaal

2) betreft het gemiddelde van een vijfpunt-Likertschaal, waarbij $1=$ bijna nooit;5=altijd

3) betreft het significantieniveau van het verschil tussen 2017 en 2012, waarbij n.s.= niet significant verschillend van nul; * $=5 \%$-significant; ${ }^{* *}=1 \%$-significant

Bron: NSS 2012 en 2017 
Voor alle werkenden in de NSS is het mogelijk om hun beroep vast te stellen volgens de classificatie van de Beroepenindeling ROA CBS 2014 (ROA/CBS, 2015). Er worden in totaal 114 beroepen onderscheiden, die allemaal vertegenwoordigd zijn in de NSS. Op basis van die classificatie is het mogelijk om kenmerken van werkenden te aggregeren op beroepsniveau. Eén van de kenmerken die we op beroepsniveau bekijken is het gemiddelde belang van een taak in een specifiek beroep. Hierbij zijn alleen beroepen meegenomen waarvan er minimaal 10 werkenden hebben meegedaan in de NSS. ${ }^{9}$ Voor de meeste taken ligt het maximale gemiddelde belang per beroep rond de vier (van een schaal van 1 tot 5). Daarop is één uitzondering, namelijk probleemoplossend vermogen waarvoor het gemiddelde belang in bepaalde beroepen ver boven de vier uitkomt. Dit is onder andere het geval voor managers productie en gebruikersondersteuning ICT. De beroepen die in de top 5 staan met hoogste belang verschillen per taak (zie Tabel 3.8). Beroepen waarbij veel sprake is van contact met mensen, zoals verschillende typen managers, scoren relatief hoog op het belang van interpersoonlijke vaardigheden. Beroepen die veel lichamelijke belasting vereisen, scoren relatief hoog op het belang van fysieke behendigheid. Deze uitkomsten zijn redelijk evident en worden door de NSS bevestigd. Wat ook uit de top 5 van beroepen met het hoogste belang van taken kan worden opgemaakt, is of bepaalde beroepen op meerdere taken in de top 5 staan. Dat is het geval voor managers (van winkels tot in de gezondheidszorg), die blijkbaar diverse taken moeten kunnen combineren. De complexiteit van het werk wordt nader behandeld in paragraaf 3.3.

Naast de top 5 beroepen met het hoogste belang is er ook gekeken naar de vijf beroepen per taak met het minste belang. Voor deze beroepen geldt eveneens dat ze verschillen per taak. Lassers hoeven bijvoorbeeld niet goed te zijn in taal- en computervaardigheden en voor schoonmakers is nauwelijks kennis van de organisatie en probleemoplossend vermogen een vereiste. Ook deze uitkomsten spreken redelijk voor zich.

Omdat de NSS in 2012 en 2017 is gehouden, is het mogelijk om naar ontwikkelingen per beroep te kijken ten aanzien van het belang van taken. Dit is echter alleen mogelijk voor beroepen met minstens 10 respondenten in iedere afzonderlijke NSS-meting. Dit betreft in totaal 57 beroepen. Voor medewerkers in de verzorging (verzorgenden/artsen) en laders en lossers zijn veel geclusterde taken in belang toegenomen (zie Tabel 3.9). Deze beroepen zijn tussen 2012 en 2017 complexer geworden. Daartegenover staan een aantal beroepen waarvoor de werkzaamheden minder complex zijn geworden, namelijk dat van hoveniers, tuinders en kwekers en bedieners van mobiele machines.

9 Hierdoor vallen 16 beroepen weg. 
TABEL 3.8

Top 5 beroepen met hoogste en laagste belang per geclusterde taak

\begin{tabular}{|c|c|c|c|}
\hline \multicolumn{2}{|c|}{ Top 5 beroepen met hoogste belang } & \multicolumn{2}{|c|}{ Top 5 beroepen met laagste belang } \\
\hline Score & Beroep & Score & Beroep \\
\hline \multicolumn{4}{|c|}{ Interpersoonlijke vaardigheden } \\
\hline 4,03 & Managers zorginstellingen & 2,09 & Veetelers \\
\hline 3,76 & $\begin{array}{l}\text { Docenten beroepsgerichte vakken secundair } \\
\text { onderwijs }\end{array}$ & 2,12 & Metaalbewerkers en constructiewerkers \\
\hline 3,74 & Managers ICT & 2,14 & Land- en bosbouwers \\
\hline 3,74 & Specialisten personeels- en loopbaanontwikkeling & 2,18 & Lassers en plaatwerkers \\
\hline 3,74 & Managers verkoop en marketing & 2,24 & Vuilnisophaler en dagbladenbezorgers \\
\hline \multicolumn{4}{|c|}{ Fysieke behendigheid } \\
\hline 3,69 & Bouwarbeiders afbouw & 1,94 & Managers ICT \\
\hline 3,67 & Fotografen en interieurontwerpers & 2,05 & Journalisten \\
\hline 3,61 & Kelners en barpersoneel & 2,06 & Boekhoudkundig medewerkers \\
\hline 3,59 & Hoveniers, tuinders en kwekers & 2,07 & Software- en applicatieontwikkelaars \\
\hline 3,56 & Bouwarbeiders ruwbouw & 2,07 & Juristen \\
\hline \multicolumn{4}{|c|}{ Kennis van de organisatie } \\
\hline 3,60 & Managers productie & 2,03 & Vuilnisophalers en dagbladenbezorgers \\
\hline 3,59 & Productieleiders industrie en bouw & 2,07 & Schoonmakers \\
\hline 3,55 & Databank- en netwerkspecialisten & 2,18 & Leidsters kinderopvang en onderwijsassistenten \\
\hline 3,53 & Militaire beroepen & 2,20 & Auteurs en taalkundigen \\
\hline 3,53 & Elektriciens en elektronicamonteurs & 2,43 & Sociaal werkers, groeps- en woonbegeleiders \\
\hline \multicolumn{4}{|c|}{ Probleemoplossend vermogen } \\
\hline 4,60 & Managers productie & 2,37 & Schoonmakers \\
\hline 4,28 & Gebruikersondersteuning ICT & 2,68 & Vuilnisophalers en dagbladenbezorgers \\
\hline 4,16 & Accountants & 2,77 & Chauffeurs auto's, taxi's en bestelwagens \\
\hline 4,12 & Databank- en netwerkspecialisten & 2,80 & Reisbegeleiders \\
\hline 4,12 & Juristen & 2,87 & Fotografen en interieurontwerpers \\
\hline \multicolumn{4}{|c|}{ Plannen en organiseren } \\
\hline 4,03 & Managers productie & 2,07 & Reisbegeleiders \\
\hline 3,97 & Managers ICT & 2,22 & Bedieners mobiele machines \\
\hline 3,86 & Managers onderwijs & 2,30 & Hulpkrachten bouw en industrie \\
\hline 3,78 & Managers verkoop en marketing & 2,38 & Schoonmakers \\
\hline 3,75 & $\begin{array}{l}\text { Managers zakelijke en administratieve } \\
\text { dienstverlening }\end{array}$ & 2,38 & Machinemonteurs \\
\hline \multicolumn{4}{|c|}{ Taalvaardigheden } \\
\hline 3,65 & Accountants & 1,22 & Vuilnisophalers en dagbladenbezorgers \\
\hline 3,62 & Managers zorginstellingen & 1,44 & Reisbegeleiders \\
\hline
\end{tabular}




\begin{tabular}{|l|l|l|l|}
\hline 3,56 & Biologen en natuurwetenschappers & 1,47 & Lassers en plaatwerkers \\
\hline 3,56 & Managers verkoop en marketing & 1,59 & Metaalbewerkers en constructiewerkers \\
\hline 3,52 & Beleidsadviseurs & 1,63 & Meubelmakers, kleermakers en stoffeerders \\
\hline $\begin{array}{l}\text { Rekenvaardigheden } \\
\text { 3,65 }\end{array}$ & Accountants & 1,10 & Reisbegeleiders \\
\hline 3,31 & Ingenieurs (geen elektrotechniek) & 1,33 & Journalisten \\
\hline 3,31 & Boekhouders & 1,35 & Leidsters kinderopvang en onderwijsassistenten \\
\hline 3,25 & Managers logistiek & 1,43 & Sociaal werkers, groeps- en woonbegeleiders \\
\hline 3,20 & Managers productie & 1,43 & Vuilnisophalers en dagbladbezorgers \\
\hline Computervaardigheden & & \\
\hline 3,74 & Managers ICT & 1,14 & Reisbegeleiders \\
\hline 3,62 & Boekhouders & 1,20 & Lassers en plaatbewerkers \\
\hline 3,58 & Managers verkoop en marketing & 1,50 & Bedieners en mobiele machines \\
\hline 3,57 & Accountants & 1,52 & Hulpkrachten bouw en industrie \\
\hline 3,55 & Financieel specialisten en economen & 1,56 & Schoonmakers \\
\hline B & &
\end{tabular}

Bron: NSS 2012 en 2017 
TABEL 3.9

Top 5 beroepen met grootste stijging en grootste daling in belang per geclusterde taak

\begin{tabular}{|c|c|c|c|}
\hline \multicolumn{2}{|c|}{ Top 5 beroepen met grootste stijging in belang } & \multicolumn{2}{|c|}{ Top 5 beroepen met grootste daling in belang } \\
\hline Score & Beroep & Score & Beroep \\
\hline \multicolumn{4}{|c|}{ Interpersoonlijke vaardigheden } \\
\hline$+11 \%$ & Verzorgenden & $-21 \%$ & Hoveniers, tuinders en kwekers \\
\hline$+10 \%$ & Laders, lossers en vakkenvullers & $-17 \%$ & Bedieners mobiele machines \\
\hline$+7 \%$ & Beleidsadviseurs & $-17 \%$ & Leidsters kinderopvang en onderwijsassistenten \\
\hline$+6 \%$ & Apothekersassistenten & $-11 \%$ & Elektriciens en elektronicamonteurs \\
\hline$+6 \%$ & Medewerkers drukkerij en kunstnijverheid & $-10 \%$ & Kappers en schoonheidsspecialisten \\
\hline \multicolumn{4}{|c|}{ Fysieke behendigheid } \\
\hline$+14 \%$ & Docenten algemene vakken secundair onderwijs & $-21 \%$ & Leidsters kinderopvang en onderwijsassistenten \\
\hline$+12 \%$ & $\begin{array}{l}\text { Callcentermedewerkers outbound en overige } \\
\text { verkopers }\end{array}$ & $-19 \%$ & Zakelijke dienstverlening \\
\hline$+11 \%$ & Psychologen en sociologen & $-14 \%$ & Databank- en netwerkspecialisten \\
\hline$+11 \%$ & Financieel specialisten en economen & $-14 \%$ & Bedieners mobiele machines \\
\hline$+10 \%$ & Algemeen directeuren & $-11 \%$ & Overheidsambtenaren \\
\hline \multicolumn{4}{|c|}{ Kennis van de organisatie } \\
\hline$+17 \%$ & Docenten algemene vakken secundair onderwijs & $-23 \%$ & Hoveniers, tuinders en kwekers \\
\hline$+13 \%$ & Juristen & $-21 \%$ & Bedieners mobiele machines \\
\hline$+13 \%$ & Laders, lossers en vakkenvullers & $-16 \%$ & Kelners en barpersoneel \\
\hline$+9 \%$ & Maatschappelijk werkers & $-15 \%$ & Beveiligingspersoneel \\
\hline$+9 \%$ & Financieel specialisten en economen & $-15 \%$ & Leerkrachten basisonderwijs \\
\hline \multicolumn{4}{|c|}{ Probleemoplossend vermogen } \\
\hline$+27 \%$ & Laders, lossers en vakkenvullers & $-23 \%$ & Bedieners mobiele machines \\
\hline$+11 \%$ & Apothekersassistenten & $-19 \%$ & Leidsters kinderopvang en onderwijsassistenten \\
\hline$+8 \%$ & Zakelijke dienstverleners & $-16 \%$ & Kelners en barpersoneel \\
\hline$+8 \%$ & $\begin{array}{l}\text { Managers zakelijke en administratieve } \\
\text { dienstverlening }\end{array}$ & $-15 \%$ & Kappers en schoonheidsspecialisten \\
\hline$+7 \%$ & Vertegenwoordigers en inkopers & $-14 \%$ & Hoveniers, tuinders en kwekers \\
\hline \multicolumn{4}{|c|}{ Plannen en organiseren } \\
\hline$+15 \%$ & Laders, lossers en vakkenvullers & $-23 \%$ & Politie en brandweer \\
\hline$+13 \%$ & Artsen & $-19 \%$ & Kelners en barpersoneel \\
\hline$+10 \%$ & Financieel specialisten en economen & $-19 \%$ & Vrachtwagenchauffeurs \\
\hline$+10 \%$ & Psychologen en sociologen & $-18 \%$ & Hoveniers, tuinders en kwekers \\
\hline$+10 \%$ & Zakelijke dienstverleners & $-18 \%$ & Bedieners mobiele machines \\
\hline \multicolumn{4}{|c|}{ Taalvaardigheden } \\
\hline$+33 \%$ & Juristen & $-37 \%$ & Hoveniers, tuinders en kwekers \\
\hline$+26 \%$ & Laders, lossers en vakkenvullers & $-25 \%$ & Medewerkers drukkerij en kunstnijverheid \\
\hline
\end{tabular}




\begin{tabular}{|l|l|l|l|}
\hline$+22 \%$ & Docenten hoger onderwijs en hoogleraren & $-22 \%$ & Bedieners mobiele machines \\
\hline$+21 \%$ & Verzorgenden & $-19 \%$ & Beveiligingspersoneel \\
\hline$+12 \%$ & Boekhoudkundig medewerkers & $-19 \%$ & Leidsters kinderopvang en onderwijsassistenten \\
\hline Rekenvaardigheden & & \\
\hline$+28 \%$ & Kappers en schoonheidsspecialisten & $-38 \%$ & Hoveniers, tuinders en kwekers \\
\hline$+25 \%$ & Laders, lossers en vakkenvullers & $-30 \%$ & Docenten hoger onderwijs en hoogleraren \\
\hline$+24 \%$ & Managers zakelijke en administratieve & $-24 \%$ & Kelners en barpersoneel \\
\hline$+23 \%$ & Verzorgenden & $-21 \%$ & Beveiligingspersoneel \\
\hline$+20 \%$ & Timmerlieden & $-17 \%$ & Medewerkers drukkerij en kunstnijverheid \\
\hline Computervaardigheden & & \\
\hline$+29 \%$ & Laders, lossers en vakkenvullers & $-28 \%$ & Bedieners mobiele machines \\
\hline$+25 \%$ & Verzorgenden & $-19 \%$ & Beveiligingspersoneel \\
\hline$+13 \%$ & Artsen & $-18 \%$ & Timmerlieden \\
\hline$+12 \%$ & Specialisten personeels- en loopbaanontwikkeling & $-16 \%$ & Hoveniers, tuinders en kwekers \\
\hline$+10 \%$ & Zakelijke dienstverleners & $-15 \%$ & Politie en brandweer \\
\hline
\end{tabular}

Bron: NSS 2012 en 2017

\section{Ontwikkeling in belang en effectiviteit bij gewijzigd en ongewijzigd beroep}

De groep werkenden die in 2012 heeft deelgenomen aan de NSS lijkt qua samenstelling sterk op de groep werkenden die in 2017 heeft deelgenomen. Op basis van analyses op beide afzonderlijke jaren zijn uitspraken gedaan over de ontwikkeling in het belang en de effectiviteit van de geclusterde taken voor een gemiddelde Nederlandse werknemer (zie hierboven). Met behulp van de data is het ook mogelijk om een uitspraak te doen over de ontwikkelingen van werkenden die in beide jaren hebben deelgenomen. Dit betreft een groep van in totaal 1.126 werkenden, van wie ongeveer de helft nog hetzelfde beroep uitoefent ( $n=597$, zie Tabel 3.10).

Voor zowel de werkenden die van beroep zijn veranderd als voor degenen met een ongewijzigd beroep, zijn hun antwoorden in 2012 en 2017 met betrekking tot het belang en de effectiviteit onderling vergeleken. Voor alle clusters van taken zijn voor beide groepen geen significante verschillen gevonden met betrekking tot het belang van werktaken. Dit kan echter te maken hebben met het relatief lage aantal werkenden op wie de analyses is gebaseerd, maar past tevens in het beeld dat er in termen van het belang van werktaken weinig verandering is waargenomen.

Ten aanzien van effectiviteit zijn drie significante verschillen zichtbaar tussen de groep werkenden die van baan is veranderd en de groep die nog hetzelfde beroep heeft. Het eerste verschil heeft betrekking op kennis van de organisatie. Werkenden die niet van beroep zijn veranderd zijn hierin gemiddeld sterker gedaald dan werkenden die 
wel van beroep zijn veranderd. Dit zou erop kunnen wijzen dat mensen in beroepen waarin kennis van de organisatie in belang afneemt vaker mobiel zijn richting beroepen waarin dit wel van belang is. Werkenden die in hun baan blijven zitten, moeten zich vervolgens aanpassen. Datzelfde geldt ook voor de effectiviteit in taalvaardigheden. Het derde verschil heeft betrekking op de effectiviteit in rekenvaardigheden. Werkenden die hetzelfde beroep hebben zijn gemiddeld minder effectief geworden in rekenvaardigheden, terwijl werkenden die van baan zijn veranderd er juist effectiever in zijn geworden. Kennelijk vereist hun nieuwe beroep dit ook meer, gegeven het toegenomen gemiddelde belang van dit soort analytische werkzaamheden. Deze observatie past in de tendens dat analytische vaardigheden gemiddeld gezien belangrijker worden. In hoofdstuk 5 komen we terug op de relatie tussen loopbaanstappen en het belang van taken en de taakeffectiviteit.

\section{TABEL 3.10}

Ontwikkelingen in taken vergeleken tussen werkenden met een gewijzigd en ongewijzigd beroep tussen 2012 en 2017

\begin{tabular}{|c|c|c|c|c|c|c|}
\hline \multirow{2}{*}{$\begin{array}{l}\text { Verandering tussen } 2012 \text { en } 2017 \text { in geclusterde taken } \\
\text { Geclusterde taken }\end{array}$} & \multicolumn{3}{|c|}{ Belang1) } & \multicolumn{3}{|c|}{ Effectiviteit ${ }^{2)}$} \\
\hline & 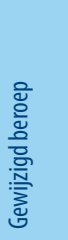 & 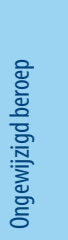 & $\Delta^{3)}$ & 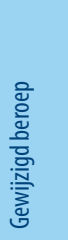 & 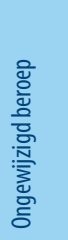 & $\Delta^{3)}$ \\
\hline Interpersoonlijke vaardigheden & $-0,07$ & $-0,08$ & n.s. & $-0,05$ & $-0,08$ & n.s. \\
\hline Fysieke behendigheid & $-0,01$ & $-0,05$ & n.s. & $-0,01$ & $-0,08$ & n.s. \\
\hline Kennis van de organisatie & $-0,13$ & $-0,14$ & n.s. & $-0,15$ & $-0,36$ & *** \\
\hline Probleemoplossend vermogen & $-0,07$ & $-0,13$ & n.s. & 0,01 & $-0,06$ & n.s. \\
\hline Plannen en organiseren & $-0,13$ & $-0,11$ & n.s. & $-0,09$ & $-0,12$ & n.s. \\
\hline Taalvaardigheden & $-0,01$ & $-0,03$ & n.s. & 0,00 & $-0,13$ & ** \\
\hline Rekenvaardigheden & 0,03 & $-0,07$ & n.s. & 0,14 & $-0,05$ & *** \\
\hline Computervaardigheden & $-0,05$ & $-0,13$ & n.s. & $-0,04$ & $-0,09$ & n.s. \\
\hline
\end{tabular}

1) betreft het gemiddelde van een vijfpunt-Likertschaal, waarbij $1=$ helemaal niet belangrijk/niet van toepassing; $2=$ niet erg belangrijk; $3=$ redelijk belangrijk; $4=$ =erg belangrijk; $5=$ cruciaal

2) betreft het gemiddelde van een vijfpunt-Likertschaal, waarbij $1=$ bijna nooit; $5=$ altijd

3) betreft het significantieniveau van het verschil tussen 2017 en 2012, waarbij n.s. = niet significant verschillend van nul; ${ }^{*}=5 \%$-significant; ${ }^{* *}=1 \%$-significant

Bron: NSS 2012 en 2017

\section{Samenhang tussen persoonskenmerken en de effectiviteit van geclusterde taken}

De mate waarin werkenden effectief zijn in het uitvoeren van taken zou kunnen samenhangen met hun persoonskenmerken. Om dat te onderzoeken is een regressieanalyse uitgevoerd, waarbij de effectiviteit van een bepaalde taak $t$ voor werkende $i\left(E_{i, t}\right)$ wordt 
verklaard door de persoonskenmerken geslacht, leeftijd en opleidingsniveau $\left(X_{i, t}\right)$ met correcties voor het beroepssegment waarin iemand werkzaam is en geclusterde standaardfouten voor werkenden die in beide jaren van de NSS hebben geparticipeerd. De vergelijking ziet er als volgt uit:

$$
E_{i, t}=\alpha+\beta X_{i, t}+\mu
$$

Deze vergelijking is per taak een keer zonder (vergelijking a in Tabel 3.11) en een keer met correctie voor het belang van de taak (vergelijking $b$ in Tabel 3.11) geschat.

Uit de regressieanalyses blijkt dat de persoonskenmerken geslacht, leeftijd en opleidingsniveau een belangrijke rol spelen in het verklaren van de effectiviteit van de geclusterde taken van werkenden. Vrouwen schatten hun effectiviteit lager in dan mannen bij zes van de acht geclusterde taken. ${ }^{10}$ Deze uitkomst is robuust voor het wel of niet corrigeren voor het belang van een geclusterde taak. Het grootste verschil tussen mannen en vrouwen heeft betrekking op taken gerelateerd aan rekenvaardigheden, het kleinste verschil op taken gerelateerd aan interpersoonlijke vaardigheden. De twee geclusterde taken waarin mannen en vrouwen even effectief zijn, betreft plannen en organiseren en taalvaardigheden.

Ook bestaat er een duidelijk verband tussen de leeftijd van werkenden en de effectiviteit van geclusterde taken. Dat verband is over het algemeen negatief en eveneens robuust voor het corrigeren voor het belang van taken: oudere werkenden schatten hun eigen effectiviteit lager in dan jongeren. Dit geldt het sterkst voor computervaardigheden en fysieke behendigheid.

Voor het opleidingsniveau van werkenden geldt het tegenovergestelde als voor leeftijd: hoger opgeleiden schatten hun taakeffectiviteit hoger in dan laagopgeleiden voor de meeste taken. Daarbij is het opleidingsniveau ingedeeld in drie categorieën, namelijk laag, middelbaar en hoog. Laag staat voor afgerond basisonderwijs of voortgezet middelbaar beroepsonderwijs (vmbo), gemiddeld voor havo, vwo of mbo en hoog voor alle vormen van hoger onderwijs. Bij zes van de acht geclusterde taken zijn hoger opgeleiden significant effectiever dan laagopgeleiden en in de meeste gevallen ook dan de middelbaar opgeleiden. Hoger opgeleiden zijn echter minder effectief in het uitvoeren van taken waarbij fysieke behendigheid vereist is. Voor plannen en organiseren is geen significant verband aangetoond tussen opleidingsniveau en effectiviteit.

10 Borghans en Golsteyn (2013) hebben de validiteit van de meting van het belang van taken en de effectiviteit onderzocht door middel van een vignetanalyse waarbij ze de antwoorden van respondenten herijken aan het beroep van werkenden. Door verschillen naar geslacht te vergelijken voor en na herijking laten zij zien dat mannen en vrouwen andere schalen hanteren bij het beantwoorden van vragen over het belang van taken op het werk. Het herijken van antwoorden heeft echter geen grote gevolgen voor de gemeten verschillen in gerapporteerde effectiviteit tussen mannen en vrouwen. 


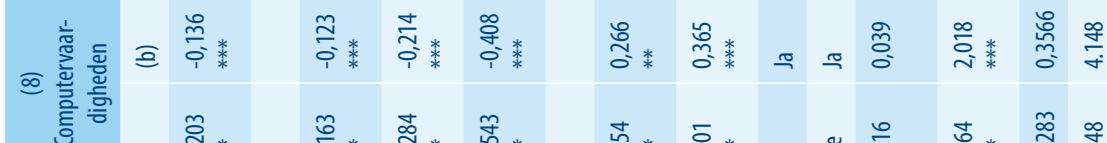

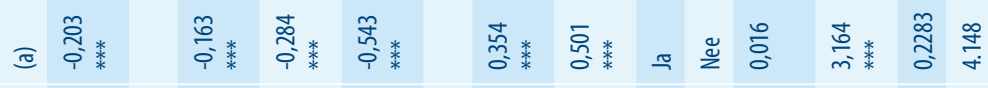

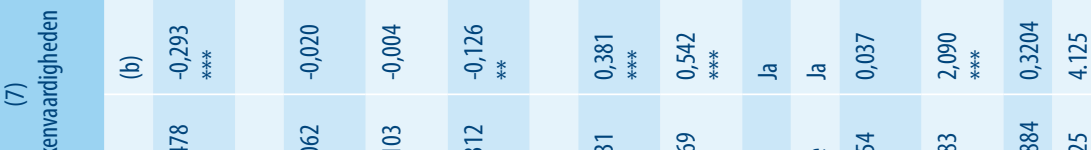

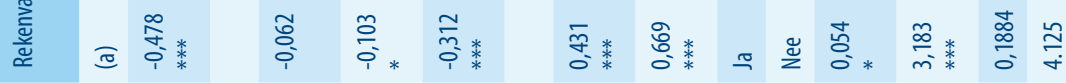

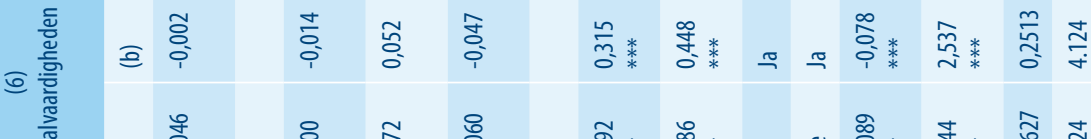

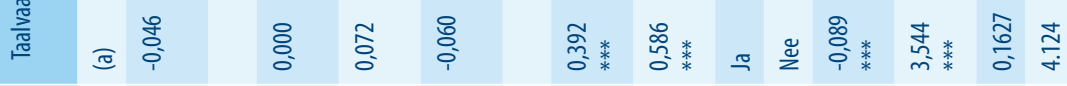

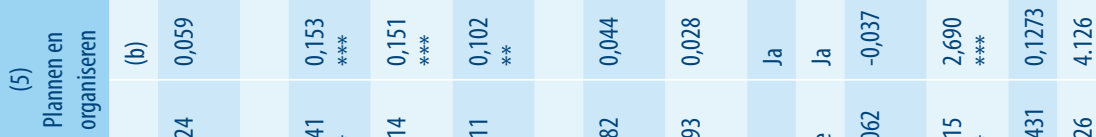

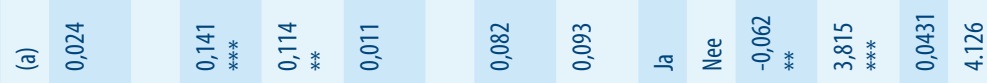

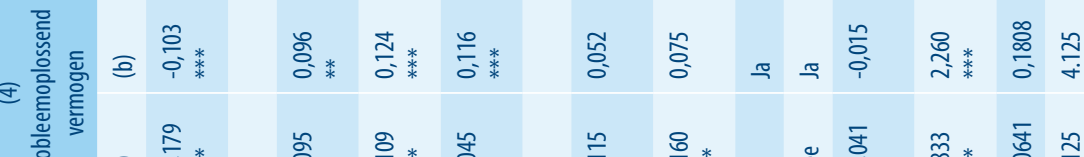

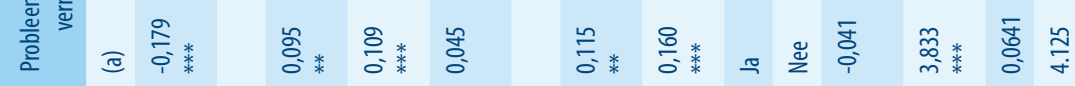

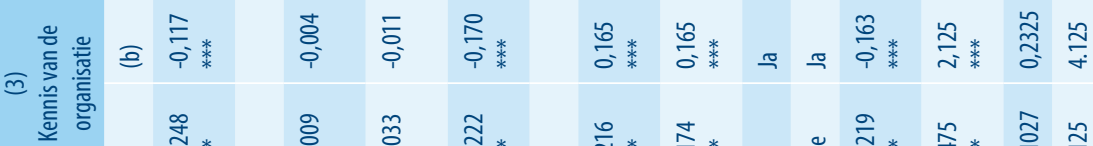

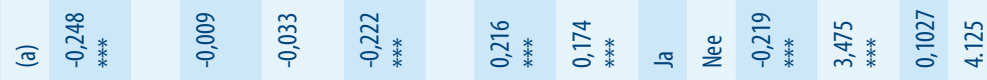

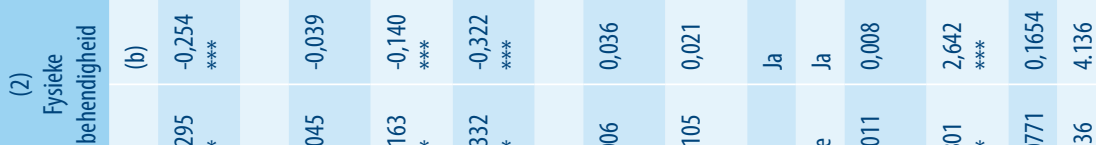

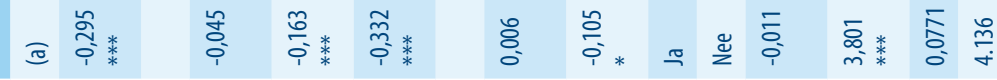

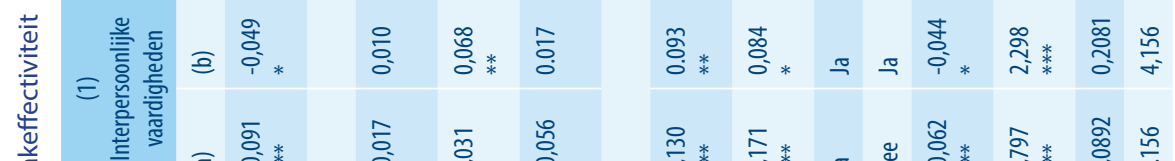

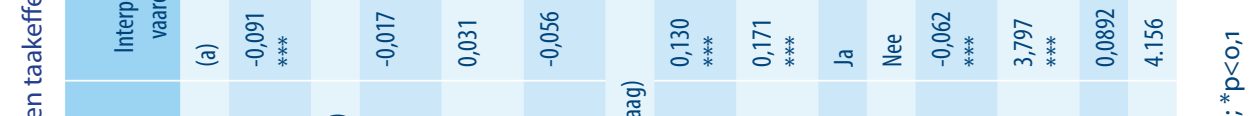

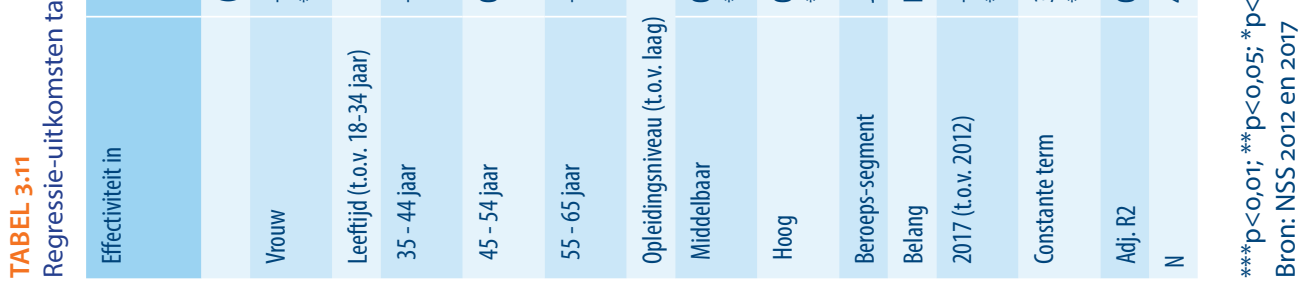


Interessant is om te onderzoeken of de mate waarin werkenden effectief zijn in het uitvoeren van taken op het werk bepalend is voor het loon dat ze verdienen. Daartoe is een regressieanalyse uitgevoerd op het bruto uurloon dat werkenden verdienen. Deze analyse is conditioneel op de match en de keuzes die mensen hebben gemaakt, waardoor selectie-effecten een rol spelen. Een strikt causale interpretatie is daarom niet mogelijk.

Het bruto uurloon (HWAGE) van een werkende $i$ (in log) in jaar t wordt verklaard door middel van de persoonskenmerken geslacht en leeftijd $(X)$ en de effectiviteit van de acht geclusterde vaardigheden $\left(E_{i, t}\right)$. De specificatie van de regressievergelijking ziet er als volgt uit:

$$
\log H W A G E_{i, t}=\alpha+\beta X_{i, t}+\gamma E_{i, t}+\mu
$$

Bovenstaande regressievergelijking wordt op twee manier geschat. Allereerst als gepoolde OLS met robuuste standaardfouten. Daarbij schatten we vijf verschillende specificaties (i-v in Tabel 3.12), waarbij steeds extra controlevariabelen van werkenden aan de vergelijking zijn toegevoegd. Dit betreft het opleidingsniveau van werkenden, het belang van de taken, het beroepssegment en of er in deeltijd wordt gewerkt. Daarnaast benutten we de panelstructuur van de NSS en schatten we een fixed-effect model. Met dit model schakelen we de niet-waargenomen kenmerken van werkenden uit die mogelijk bepalend zijn voor het loon, om daarmee zuiverdere causale verbanden vast te stellen. Dit model is een keer zonder en een keer met correctie voor het belang van taken gedraaid.

Uit de gepoolde OLS-regressieanalyse blijkt dat het loon van werkenden vooral wordt bepaald door de leeftijd, het opleidingsniveau en het geslacht van werkenden. Hoe effectief werkenden zijn in het uitvoeren van taken heeft een klein effect op het loon. Wel zijn er op basis van deze analyse taken aan te wijzen die correleren met een hoger of lager loon als de effectiviteit in die taken toeneemt. Effectiever worden in interpersoonlijke vaardigheden, fysieke behendigheid, kennis van de organisatie, plannen en organiseren en computervaardigheden correleren met een lager loon. Daarentegen correleert een verbeterde effectiviteit in probleemoplossend vermogen, taalvaardigheden en rekenvaardigheden positief met het salaris. Voor probleemoplossend vermogen en taalvaardigheden is bovendien een statistisch significant positief verband aangetoond, dat robuust is voor het type vergelijking.

Het fixed-effect model (Tabel 3.13) komt voor zes van de acht geclusterde taken tot dezelfde uitkomsten als de gepoolde OLS-regressie. Het verschil zit in de interpersoonlijke en taalvaardigheden. Een verbetering in effectiviteit van interpersoonlijke vaardigheden leidt volgens het fixed-effect model tot een hoger loon en volgens de gepoolde OLS-regressie tot een lager loon. In beide modellen is het verband ook statistisch significant aangetoond. Voor taalvaardigheden geldt exact het tegenovergestelde: volgens het fixed-effect model leidt een verbetering van de effectiviteit in taalvaardigheden tot een lager loon en volgens de gepoolde OLS-regressie tot een hoger loon. 
TABEL 3.12

Schattingsuitkomsten loonregressies (gepoolde OLS)

\begin{tabular}{|c|c|c|c|c|}
\hline & (i) & (ii) & (iii) & (iv) \\
\hline Interpersoonlijke vaardigheden & $0,042^{* * *}$ & $-0,016$ & $-0,013$ & $-0,012$ \\
\hline Fysieke behendigheid & $-0,066^{* * *}$ & $-0,019^{* * *}$ & $-0,013^{* *}$ & $-0,009$ \\
\hline Kennis van de organisatie & $-0,024^{* *}$ & $-0,010$ & $-0,002$ & $-0,004$ \\
\hline Probleemoplossend vermogen & $0,022^{* * *}$ & $0,026^{* *}$ & $0,026^{* *}$ & $0,028^{* * *}$ \\
\hline Plannen en organiseren & $-0,010$ & $-0,011$ & $-0,003$ & $-0,003$ \\
\hline Taalvaardigheden & $0,084^{* * *}$ & $0,048^{* * *}$ & $0,029^{* * *}$ & $0,024^{* * *}$ \\
\hline Rekenvaardigheden & $0,023^{* * *}$ & $0,027^{* * *}$ & $0,013^{*}$ & 0,012 \\
\hline Computervaardigheden & 0,004 & $-0,010$ & $-0,013^{*}$ & $-0,015^{*}$ \\
\hline Vrouw (t.o.v. man) & $-0,137^{* * *}$ & $-0,139 * * *$ & $-0,137^{* * *}$ & $-0,106^{* * *}$ \\
\hline Leeftijd 35-44 (t.o.v. 18-34) & $0,180^{* * *}$ & $0,190^{* * *}$ & $0,227^{* * *}$ & $0,218^{* * *}$ \\
\hline Leeftijd 45-54 (t.o.v. 18-34) & $0,187^{* * *}$ & $0,210^{* * *}$ & $0,266^{* * *}$ & $0,250^{* * *}$ \\
\hline Leeftijd 55-66 (t.o.v. 18-34) & $0,299 * * *$ & $0,329^{* * *}$ & $0,375^{* * *}$ & $0,353^{* * *}$ \\
\hline Middelbaar opgeleid (t.o.v. laag) & & & $0,090^{* * *}$ & $0,058^{* * *}$ \\
\hline Hoog opgeleid (t.o.v. laag) & & & $0,330^{* * *}$ & $0,231^{* * *}$ \\
\hline \multicolumn{5}{|l|}{ Deeltijd werk (t.o.v. fulltime) } \\
\hline Jaar 2017 & $0,080^{* * *}$ & $0,068^{* * *}$ & $0,055^{* * *}$ & $0,059^{* * *}$ \\
\hline Belang van taken & Nee & $\mathrm{Ja}$ & $\mathrm{Ja}$ & $\mathrm{Ja}$ \\
\hline Beroepssegment & Nee & Nee & Nee & $\mathrm{Ja}$ \\
\hline Constant & $2,486^{* * *}$ & $2,437^{* * *}$ & $2,339^{* * *}$ & $2,487^{* * *}$ \\
\hline R2 & 0,2033 & 0,2748 & 0,3548 & 0,4136 \\
\hline $\mathrm{N}$ & 3.659 & 3.659 & 3.657 & 3.431 \\
\hline
\end{tabular}


TABEL 3.13

Schattingsresultaten loonregressie (panel fixed-effects)

\begin{tabular}{|c|c|c|}
\hline Verandering in de effectiviteit van... & (i) & (ii) \\
\hline Interpersoonlijke vaardigheden & $0,038^{* *}$ & $0,035^{* *}$ \\
\hline Fysieke behendigheid & $-0,011$ & $-0,010$ \\
\hline Kennis van de organisatie & $-0,028^{* *}$ & $-0,027^{* *}$ \\
\hline Probleemoplossend vermogen & 0,001 & 0,005 \\
\hline Plannen en organiseren & $-0,012$ & $-0,015$ \\
\hline Taalvaardigheden & $-0,019^{*}$ & $-0,017$ \\
\hline Rekenvaardigheden & $0,032^{* * *}$ & $0,031^{* * *}$ \\
\hline Computervaardigheden & $-0,008$ & $-0,011$ \\
\hline \multicolumn{3}{|l|}{ Leeftijdscategorie (ref. 16-34 jaar) } \\
\hline $35-44$ jaar & $0,181^{* * *}$ & $0,183^{* * *}$ \\
\hline $45-54$ jaar & $0,230^{* * *}$ & $0,233^{* * *}$ \\
\hline $55-66$ jaar & $0,290^{* * *}$ & $0,294^{* * *}$ \\
\hline \multicolumn{3}{|l|}{ Opleidingsniveau (ref. laag) } \\
\hline Middelbaar & 0,118 & 0,114 \\
\hline Hoog & $0,236^{* *}$ & $0,235^{* *}$ \\
\hline Verandering van beroep & 0,000 & 0,000 \\
\hline Verandering in belang van taken & Nee & Ja \\
\hline Constant & $2,576^{* * *}$ & $2,560^{* * *}$ \\
\hline $\mathrm{N}^{*} \mathrm{t}$ & 2.642 & 2.642 \\
\hline N & 987 & 987 \\
\hline R2 (overall) & 0,2162 & 0,2334 \\
\hline
\end{tabular}

${ }^{*} \mathrm{p}<0,10 ;{ }^{* *} \mathrm{p}<0,05 ;{ }^{* * *} \mathrm{p}<0,01$

Bron: NSS 2012 en 2017

\subsection{Complexiteit en kunde}

\section{Definities van complexiteit en kunde}

Voor in totaal 33 taken is aan werkenden gevraagd hoe belangrijk deze taken zijn in hun huidige werk. Respondenten konden daarbij antwoorden op een vijfpunts Likertschaal lopend van 'helemaal niet belangrijk / niet van toepassing' (1) tot 'cruciaal' (5). Deze schaal is opnieuw gecodeerd om te lopen tussen o en 4, waarbij o aangeeft dat iemand een bepaalde taak niet heeft. De antwoorden op deze vragen zijn gebruikt om op individueel niveau een indicator te ontwikkelen die de complexiteit van iemands werk aangeeft. Deze analyse is in 2013 op precies dezelfde wijze uitgevoerd (Fouarge \& de 
Grip, 2013). In deze paragraaf wordt de analyse overgenomen en aangevuld met de data uit 2017.

De complexiteit van het werk wordt gemeten door de antwoorden op het belang van de 33 taken bij elkaar op te tellen en te delen door de maximale haalbare score $\left(33^{*} 4\right)$. De indicator voor complexiteit wordt dan vermenigvuldigd met 100, zodat de score tussen o (voor werkenden die geen van de genoemde taken uitvoeren) en 100 ligt (voor werkenden voor wie alle 33 taken cruciaal zijn).

Complexiteit van het werk:

$$
C_{i}=\left(\frac{\sum_{j=1}^{33} T_{i j}}{33 * 4}\right) * 100
$$

Deze indicator is verwant aan de door Gorlich en Snower (2010) gebruikte indicator voor multitasking. Zij tellen daarbij echter alleen het aantal uitgevoerde taken, terwijl deze indicator ook rekening houdt met het belang van de taken op het werk. De complexiteit van het werk neemt dan toe met het aantal uit te voeren taken op het werk ('multitasking'), maar ook met de mate waarin de uitgevoerde taken belangrijk zijn voor het uitoefenen van de functie.

In de NSS is ook voor elke taak aan werkenden gevraagd hoe effectief zij zijn in het uitvoeren van de desbetreffende taak. Die effectiviteit is per taak $j$ op een schaal van 'bijna nooit'(1) tot 'bijna altijd' (5) gemeten. Ook deze schaal is opnieuw gecodeerd om van o tot 4 te lopen. De waarde van de indicator voor totale effectiviteit van werkende i wordt verkregen door de sommatie van ej voor alle taken die enige relevantie hebben voor het werk (de taken die voor iemands werk 'redelijk belangrijk', 'erg belangrijk' of 'cruciaal' zijn). We definiëren deze maat als kunde.

De maat voor kunde (K) per belangrijke taak wordt als volgt berekend:

$$
K_{i}=\frac{\sum_{j=1}^{33}\left(\left(T_{i j} \geq 2\right) * e_{i j}\right)}{\sum_{j=1}^{33}\left(T_{i j} \geq 2\right)}
$$

De schaal voor kunde loopt van o voor werkenden die nooit effectief zijn in het uitvoeren van enigszins belangrijke taken, tot 4 voor werkenden die altijd effectief zijn in het uitvoeren van enigszins belangrijke taken. 


\section{Complexiteit en kunde naar opleidingsniveau en leeftijd}

De complexiteit van het werk neemt toe met opleidingsniveau (Tabel 3.14). Dit impliceert dat hoogopgeleiden op hun werk meer taken uitvoeren dan lager opgeleiden en dat deze taken ook vaker belangrijk zijn. Bovendien is de effectiviteit waarmee hoger opgeleiden hun taken uitvoeren hoger dan de effectiviteit waarmee lager opgeleiden hun taken op het werk verrichten.

TABEL 3.14

Complexiteit en effectiviteit

\begin{tabular}{|c|c|c|c|c|}
\hline & \multicolumn{2}{|c|}{ Complexiteit } & \multicolumn{2}{|c|}{ Kunde } \\
\hline & gemiddeld & $Z()$ & gemiddeld & $Z()$ \\
\hline Alle werkenden & 48,10 & 0,00 & 2,96 & 0,00 \\
\hline \multicolumn{5}{|l|}{ Naar opleidingsniveau } \\
\hline Basisonderwijs, vmbo & 40,42 & $-0,48$ & 2,83 & $-0,19$ \\
\hline Mbo, havo, vwo & 47,19 & $-0,06$ & 2,95 & $-0,01$ \\
\hline Hbo, wo & 52,33 & 0,27 & 3,02 & 0,09 \\
\hline
\end{tabular}

Bron: NSS 2012 en 2017

Figuur 3.6 laat zien in hoeverre de complexiteit van het werk verschilt tussen jongere en oudere werkenden. Daarbij is een opmerkelijk verschil te zien in de ontwikkeling van de complexiteit over de arbeidsloopbaan tussen aan de ene kant laag- en middelbaar opgeleide werkenden en aan de andere kant hoogopgeleide werkenden. Voor zowel laag- als middelbaar opgeleiden neemt de complexiteit van het werk tot ongeveer 30 jaar gemiddeld toe om vervolgens gestaag af te nemen. Voor hoger opgeleiden neemt de complexiteit van het werk veel langer toe tot een leeftijd van ongeveer 50 jaar en daalt pas daarna. Het is belangrijk om in beschouwing te nemen dat de taken die werkenden van verschillende opleidingsniveaus uitvoeren, niet dezelfde (hoeven te) zijn. Het lijkt er dus op dat het belang van bepaalde taken en het aantal taken dat hoger opgeleiden uitvoeren langer toenemen dan dat van lager opgeleiden. 
FIGUUR 3.6

Complexiteit van het werk naar opleidingsniveau en leeftijd

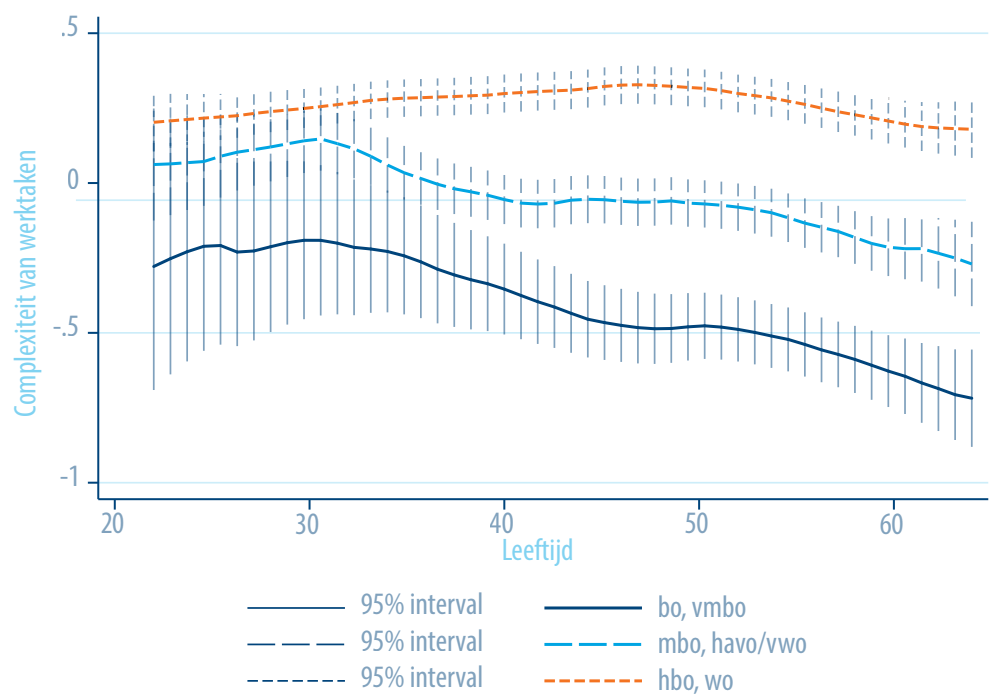

Bron: NSS 2012 en 2017

Figuur 3.7 laat voor verschillende opleidingsniveaus zien hoe de kunde in het uitvoeren van belangrijke taken zich ontwikkelt met het oplopen van de leeftijd. Voor laagopgeleiden geldt dat de kunde in het uitvoeren van belangrijke taken gemiddeld genomen toeneemt tot ongeveer 40 jaar, min of meer stabiel is tussen 40 en 50 jaar en daarna afneemt. De kunde in het uitvoeren van taken is redelijk stabiel voor middelbaar opgeleiden tot de leeftijd van 50 jaar, maar daalt daarna. Bij de hoger opgeleiden is de kunde in het uitvoeren van belangrijke taken min of meer stabiel over de leeftijd. Bij hoogopgeleide ouderen is de kunde op het werk significant hoger dan bij de lager opgeleiden. 
FIGUUR 3.7

Kunde in het uitvoeren van belangrijke taken

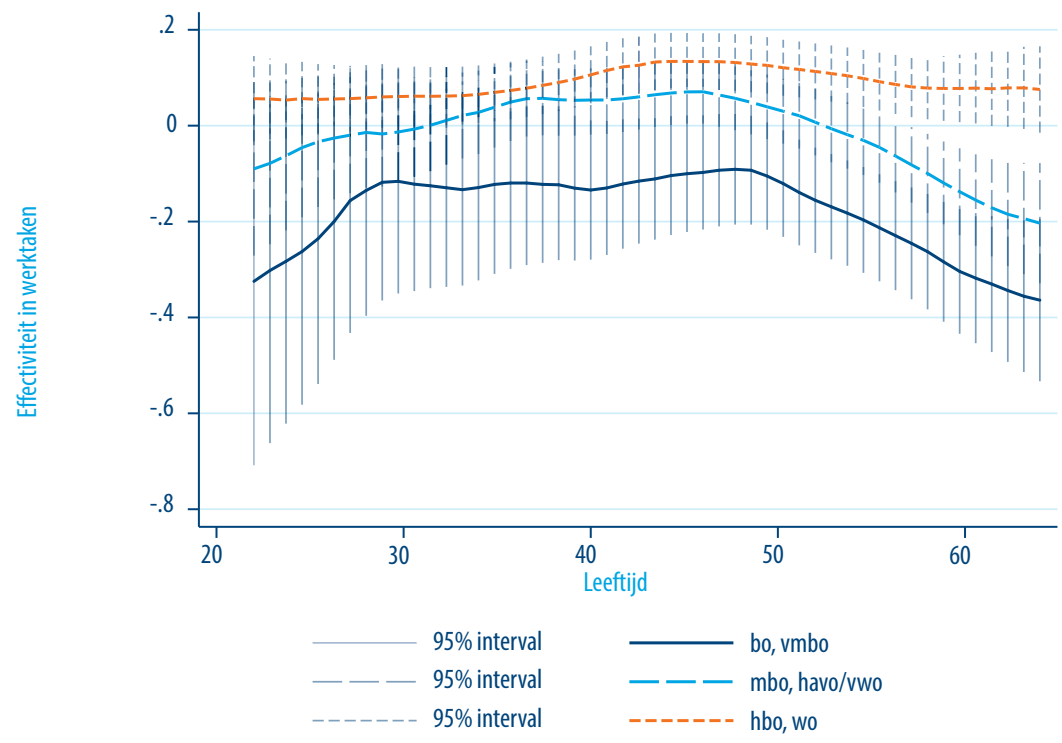

Bron: NSS 2012 en 2017

Tabel 3.15 geeft een overzicht van de schattingsresultaten van multivariate regressieanalyses voor complexiteit en kunde, zowel voor alle werkenden als voor hoogopgeleiden afzonderlijk. De analyses die betrekking hebben op alle werkenden, laten zien dat complexiteit en kunde een concaaf leeftijdspatroon hebben. De complexiteit van het werk is significant hoger als het opleidingsniveau hoger is. De hoger opgeleiden zijn bovendien meer kundig in het uitvoeren van hun taken. Vrouwen zijn significant minder vaak werkzaam in complexe banen. Er is echter geen significant verschil tussen mannen en vrouwen in de effectiviteit waarmee zij de voor hun beroep belangrijke taken uitvoeren. Deeltijders hebben een minder complex takenpakket en zijn minder effectief in het uitvoeren van hun taken dan voltijders. Deze verbanden doen zich ook voor bij de hoogopgeleide deeltijdwerkers. 
TABEL 3.15

Regressieanalyses voor complexiteit en kunde (gestandaardiseerde waardes)

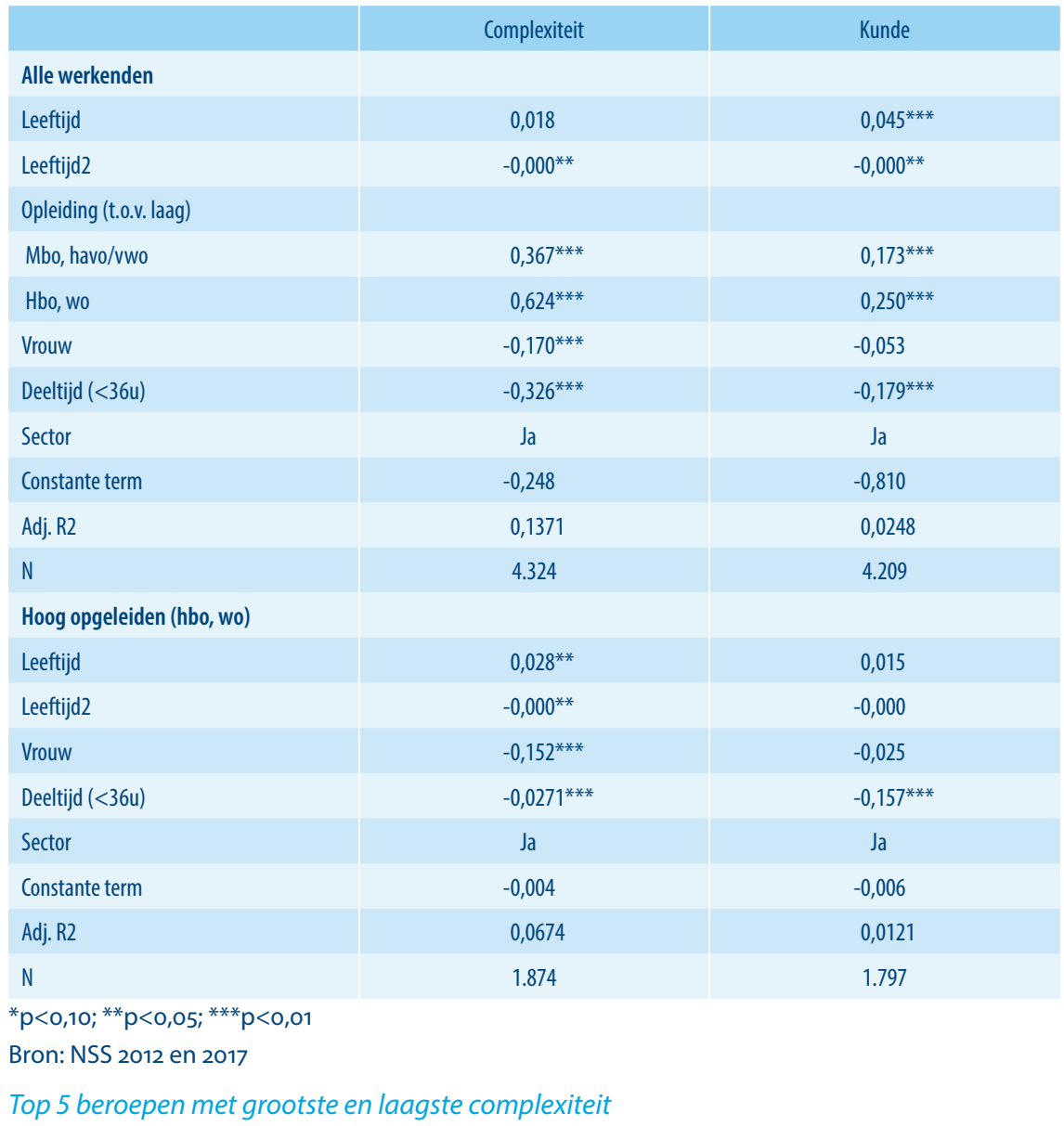

De gemiddelde complexiteit van het werk van alle werkenden in de gepoolde dataset van de NSS is 48,10 (zie Tabel 3.14). De complexiteit verschilt echter tussen beroepen, waarbij gekeken is naar beroepen met minimaal tien werkenden die hebben deelgenomen aan de NSS (Tabel 3.16). Uit de NSS blijkt dat managers productie de meest complexe baan hebben, met een gemiddelde score van 63,38 op een schaal van nul tot 100. Managers verkoop en marketing, accountants, managers ICT en zorginstellingen wijken daar niet veel van af, met allen een gemiddelde complexiteit van boven de 60 . Voor deze beroepen zijn relatief veel verschillende vaardigheden van belang. Relatief weinig vaardigheden zijn van belang voor vuilnisophalers en dagbladenbezorgers, schoonmakers en hulpkrachten in de bouw en industrie. Deze beroepen hebben een gemiddelde complexiteitsscore van rond de 30. 
TABEL 3.16

Top 5 beroepen met meeste en minste complexiteit

\begin{tabular}{|c|c|c|c|}
\hline \multicolumn{2}{|c|}{ Top 5 beroepen met meeste complexiteit } & \multicolumn{2}{|c|}{ Top 5 beroepen met minste complexiteit } \\
\hline Score & Beroep & Score & Beroep \\
\hline 63,38 & Managers productie & 25,23 & $\begin{array}{l}\text { Vuilnisophalers en } \\
\text { dagbladbezorgers }\end{array}$ \\
\hline 62,75 & $\begin{array}{l}\text { Managers verkoop en } \\
\text { marketing }\end{array}$ & 27,96 & Schoonmakers \\
\hline 62,31 & Accountants & 31,39 & $\begin{array}{l}\text { Hulpkrachten bouw en } \\
\text { industrie }\end{array}$ \\
\hline 61,11 & Managers ICT & 32,27 & Lassers en plaatbewerkers \\
\hline 60,81 & Managers zorginstellingen & 33,12 & Reisbegeleiders \\
\hline
\end{tabular}

Bron: NSS 2012 en 2017 



\section{MISMATCH}

\subsection{Skills gap en mismatch}

Werkenden zijn volgens eigen zeggen gemiddeld effectiever in het uitvoeren van taken dan het belang dat ze aan diezelfde taken hechten in hun huidige baan (zie Tabel 4.1). Dit kan een indicatie zijn dat ze meer kunnen dan wat er van hen op het werk gevraagd wordt. Er kan dan sprake zijn van overkwalificatie. Dat is gemiddeld het meest het geval bij taken waarvoor rekenvaardigheden benodigd zijn en gemiddeld het minst bij taken die probleemoplossend vermogen vereisen. Dit algemene beeld verschilt niet tussen 2012 en 2017.

\section{TABEL 4.1}

De effectiviteit waarmee taken worden uitgevoerd is gemiddeld hoger dan het belang van de werktaken

\begin{tabular}{|c|c|c|c|c|c|c|}
\hline \multirow[t]{2}{*}{ Geclusterde taken } & \multicolumn{3}{|c|}{2012} & \multicolumn{3}{|c|}{2017} \\
\hline & Belang1) & Effectiviteit ${ }^{2)}$ & $\Delta^{3)}$ & Belang1) & Effectiviteit ${ }^{2)}$ & $\Delta^{3)}$ \\
\hline Interpersoonlijke vaardigheden & 3,16 & 3,72 & $* *$ & 3,14 & 3,67 & ** \\
\hline Fysieke behendigheid & 2,71 & 3,53 & $* *$ & 2,63 & 3,49 & ** \\
\hline Kennis van de organisatie & 2,98 & 3,56 & & 2,88 & 3,36 & ** \\
\hline Probleemoplossend vermogen & 3,52 & 3,94 & $* *$ & 3,48 & 3,92 & ** \\
\hline Plannen en organiseren & 3,09 & 3,87 & $* *$ & 3,06 & 3,82 & ** \\
\hline \multicolumn{7}{|l|}{ Taalvaardig- } \\
\hline Heden & 2,75 & 3,75 & $* *$ & 2,78 & 3,71 & ** \\
\hline Rekenvaardigheden & 2,18 & 3,27 & $* *$ & 2,21 & 3,35 & ** \\
\hline Computer-vaardigheden & 2,70 & 3,32 & $* *$ & 2,68 & 3,36 & ** \\
\hline
\end{tabular}

1) betreft het gemiddelde van een vijfpunt-Likertschaal, waarbij $1=$ helemaal niet belangrijk/niet van toepassing; $2=$ niet erg belangrijk; $3=$ =redelijk belangrijk; $4=$ =erg belangrijk; $5=$ cruciaal 2) betreft het gemiddelde van een vijfpunt-Likertschaal, waarbij $1=$ bijna nooit; $5=$ altijd 3) betreft het significantieniveau van het verschil tussen 2017 en 2012, waarbij n.s.= niet significant verschillend van nul; ${ }^{*}=5 \%$-significant; ${ }^{* *}=1 \%$-significant

Bron: NSS 2012 en 2017 
Naast het vergelijken van het gemiddelde belang en de gemiddelde effectiviteit (skills gap) is het ook mogelijk om een indicator voor mismatch te ontwikkelen. Een geschikte manier daarvoor is om zowel voor het belang als voor de effectiviteit een grenswaarde te hanteren die bepaalt of er sprake is van een relatief hoog belang/effectiviteit of een relatief laag belang/effectiviteit. Door de vier hoog- en laag-combinaties van belang en effectiviteit vervolgens met elkaar te kruisen, ontstaan er twee combinaties die symbool staan voor een mismatch en twee combinaties die symbool staan voor een match. Schematisch ziet dat er als volgt uit (Figuur 4.1), waarbij gekozen is voor een grenswaarde van het gemiddelde van de gehele populatie ${ }^{11}$ bij zowel belang als effectiviteit. Als het belang of de effectiviteit hoger is dan het gemiddelde van de populatie, betekent dit dat de taken relatief belangrijk zijn voor het werk of relatief effectief worden uitgevoerd. Linksboven is sprake van overkwalificatie, rechtsonder van onderkwalificatie.

\section{FIGUUR 4.1}

Schematische weergave van de mismatch tussen het belang en de effectiviteit van werktaken

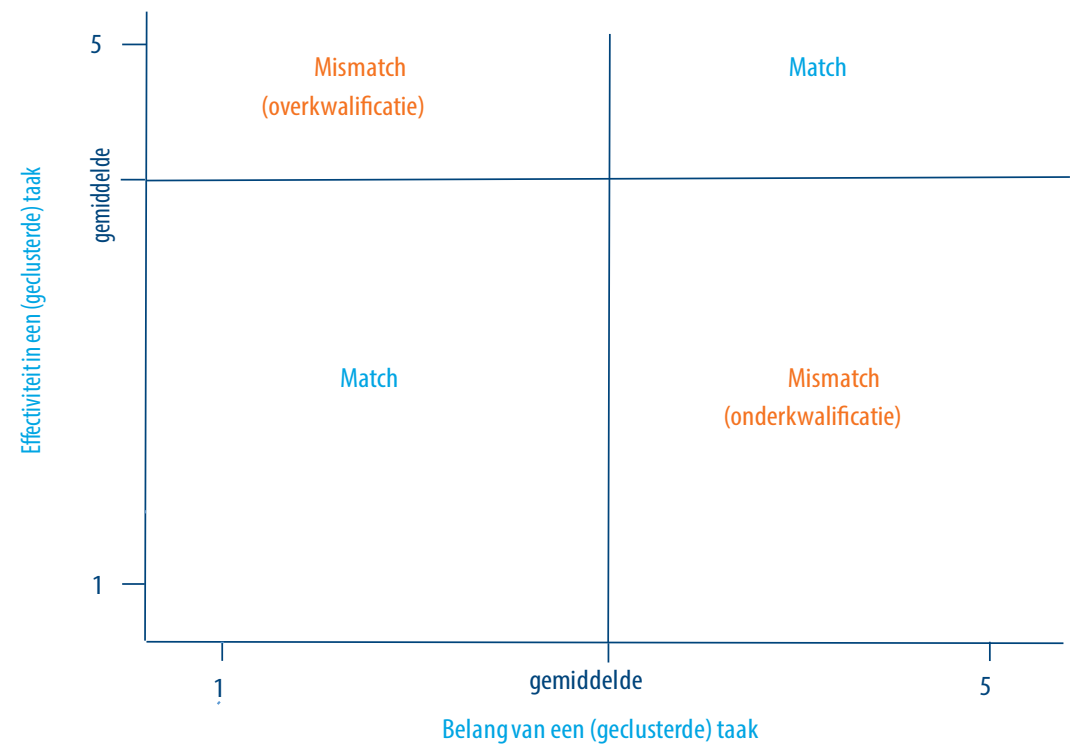

Bij toepassing van het gemiddelde van de populatie als grenswaarde en indicator van mismatch (Tabel 4.2), blijkt dat er per taak 30 tot 40 procent van de werkenden onder- of overgekwalificeerd is. Onderkwalificatie (hoog belang, lage effectiviteit) is relatief het grootst bij kennis van de organisatie, namelijk 20 procent. Overkwalificatie (laag belang, hoge effectiviteit) is relatief het hoogst bij plannen en organiseren, namelijk 30 procent.

11 Het gemiddelde van de populatie is per NSS-jaar afzonderlijk vastgesteld. Deze gemiddelden zijn weergegeven in Tabel 4.1. 
TABEL 4.2

Mismatch naar geclusterde taken (procenten)

\begin{tabular}{|l|c|c|c|c|}
\hline & Match & & Mismatch & \\
\hline & $\begin{array}{c}\text { laag belang - } \\
\text { lage effectiviteit }\end{array}$ & $\begin{array}{c}\text { hoog belang - } \\
\text { hoge effectiviteit }\end{array}$ & $\begin{array}{c}\text { hoog belang - } \\
\text { lage effectiviteit }\end{array}$ & $\begin{array}{c}\text { laag belang- } \\
\text { hoge effectiviteit }\end{array}$ \\
\hline Interpersoonlijke vaardigheden & $29 \%$ & $37 \%$ & $15 \%$ & $19 \%$ \\
\hline Fysieke behendigheid & $29 \%$ & $35 \%$ & $15 \%$ & $21 \%$ \\
\hline Kennis van de organisatie & $27 \%$ & $38 \%$ & $20 \%$ & $15 \%$ \\
\hline Probleemoplossend vermogen & $23 \%$ & $42 \%$ & $14 \%$ & $21 \%$ \\
\hline Plannen en organiseren & $28 \%$ & $32 \%$ & $10 \%$ & $30 \%$ \\
\hline Taalvaardigheden & $26 \%$ & $39 \%$ & $15 \%$ & $20 \%$ \\
\hline Rekenvaardigheden & $35 \%$ & $34 \%$ & $10 \%$ & $21 \%$ \\
\hline Computervaardigheden & $33 \%$ & $35 \%$ & $11 \%$ & $21 \%$ \\
\hline
\end{tabular}

Bron: NSS 2012 en 2017

\section{Top 5 beroepen met meeste mismatch}

Tabel 4.3 geeft een overzicht van de vijf beroepen waarbij de match tussen het belang en de effectiviteit het grootst is, onderscheiden naar over- en onderkwalificatie per cluster van taken. Hiervoor zijn beide jaren van de NSS gepoold en alleen beroepen ${ }^{12}$ meegenomen die door minimaal 10 respondenten worden uitgeoefend. De mate van overkwalificatie verschilt per beroep en per taak en is in de meeste gevallen maximaal 40 à 50 procent. Bij de top 5 beroepen met de meeste overkwalificatie valt één specifiek beroep op, namelijk de auteurs en taalkundigen die op bijna alle taken voor een relatief groot deel overgekwalificeerd zijn. Ook de uitvoerend kunstenaars komen bij meerdere taken voor in de top 5 .

De maximale onderkwalificatie per taak ligt met gemiddeld 30 procent een stuk lager dan de maximale overkwalificatie. Ook de spreiding binnen de top 5 is kleiner. Dit bevestigt dat onderkwalificatie minder wordt geaccepteerd door werkgevers dan overkwalificatie. Tegelijkertijd toont de top 5 met de meeste onderkwalificatie aan dat er geen typische beroepen zijn waarbij sprake is van onderkwalificatie. Verschillende typen managers en journalisten komen bij slechts enkele taken in de top 5 .

12 Dit betreft beroepen geclassificeerd volgens de beroepenindeling ROA CBS 2014. 
TABEL 4.3

Top 5 beroepen met meeste over- en onderkwalificatie

\begin{tabular}{|c|c|c|c|}
\hline \multicolumn{2}{|c|}{ Top 5 beroepen met meeste overkwalificatie } & \multicolumn{2}{|c|}{ Top 5 beroepen met meeste onderkwalificatie } \\
\hline$\%$ & Beroep & $\%$ & Beroep \\
\hline \multicolumn{4}{|c|}{ Interpersoonlijke vaardigheden } \\
\hline $47 \%$ & Bouwarbeiders afbouw & $33 \%$ & Managers logistiek \\
\hline $45 \%$ & Auteurs en taalkundigen & $30 \%$ & Financieel specialisten en economen \\
\hline $42 \%$ & Meubelmakers, kleermakers en stoffeerders & $29 \%$ & Maatschappelijk werkers \\
\hline $38 \%$ & Fotografen en interieurontwerpers & $29 \%$ & Docenten hoger onderwijs en hoogleraren \\
\hline $37 \%$ & Metaalbewerkers en constructiewerkers & $29 \%$ & Specialisten personeels- en loopbaanontwikkeling \\
\hline \multicolumn{4}{|c|}{ Fysieke behendigheid } \\
\hline $40 \%$ & Verleners van overige persoonlijke diensten & $36 \%$ & Veetelers \\
\hline $36 \%$ & Architecten & $33 \%$ & Bouwarbeiders ruwbouw \\
\hline $36 \%$ & Auteurs en taalkundigen & $33 \%$ & Vuilnisophalers en dagbladenbezorgers \\
\hline $36 \%$ & Journalisten & $32 \%$ & Hulpkrachten bouw en industrie \\
\hline $35 \%$ & Accountants & $30 \%$ & Schoonmakers \\
\hline \multicolumn{4}{|c|}{ Kennis van de organisatie } \\
\hline $45 \%$ & Auteurs en taalkundigen & $43 \%$ & Lassers en plaatbewerkers \\
\hline $42 \%$ & Architecten & $40 \%$ & Politie-inspecteurs \\
\hline $36 \%$ & Journalisten & $39 \%$ & Politie en brandweer \\
\hline $35 \%$ & Beveiligingspersoneel & $35 \%$ & Elektriciens en elektronicamonteurs \\
\hline $35 \%$ & Fysiotherapeuten & $31 \%$ & Specialisten personeels- en loopbaanontwikkeling \\
\hline \multicolumn{4}{|c|}{ Probleemoplossend vermogen } \\
\hline $55 \%$ & Auteurs en taalkundigen & $29 \%$ & Laboranten \\
\hline $43 \%$ & Docenten hoger onderwijs en hoogleraren & $29 \%$ & Politie en brandweer \\
\hline $43 \%$ & Uitvoerend kunstenaars & $29 \%$ & Journalisten \\
\hline $40 \%$ & Verleners van overige persoonlijke diensten & $25 \%$ & Architecten \\
\hline $40 \%$ & Overheidsbestuurders & $23 \%$ & Software- en applicatieontwikkelaars \\
\hline \multicolumn{4}{|c|}{ Plannen en organiseren } \\
\hline $57 \%$ & Lassers en plaatwerkers & $25 \%$ & Managers ICT \\
\hline $54 \%$ & Fotografen en interieurontwerpers & $24 \%$ & Productiemachinebedieners \\
\hline $50 \%$ & Politie-inspecteurs & $22 \%$ & Biologen en natuurwetenschappers \\
\hline $50 \%$ & Reisbegeleiders & $22 \%$ & Managers onderwijs \\
\hline $50 \%$ & Keukenhulpen & $21 \%$ & Journalisten \\
\hline \multicolumn{4}{|c|}{ Taalvaardigheden } \\
\hline $64 \%$ & Auteurs en taalkundigen & $33 \%$ & Managers gespecialiseerde dienstverlening \\
\hline $50 \%$ & Reisbegeleiders & $29 \%$ & Verzorgenden \\
\hline $46 \%$ & Fotografen en interieurontwerpers & $29 \%$ & Veetelers \\
\hline $43 \%$ & Uitvoerend kunstenaars & $26 \%$ & Gebruikersondersteuning ICT \\
\hline
\end{tabular}




\begin{tabular}{|l|l|l|l|}
\hline $43 \%$ & Lassers en plaatwerkers & $25 \%$ & Managers ICT \\
\hline \begin{tabular}{l|l|l}
\hline Rekenvaardigheden \\
$50 \%$
\end{tabular} & Uitvoerend kunstenaars & & \\
\hline $43 \%$ & Journalisten & $33 \%$ & Managers horeca \\
\hline $43 \%$ & Politie en brandweer & $29 \%$ & Chauffeurs auto's, taxi's en bestelwagens \\
\hline $42 \%$ & Gebruikersondersteuning ICT & $24 \%$ & Procesoperators \\
\hline $42 \%$ & Machinemonteurs & $21 \%$ & Uitvoerend kunstenaars \\
\hline Computervaardigheden & $20 \%$ & Managers zorginstellingen \\
\hline $45 \%$ & Auteurs en taalkundigen & & \\
\hline $44 \%$ & Psychologen en sociologen & $28 \%$ & Procesoperators \\
\hline $42 \%$ & Meubelmakers, kleermakers en stoffeerders & $25 \%$ & Machinemonteurs \\
\hline $36 \%$ & Kassamedewerkers & $21 \%$ & Journalisten \\
\hline $36 \%$ & Uitvoerend kunstenaars & $21 \%$ & Grafisch vormgevers en productieontwerpers \\
\hline Bron: NSS & & \\
\hline
\end{tabular}

Bron: NSS 2012 en 2017

\subsection{Samenhang tussen persoonskenmerken en mismatch}

Interessant om te onderzoeken is of de mismatch bij taken samenhangt met persoonskenmerken van werkenden. Daarvoor maken we gebruik van twee modelspecificaties. In de eerste specificatie is de mismatch opgenomen als het absolute verschil tussen de effectiviteit en het belang voor een specifieke taak, de skills gap zoals gepresenteerd aan het begin van dit hoofdstuk. Het belang en de effectiviteit van ieder individu is gecorrigeerd voor het gemiddelde belang en effectiviteit van de totale populatie in de NSS. De skills gap per werkende per taak $\left(\mathrm{E}_{\mathrm{i}, \mathrm{t}}-\mathrm{B}_{\mathrm{i}, \mathrm{t}}\right)$ schatten we via een OLS-regressie, waarbij we als verklarende factoren de persoonskenmerken geslacht, leeftijd en opleidingsniveau $\left(\mathrm{X}_{\mathrm{i}, \mathrm{t}}\right)$ opnemen. We controleren voor beroepssegmenten en maken gebruik van geclusterde standaardfouten voor de werkenden die in beide jaren van de NSS voorkomen. De vergelijking ziet er als volgt uit, waarbij we a en $\beta$ schatten en $\mu$ de storingsterm is:

$$
E_{i, t}-B_{i, t}=\alpha+\beta X_{i, t}+\mu
$$

Als tweede specificatie gebruiken we de indicator voor mismatch zoals gespecificeerd in paragraaf 4.1, waarbij een werkende per taak in één van de volgende vier categorieën valt:

1. Match: taak heeft een laag belang en de werkende heeft daarin een lage effectiviteit;

2. Match: taak heeft een hoog belang en de werkende heeft daarin een hoge effectiviteit;

3. Mismatch in de vorm van onderkwalificatie: taak heeft een hoog belang en de werkende heeft daarin een lage effectiviteit; 
4. Mismatch in de vorm van overkwalificatie: taak heeft een laag belang en de werkende heeft daarin een hoge effectiviteit.

Deze indicator voor mismatch onderzoeken we door middel van het schatten van een logitmodel. De verklarende factoren zijn identiek aan die van de OLS-regressie hierboven en het model ziet er als volgt uit:

$$
M_{i, t}=\alpha+\beta X_{i, t}+\mu
$$

Mi,t staat voor de kans dat een werkende i een mismatch heeft ten aanzien van een specifieke taak $t$, waarbij een 1 correspondeert met een mismatch en een o met een match. Dit logitmodel schatten we eerst enkelvoudig voor overkwalificatie ten opzichte van match en enkelvoudig voor onderkwalificatie ten opzichte van match. Vervolgens schatten we alle vier de categorieën van (mis)match simultaan in een multinomiaal logitmodel, waarbij categorie 2 (hoog belang en hoge effectiviteit) als referentie wordt genomen.

De uitkomsten van de OLS- en enkelvoudige logitregressies laten een divers verband zien tussen persoonskenmerken en mismatch dat afhangt van de werktaken (Tabellen 4.4 en 4.5). Op basis daarvan zijn dus geen algemene conclusies te trekken over verbanden tussen de persoonskenmerken en onder- of overkwalificatie van werkenden. Een hoger opleidingsniveau heeft bijvoorbeeld zowel positieve als negatieve verbanden met de over- en onderkwalificatie voor bepaalde taken. Dat geldt ook voor de leeftijd van werkenden en het geslacht. Mogelijk wordt dit verklaard doordat over- of onderkwalificatie tijdelijk van aard is en daardoor niet systematisch samenhangt met de hier onderzochte persoonskenmerken van werkenden. Opvallend is overigens dat het OLSen logit-model voor vijf van de acht taken tot dezelfde uitkomsten komen ten aanzien van overkwalificatie. Voor onderkwalificatie is dat bij geen van alle taken het geval.

Ook de multinomiale logitregressies bevestigen dat er geen eenduidig verband is tussen de persoonskenmerken van werkenden en hun (mis)match ten aanzien van taken. Vrouwen zijn volgens dit model bijvoorbeeld eerder overgekwalificeerd dan mannen op het gebied van kennis van de organisatie, maar zijn hier tegelijkertijd ook vaker ondergekwalificeerd voor. Dergelijke uitkomsten zijn gevonden voor meerdere taken en ook voor de andere persoonskenmerken die zijn onderzocht. 


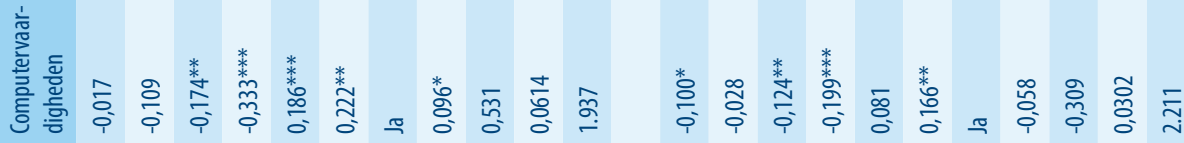

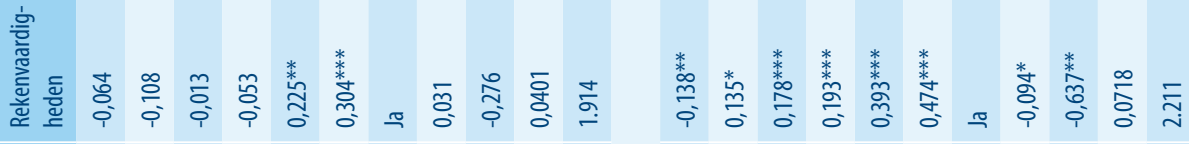

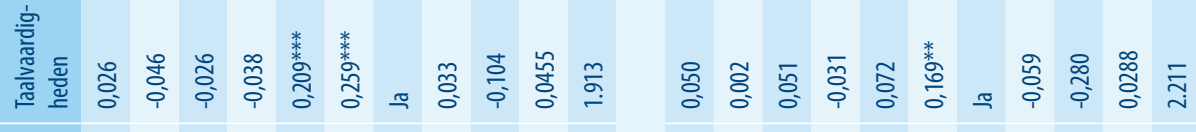

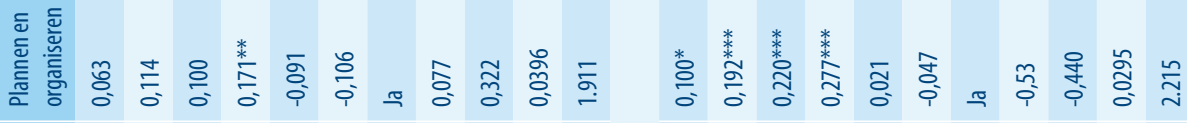
总

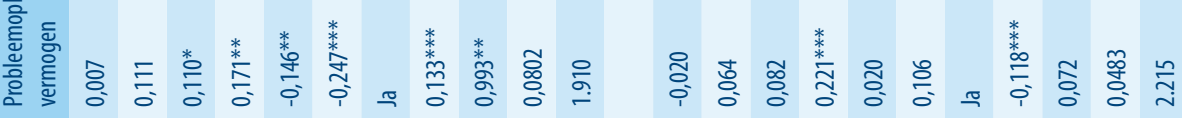

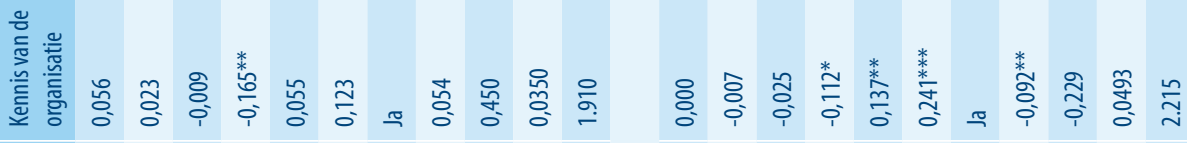

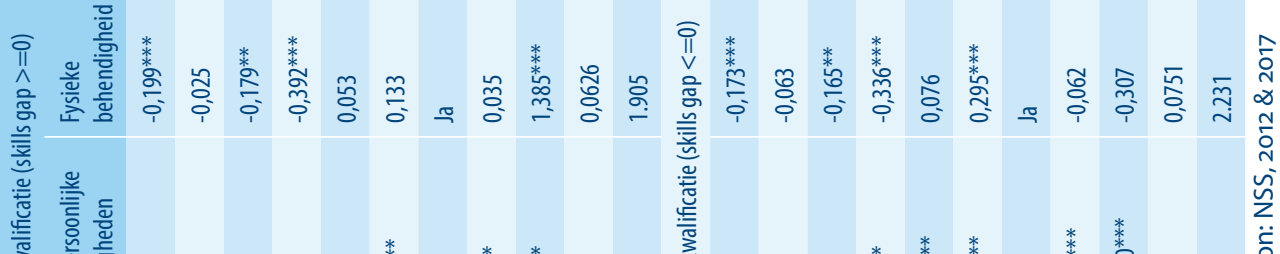

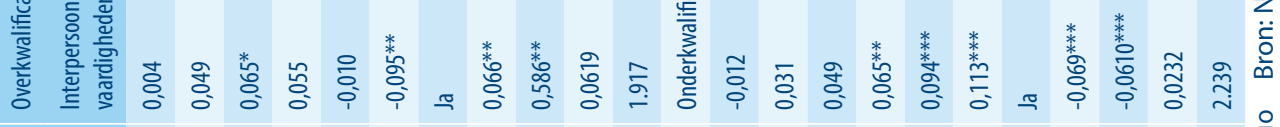

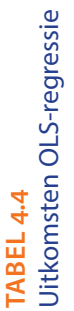

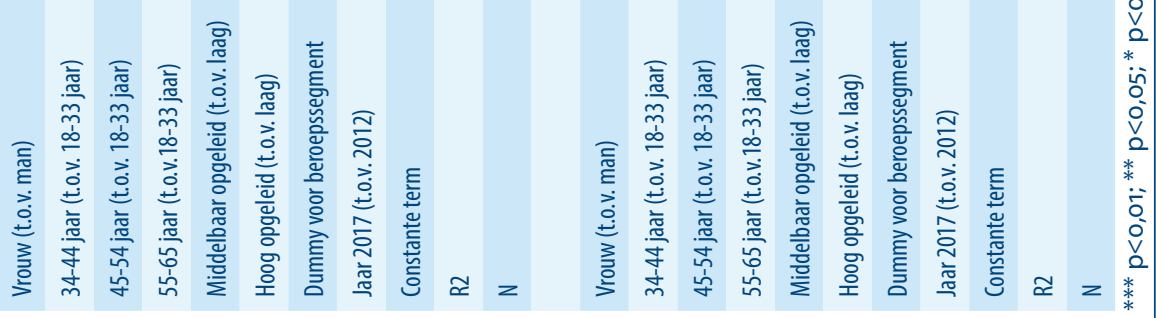




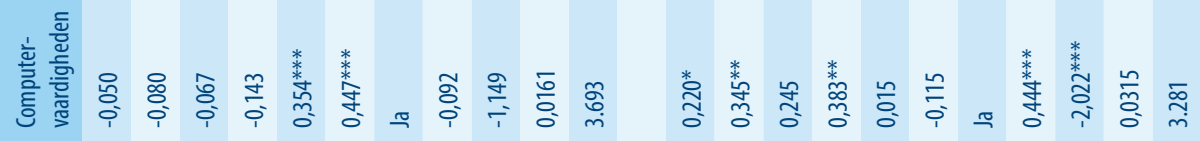

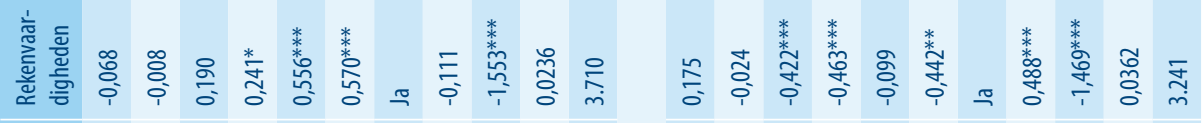

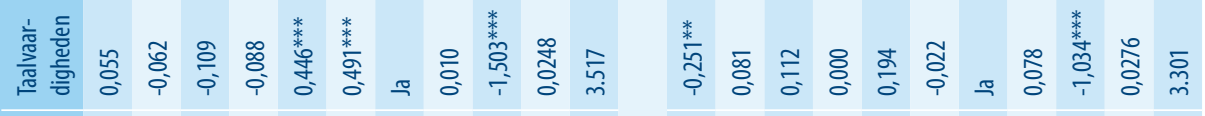

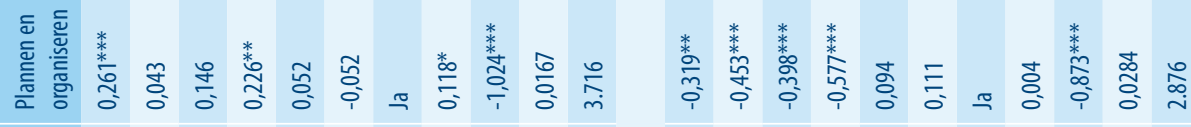
旁

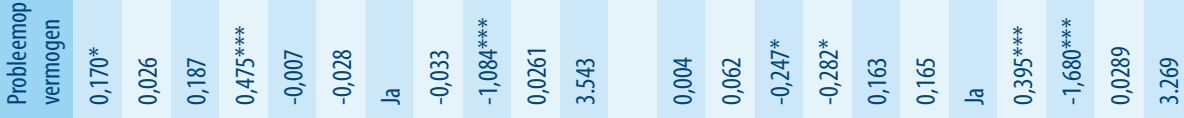

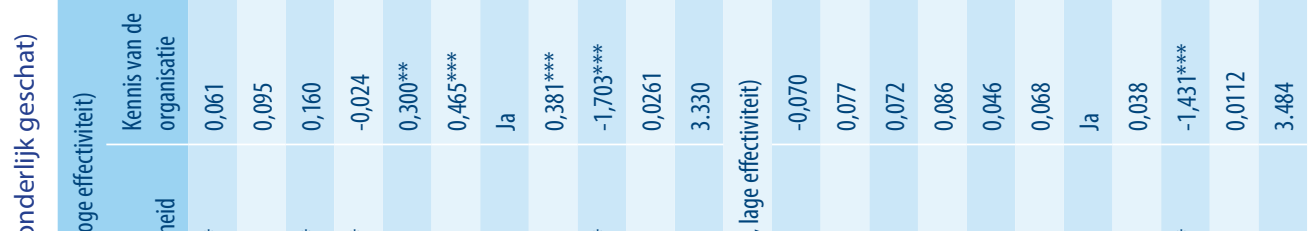

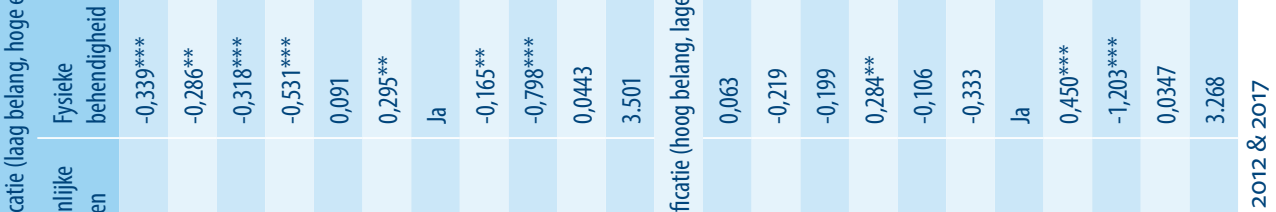

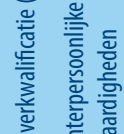




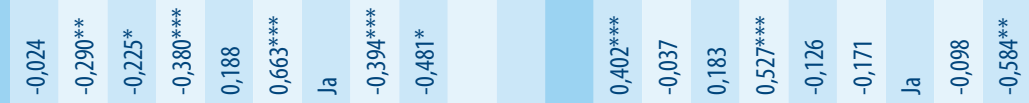

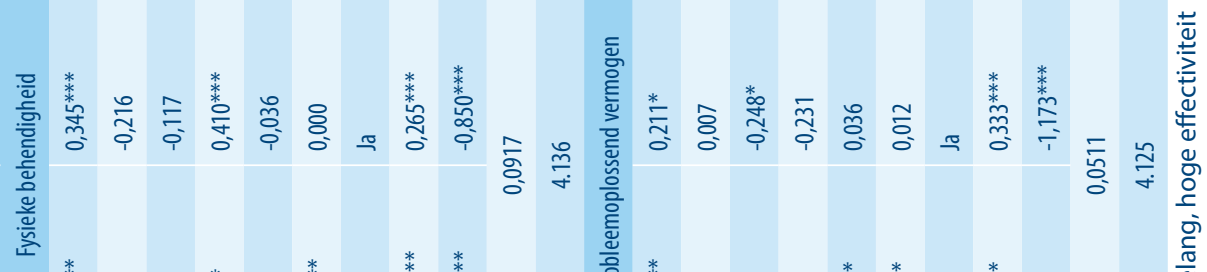

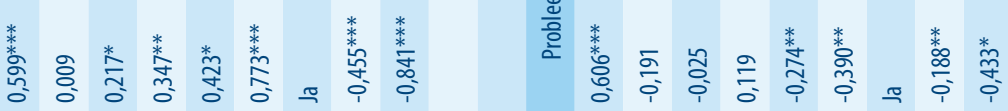

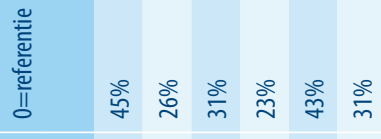

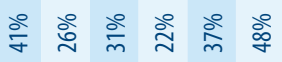

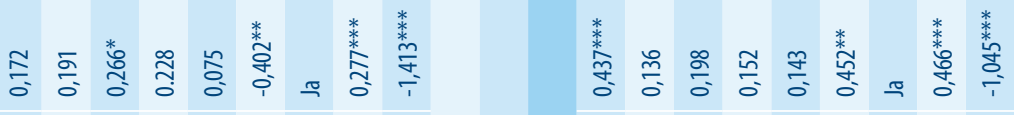

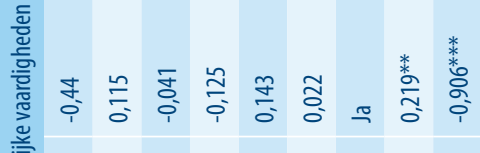

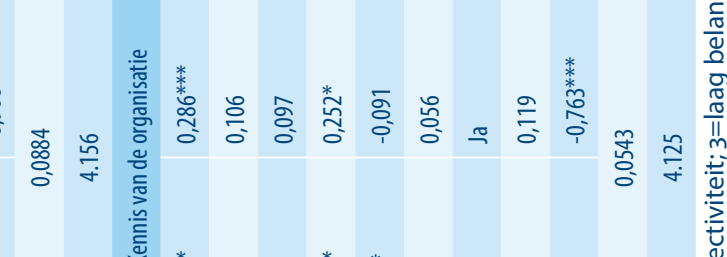

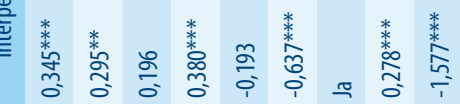

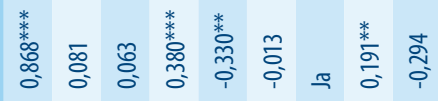

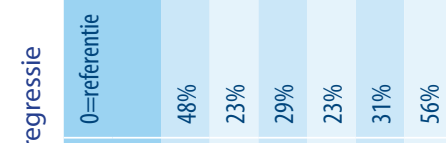

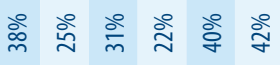
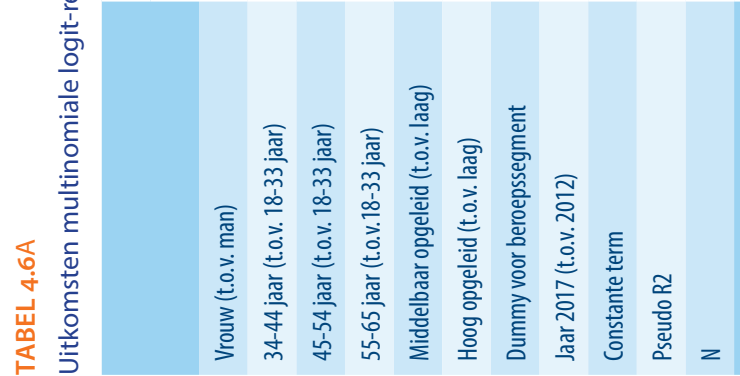

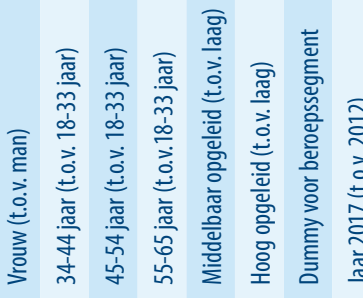

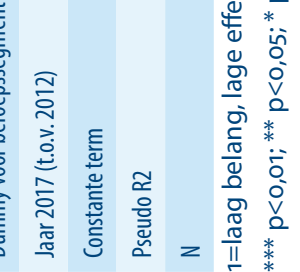




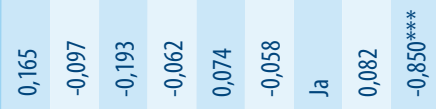

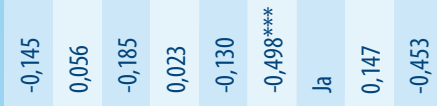

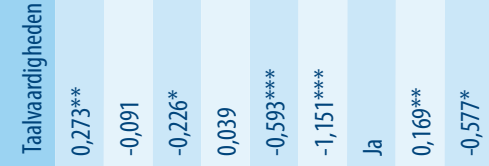

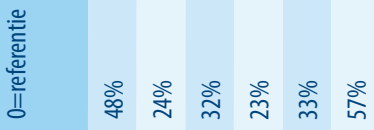

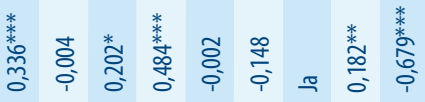

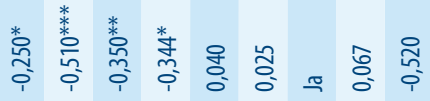

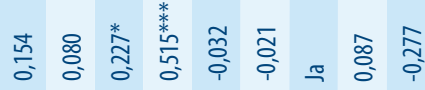

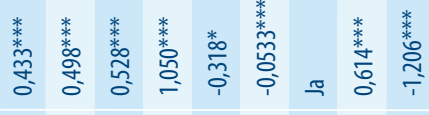

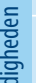

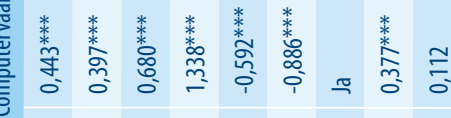

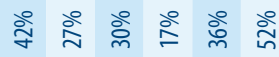

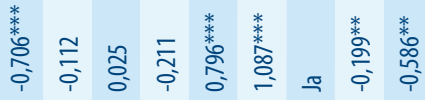

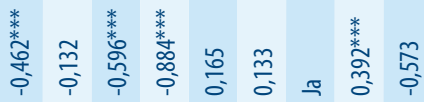

휸

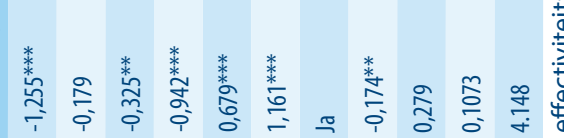

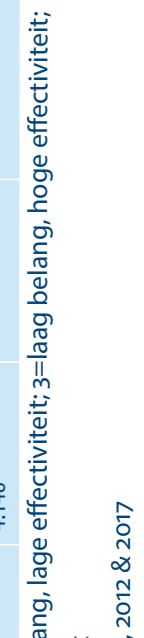

$\frac{0}{\tilde{n}}$

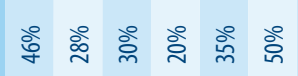

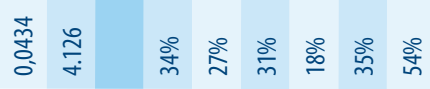

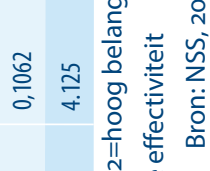

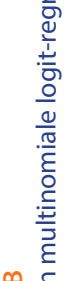

邹

广் 岗竞

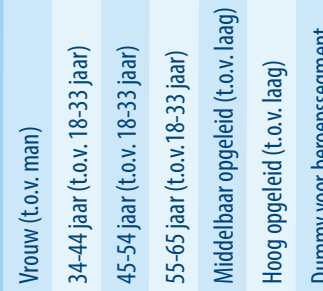

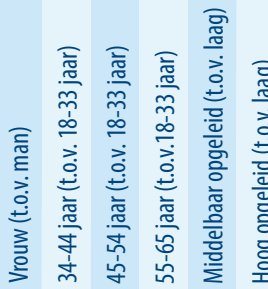

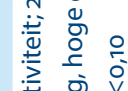
艺 के 离 $\frac{\pi}{2}$ * 잉 :

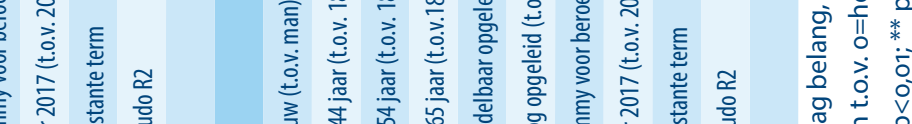

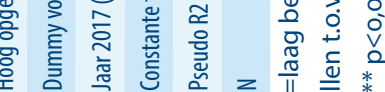




\subsection{Relatie mismatch en loon}

Een mismatch tussen het gevraagde niveau van competenties en de feitelijke taakeffectiviteit kan mogelijk voor een verlies aan productiviteit zorgen; dit geldt zowel bij overkwalificatie als bij onderkwalificatie. Productiviteit laat zich lastig meten met survey data, maar we kunnen wel iets zeggen over het bruto uurloon van de werkenden wat in principe de beloning voor de productieve inzet op het werk is. Voordat we ingaan op de relatie tussen de match van belang en effectiviteit en het loon beschrijven we eerst de samenhang tussen het loon en het belang van taken.

\section{Loon en belang van taken}

Figuur 4.2 laat de correlatie zien tussen het loon van werkenden in beroepen en het belang van taken in deze beroepen.13 Het laat zien dat naarmate taken van groter belang zijn op het werk, de beloning voor werkenden hoger is. Fysieke behendigheid is hierbij de enige uitzondering; voor deze taken ligt de beloning juist lager als het belang van de taken op het werk groter is. De correlatie tussen het belang van taken op het werk en het bruto uurloon is in alle gevallen significant. Ook wanneer gecontroleerd wordt voor de verschillen in samenstelling tussen beroepen naar geslacht, leeftijd, opleiding en jaren in dienst blijven de correlaties in Figuur 4.2 significant, behalve voor fysieke taken en kennis van de organisatie.

\section{Mismatch en loon}

Om de relatie tussen de mismatch in taken en het bruto uurloon in kaart te brengen regresseren we het bruto uurloon van werkenden (in log) op de indicator voor de mismatch en kenmerken van de respondenten (geslacht, leeftijd, opleiding, en aantal jaren werkzaam bij de werkgever). De indicatoren voor de mismatch zijn als volgt samengesteld:

- Match: hoog belang - hoge effectiviteit (als referentie categorie)

- Match: laag belang - lage effectiviteit

- Mismatch: hoog belang - lage effectiviteit

- Mismatch: laag belang - hoge effectiviteit

13 Hierbij is gebruik gemaakt van beroepsgroepen. Het loon heeft betrekking op het bruto persoonlijk inkomen per uur en is afgeleid van het bruto maandinkomen en het aantal contractuele werkuren, beiden afkomstig uit het LISS panel. Voor werknemers gaat het hier hoofdzakelijk om loon uit betaalde arbeid. 
FIGUUR 4.2

Bruto uurloon en belang van taken naar beroep
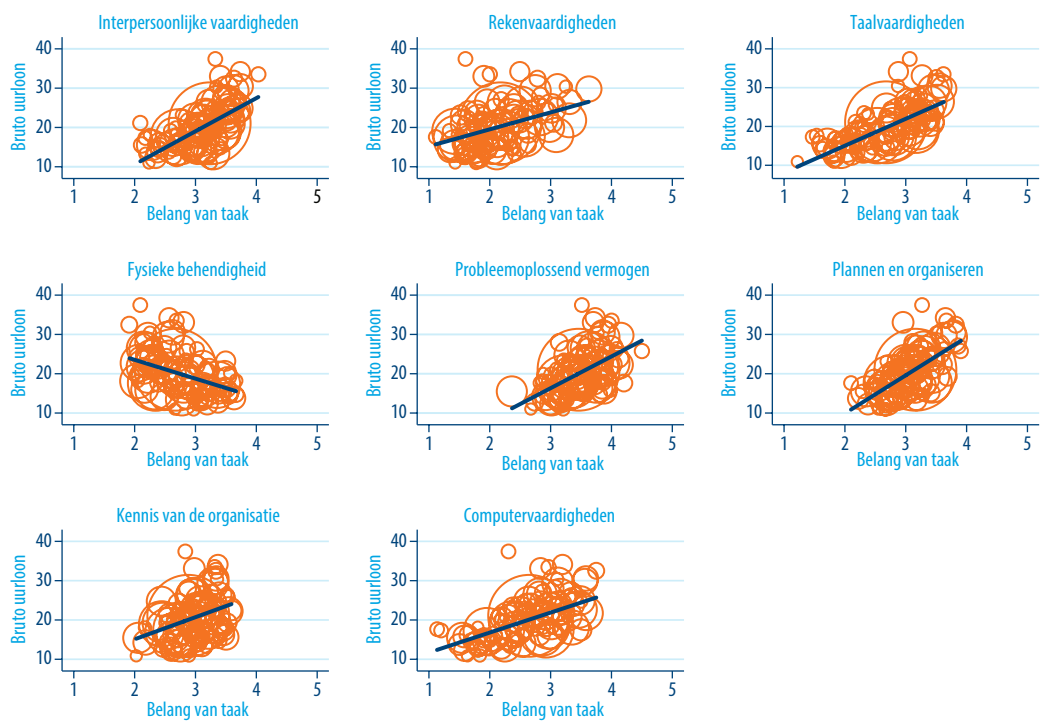

Tabel 4.6 laat de resultaten van deze analyses zien, zonder en met controle voor het beroepssegment van de werkenden. Wanneer niet gecontroleerd wordt voor het beroep geldt voor alle taken dat werkenden voor wie het belang van een taak laag is en de effectiviteit in deze taak ook laag ligt een significant lager uurloon verdienen. Alleen voor fysieke behendigheid geldt, zoals verwacht kan worden, het omgekeerde. Wanneer gecontroleerd wordt voor het beroep blijkt nog steeds voor de meeste taken dat werkenden met een laag belang en een lage effectiviteit per uur minder verdienen dan werkenden waarvoor zowel belang en affectiviteit hoog zijn. Een voorbeeld hiervan is dat werkenden met een laag belang van interpersoonlijke vaardigheden en een lage effectiviteit daarin 5,6\% per uur minder verdienen nadat gecontroleerd is voor menselijk kapitaal variabelen en het sorteren in beroepen. Een lage effectiviteit in rekenvaardigheden, taalvaardigheden en plannen en organiseren terwijl het belang in het werk hoog is gaat gepaard met een significant lager uurloon. Een dergelijke mismatch op de andere taken resulteert niet in een significant lager uurloon. Een hoge effectiviteit in interpersoonlijke en taalvaardigheden terwijl het belang laag is gaat ook gepaard met een significant lager uurloon. Het tegenovergestelde geldt voor fysieke behendigheid. 


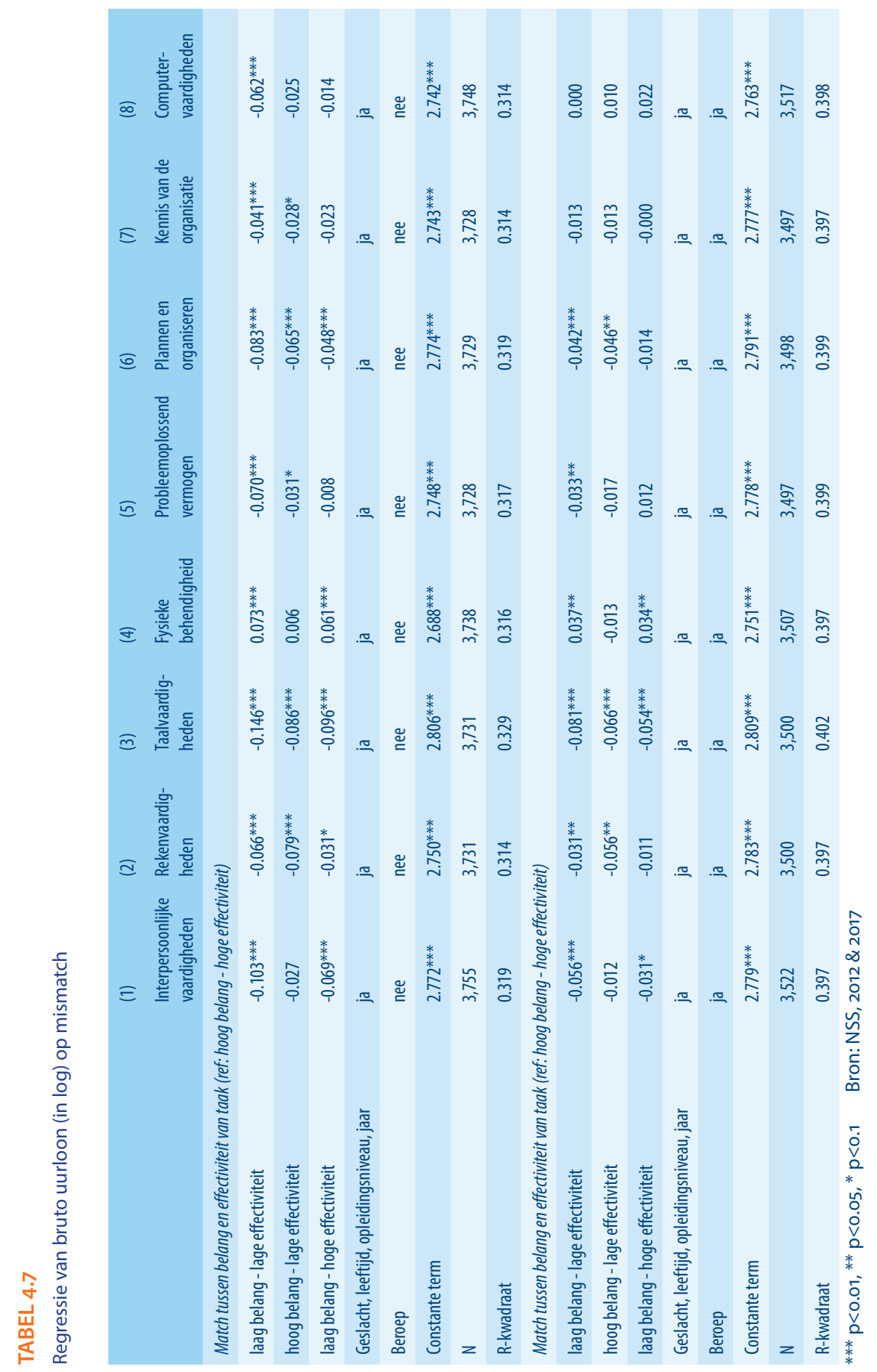




\subsection{Compenserende mechanismen bij mismatch van taken}

Taken worden niet altijd effectief uitgevoerd. Deze ineffectiviteit levert niet per definitie problemen op; een bakker maakt bijvoorbeeld weinig gebruik van computers waardoor ineffectiviteit in deze taak niet problematisch hoeft te zijn. Echter wordt het wel problematisch als de taken die niet effectief worden uitgevoerd belangrijk zijn op het werk, of in de toekomst belangrijker gaan worden. De werkende moet dan een taak uitvoeren maar is hier niet effectief in. Dit gaat ten koste van de productiviteit en kan de inzetbaarheid van de werkende in gevaar brengen. In Figuur 4.3 geven we deze situatie schematisch weer aan de hand van een belangrijke taak die niet effectief uitgevoerd wordt (zie Taak C zoals omschreven in Hoofdstuk 2).

FIGUUR 4.3

Schematische weergave (mis)matches tussen effectiviteit en belang van taken

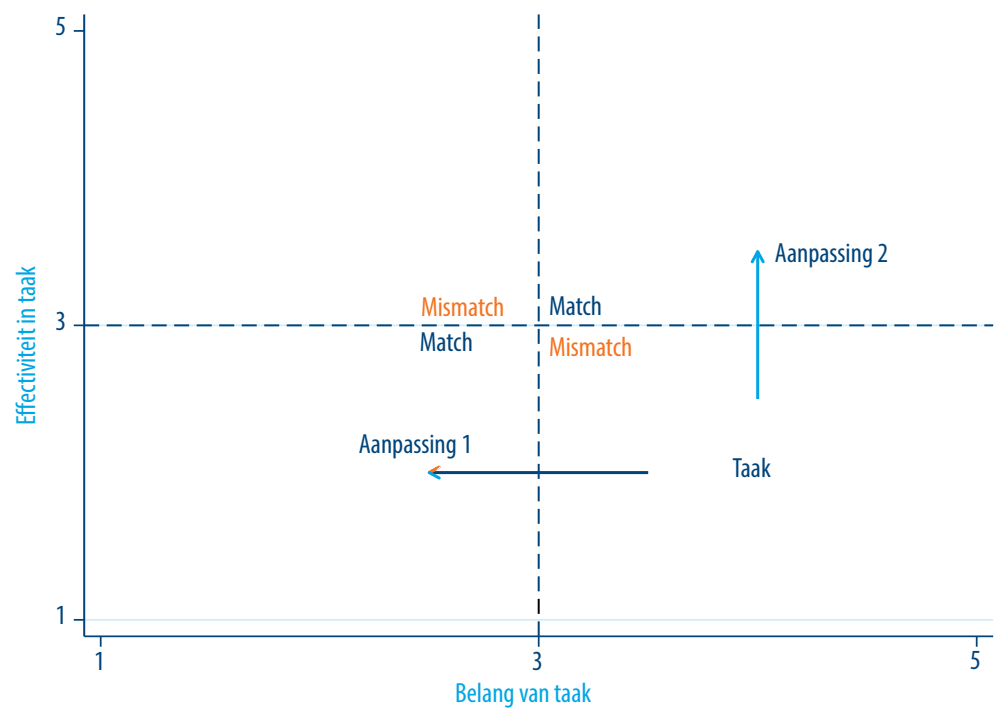

Zoals Figuur 4.3 laat zien zijn er twee aanpassingen voor werkenden om het verlies in productiviteit, doordat ze een belangrijke taak niet effectief uit kunnen voeren, te voorkomen. Allereerst is het mogelijk dat er verandering plaatsvindt in het belang van de taak. Als het belang van de taak afneemt zou de mismatch kunnen veranderen in een match, de taak schuift in Figuur 4.3 naar links (aanpassing 1) waardoor zowel het belang als de effectiviteit laag zullen zijn. Met deze beweging zou het probleem rondom deze taak zich vanzelf oplossen. Echter, deze aanpassing is lastig te beïnvloeden door de werkende zelf aangezien veranderingen in het belang van taken immers afhankelijk zijn van bijvoorbeeld veranderingen in de technologie. Een tweede mogelijke aanpassing is 
een verbetering van de effectiviteit in het uitvoeren van de taak (aanpassing 2). Als de werkende actie onderneemt om effectiever te worden in de taak, door bijvoorbeeld het volgen van een cursus, kan de werkende ervoor zorgen dat er toch een match ontstaat tussen belang en effectiviteit.

\section{Verandering in belang van taken (Aanpassing 1)}

Om in kaart te kunnen brengen of aanpassing 1 zal plaatsvinden in de nabije toekomst is er een indicatie over de toekomstige ontwikkeling van het belang van taken nodig. Neemt het belang van de taak af dan zal er in ieder geval een beweging in de richting van aanpassing 1 plaatsvinden. Wanneer de taak niet in belang gaat afnemen zal er door de werkende zelf actie ondernomen moeten worden om de mismatch op te lossen. Aan respondenten van de NSS is voor een willekeurige taak die belangrijk is, maar niet effectief uitgevoerd wordt gevraagd: "Wat zou in 2022 volgens u het belang zijn van deze taak in het soort werk dat u nu doet?" (op een schaal van $1=$ helemaal niet belangrijk tot $5=$ cruciaal). Hiermee kunnen we een indicatie krijgen of de belangrijke taak die niet effectief wordt uitgevoerd nog belangrijk zal zijn over vijf jaar. In Figuur 4.4 laten we de resultaten per taak zien. Bij de interpretatie van deze resultaten moet er echter rekening gehouden worden met de frequentie van de verschillende taken die als Taak C naar voren zijn gekomen. Zoals de Tabel A.1 in Bijlage A laat zien komen namelijk niet alle groepen taken even vaak voor.

\section{FIGUUR 4.4}

Wat is over vijf jaar het belang van taken die nu belangrijk zijn maar waar men niet effectief in is?

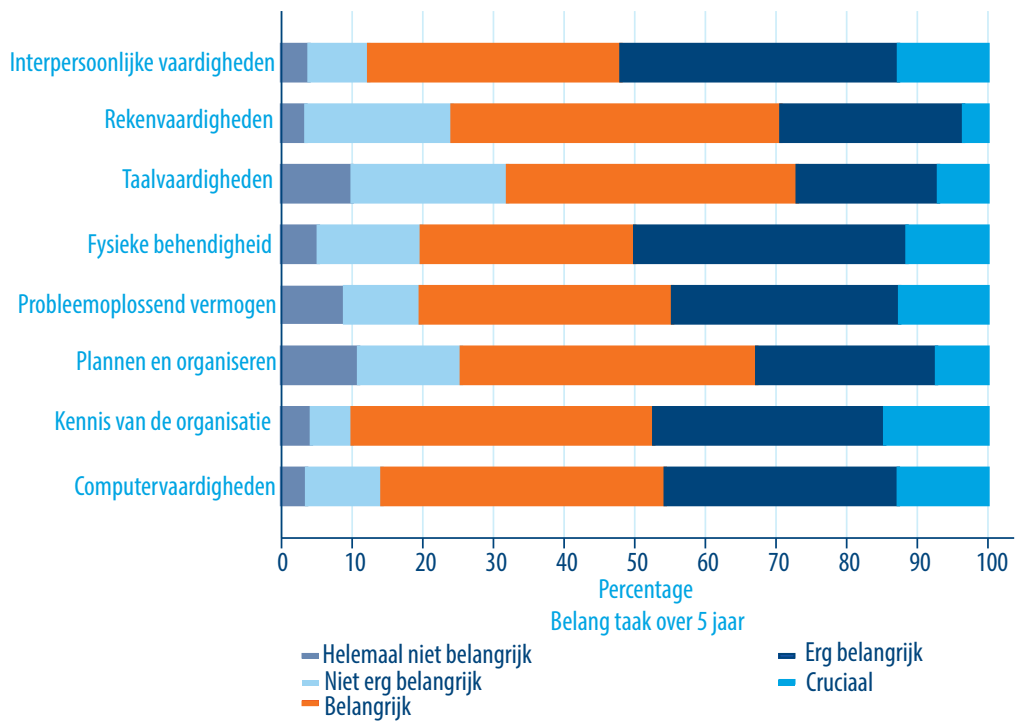


Uit de figuur komt naar voren dat voor een groot deel van de respondent de belangrijke taak die niet effectief uitgevoerd wordt over vijf jaar nog steeds belangrijk zal zijn. Vooral als deze taak binnen de groepen interpersoonlijke vaardigheden, kennis van de organisatie of gebruik van computers valt (taken die in de laatste 20 jaar steeds belangrijker zijn geworden; zie Fouarge, 2017) geeft maar een klein deel van de respondenten aan dat de taak helemaal niet of niet erg belangrijk zal zijn over vijf jaar. Binnen deze groepen zal men andere manieren moeten zoeken om de problemen rondom deze taak op te lossen. Er zijn echter ook drie taken waarvoor de kans aanwezig is dat deze taken in belang zullen afnemen in de komende vijf jaar. Ongeveer 30 procent van de respondenten geeft namelijk aan dat wanneer de taak binnen taalvaardigheden zal vallen het belang over vijf jaar niet hoog zal zijn. Voor deze groep taken lijken werkenden in te schatten dat tekortkomende vaardigheden minder problematisch zullen zijn omdat de taken minder belangrijk zullen worden, en het probleem van ineffectiviteit zich vanzelf oplost. Het valt echter te bezien of taalvaardigheden de komende vijf jaar minder belangrijk zullen worden. De analyses in hoofdstuk 3 laten in ieder geval niet zien dat taalvaardigheden in de afgelopen vijf jaar minder belangrijks zijn geworden.

\section{Effectiviteit vergroten (Aanpassing 2)}

Aangezien het niet vanzelfsprekend is dat taken waar men niet effectief in is aan belang zullen inboeten is het vergroten van de effectiviteit (aanpassing 2) een meer waarschijnlijke strategie om de inzetbaarheid op peil te houden. Om te achterhalen hoe men effectiever denkt te kunnen worden in deze taken maken we gebruik van de volgende vraag uit de NSS: "Welke van de onderstaande activiteiten kunnen ervoor zorgen dat u deze taak effectiever kan uitvoeren", waarna respondenten een lijst van activiteiten te zien kregen (bijvoorbeeld het volgen van cursussen, aanpassingen aan werkomgeving/tempo) die zij konden aankruisen (meer antwoorden mogelijk). Tabel 4.7 laat zien hoeveel procent van de respondenten voor de verschillende activiteiten gekozen heeft. 


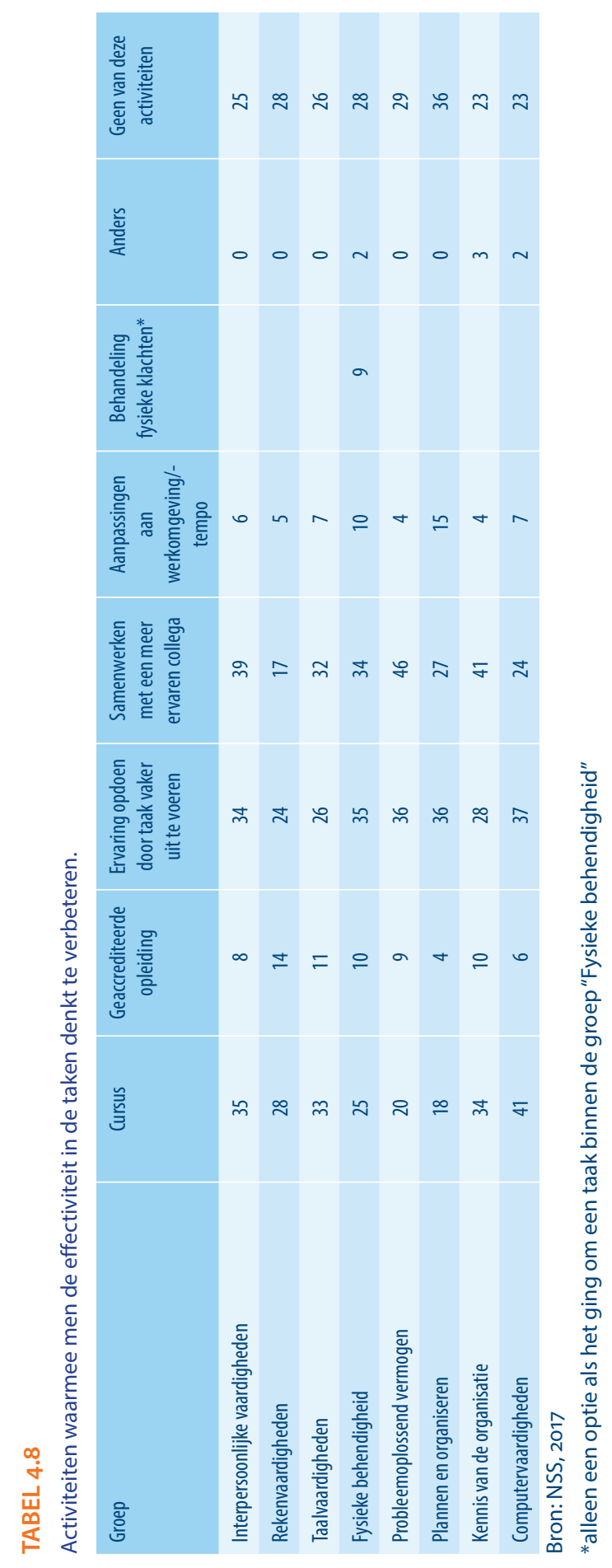


Over het algemeen worden het volgen van een cursus, ervaring opdoen door taak vaker uit te voeren en samenwerken met een meer ervaren collega het vaakst genoemd als manier om de effectiviteit van taken te verbeteren (Tabel 4.7). Merk op dat het hier gaat om het oordeel van de respondenten zelf. Het is hiermee niet gezegd dat dit de meest effectieve manieren zijn om de taakeffectiviteit te verhogen. Het volgen van een cursus blijkt voornamelijk voor computervaardigheden de beoogde manier te zijn om effectiever te worden in deze taken, 41 procent van de respondenten kiest voor deze mogelijkheid, al wordt leren door te doen door 37 procent ook genoemd. Voor alle taken geeft meer dan 20 procent van de respondenten aan dat zij de effectiviteit denken te verbeteren door middel van ervaring opdoen door de taak vaker uit te voeren. Samenwerken met een meer ervaren collega wordt vaak aangegeven als activiteit om de effectiviteit in probleemoplossend vermogen en kennis van de organisatie te verbeteren. Voor plannen en organiseren geeft een groot deel van de respondenten aan dat geen van de activiteiten ertoe zal bijdragen dat de effectiviteit in deze taak wordt verbeterd.

Vervolgens laten we in Tabel 4.8 zien in hoeverre er verschillen in de manier van het verbeteren van de effectiviteit naar opleidingsniveau waar te nemen zijn. Doordat taken niet voor elk opleidingsniveau hetzelfde ingevuld dienen te worden zijn er mogelijk ook verschillen in de manieren waarop ze hier effectiever in worden. Tabel 4.8 laat duidelijke verschillen zien tussen de opleidingsniveaus. Enkel voor probleemoplossend vermogen en kennis van de organisatie geven alle opleidingsniveau dezelfde activiteit het vaakst aan. Ter verbetering van interpersoonlijke vaardigheden geven laagopgeleiden het vaakst het volgen van een cursus aan terwijl middelbaar en hoogopgeleiden het vaakst samenwerken met een meer ervaren collega als de beste optie zien om zich te verbeteren in de taak. Voor rekenvaardigheden zien laagopgeleiden vaak dat er geen activiteit is aangegeven waarmee ze effectiever kunnen worden in de taak. Middelbaar opgeleiden denken dit juist vaak door middel van cursusdeelname te kunnen verbeteren. Onder hoogopgeleiden is er geen consensus waar te nemen als het gaat om het verbeteren van rekenvaardigheden aangezien ze net zo vaak cursus of vaker de taak uitvoeren kiezen als geen van de activiteiten. Taalvaardigheden denken laag- en hoogopgeleiden het vaakst te verbeteren door samen te werken met een meer ervaren collega terwijl middelbaar opgeleiden het volgen van een cursus als de beste optie zien. Fysieke behendigheid is volgens het merendeel van de laagopgeleiden een taak dat niet door een van de genoemde activiteiten verbeterd kan worden. Middelbaar opgeleiden denken dit het vaakst wel te kunnen door middel van cursusdeelname, hoogopgeleiden juist door samen te werken met een ervaren collega. Ook voor plannen en organiseren geeft het grootste deel van de laagopgeleiden aan deze taak niet te kunnen leren met de genoemde activiteiten. Ter verbetering van deze taak geven middelbaar opgeleiden samenwerken met een ervaren collega het vaakst aan als activiteit om de effectiviteit te vergroten. Hoogopgeleiden denken de taak het vaakst te verbeteren door de taak vaker uit te voeren. Voor computervaardigheden zit er minder verschil tussen de opleidingsniveaus. Voor alle niveaus komen cursusdeelname en het vaker uitoefenen van de taak het vaakst naar voren, hoewel het vaker uitvoeren van taken door hoogopgeleiden een minder grote rol speelt dan voor de andere opleidingsniveau. 


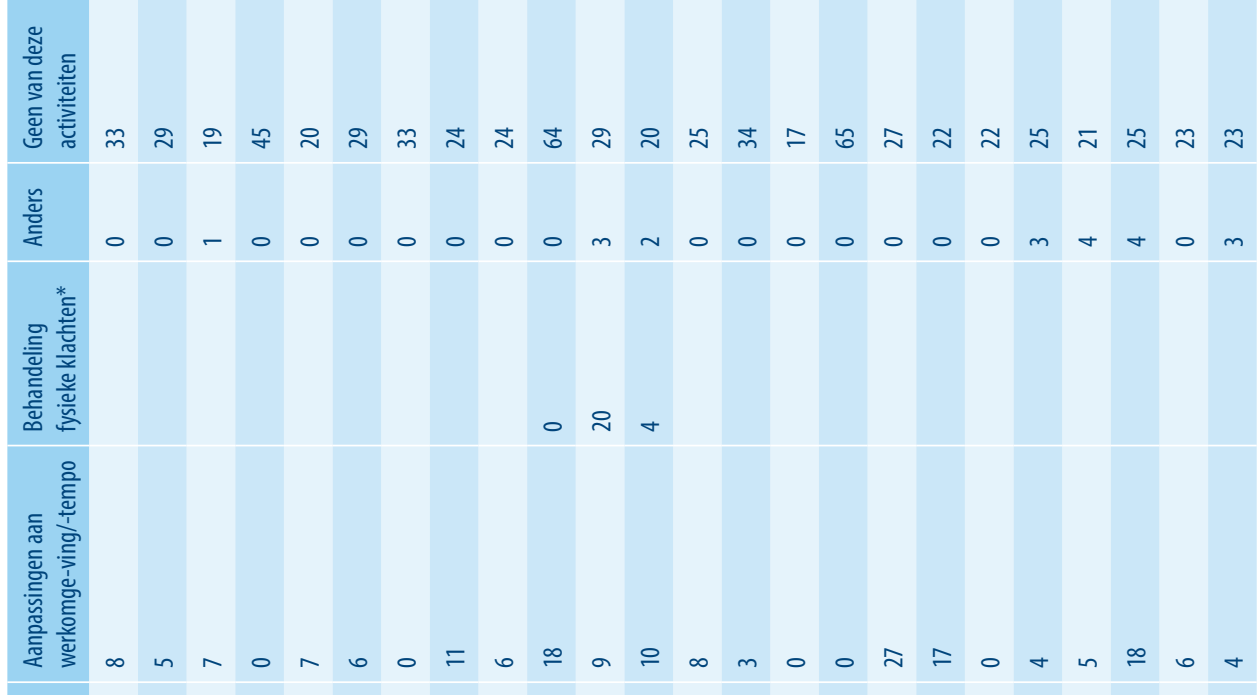

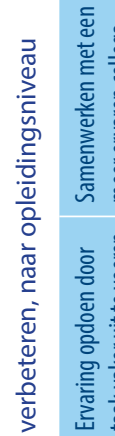

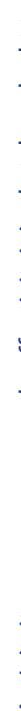
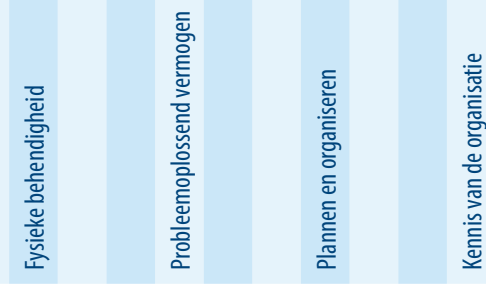

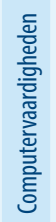

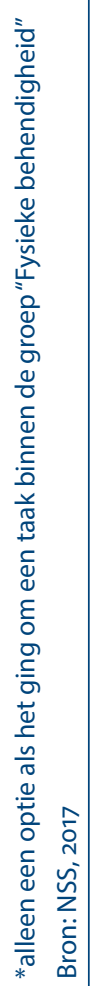





\section{LEVENSLANG LEREN, LOOPBAANSTAPPEN EN TAKEN}

\subsection{Waar leert men vaardigheden}

De vaardigheden die nodig zijn op het werk kunnen op verschillende manieren geleerd zijn. Vooral leren op school en op het werk zijn hier voor de hand liggende voorbeelden van manieren waarop men kan leren. Echter blijkt uit onderzoek dat men ook buiten school of het werk leert, bijvoorbeeld van vrijwilligerswerk, zelfstudie, mantelzorg of tijd met kinderen (Fouarge et al., 2018). Om in kaart te brengen waar men welke vaardigheden leert wordt er in deze paragraaf allereerst een onderscheid gemaakt tussen leren op school en leren op het werk. Vervolgens wordt er gekeken naar welke andere vormen van leren er gebruikt worden om de op het werk benodigde vaardigheden eigen te maken.

\section{Op school of op het werk}

Op basis van de NSS zijn we in staat om een indicatie te geven over de mate waarin vaardigheden eerder op school of op het werk worden geleerd of door een combinatie van beide. Respondenten zijn gevraagd om voor 35 taken op een schaal van 1 tot 5 aan te geven of zij de specifieke vaardigheden voor die taak meer op school of juist meer op het werk hebben geleerd. Tevens hadden de respondenten de optie om aan te geven dat ze de vaardigheid nooit hebben geleerd of dat deze niet van toepassing is in hun werk. ${ }^{14}$ Hiermee zijn er op basis van dit blok vier manieren te onderscheiden waarop de vaardigheid is geleerd: (voornamelijk) op school, zowel op school als op het werk, (voornamelijk) op het werk, of nooit geleerd. Figuur 5.1 laat de verdeling zien van deze vier manieren van leren per groep van vaardigheden.

14 De schaal was als volgt opgesteld: op school (1), meer op school dan op het werk (2), evenveel op school als op het werk (3), meer op het werk dan op school (4), op het werk (5), niet van toepassing/nooit geleerd (9). 


\section{FIGUUR 5.1}

Waar leren werkenden vaardigheden, in percentages ${ }^{15}$

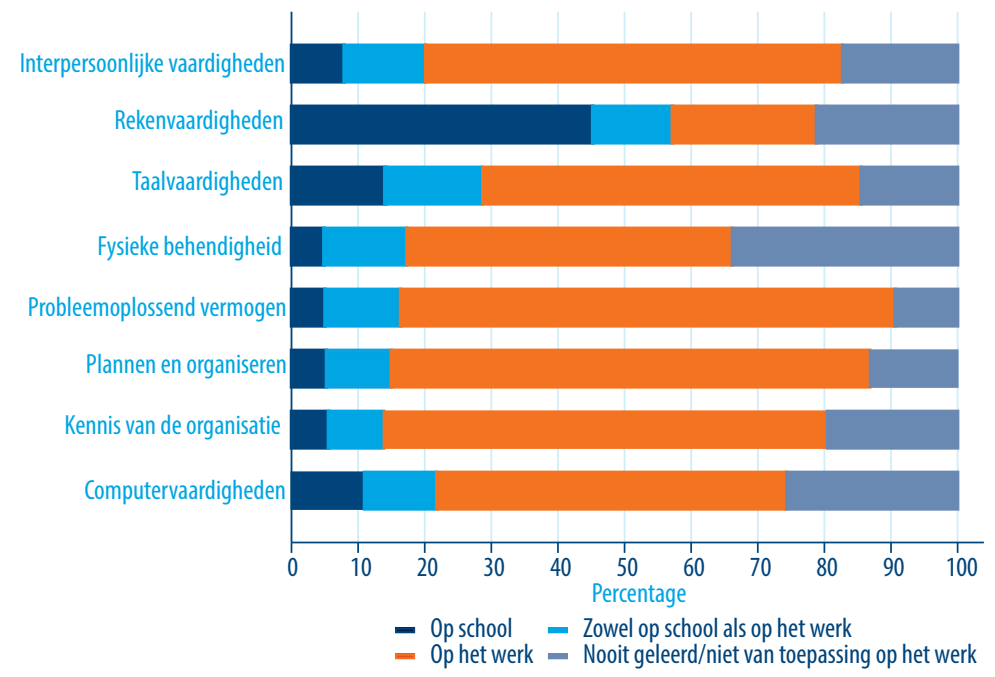

Bron: NSS, 2012 \& 2017

Uit Figuur 5.1 komt duidelijk naar voren dat het merendeel van de vaardigheden voornamelijk op het werk worden geleerd. Dit blijkt vooral voor probleemoplossend vermogen en plannen en organiseren het geval te zijn. Voor beide vaardigheden geeft meer dan 70 procent van de respondenten aan dat ze deze voornamelijk op het werk hebben geleerd. Rekenvaardigheden blijken daarentegen juist voornamelijk op school geleerd te worden; 45 procent van de respondent heeft dit aangegeven. Deze groep vaardigheden is daarmee wel een uitzondering omdat alle andere groepen vaardigheden vaker op het werk worden geleerd.

In Figuur 5.1 is het opmerkelijk om te zien dat er voor een aantal vaardigheden een aanzienlijk aandeel van de respondenten heeft aangegeven deze nooit geleerd te hebben. Vooral voor computervaardigheden ligt het niet voor de hand dat deze nooit geleerd zijn. Een mogelijke verklaring voor deze hoge aandelen kan echter liggen in het belang van de taken. Onafhankelijk van het takenpakket van de respondent hebben alle respondenten namelijk in de NSS voor alle taken moeten aangeven waar ze deze geleerd hebben. Dit zou dus ook kunnen gaan over taken die ze nooit hoeven uit te voeren. Zo hoeft bijvoorbeeld een bakker geen gebruik te maken van computers om zijn werk uit te voeren. Om hiervoor te corrigeren laten we in Figuur 5.2 de verdeling nog een

$\overline{15} 1263$ respondenten hebben zowel de NSS 2012 als de NSS 2017 ingevuld. 
keer zien met de additionele selectie dat de taken alleen meegenomen worden als ze ook relevant zijn voor het huidige werk van de respondenten: taken zijn alleen meegenomen als de respondenten enige vorm van belang hebben aangegeven. ${ }^{16}$

\section{FIGUUR 5.2}

Waar leren werkenden taken gegeven dat de taken ook relevant zijn voor het huidige werk, in percentages

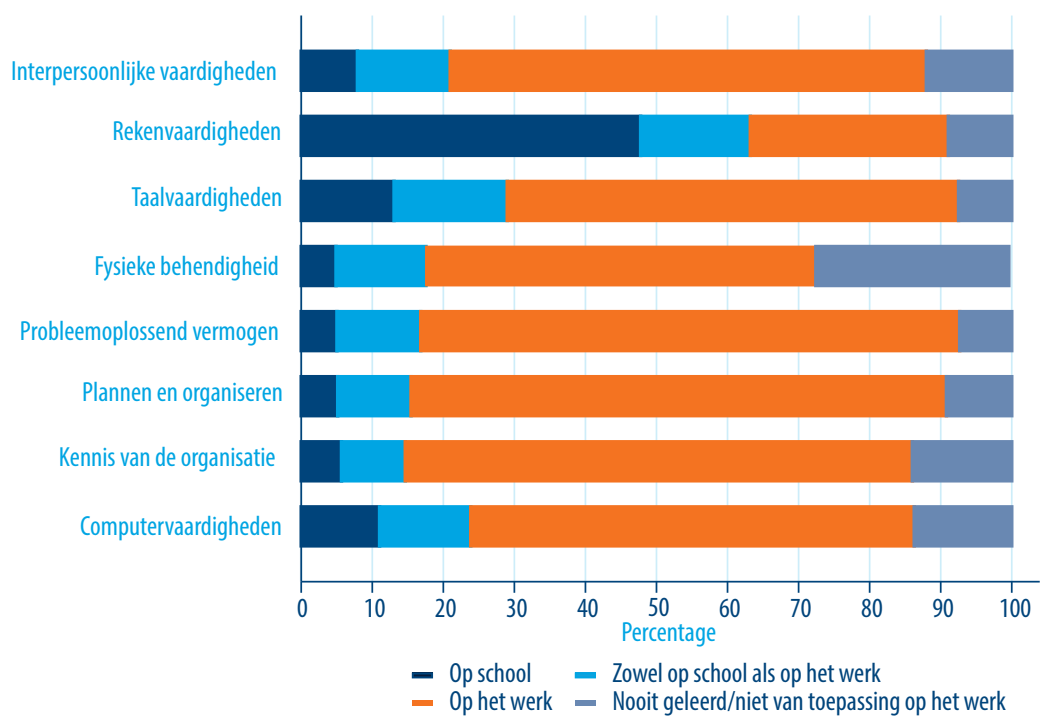

Bron: NSS, 2012 \& 2017

Het aandeel respondenten dat de taak nooit geleerd heeft neemt duidelijk af als we een controle uitvoeren voor het belang van de taken. Enkel fysieke behendigheid springt er in dit opzicht nog bovenuit, 27 procent van de respondenten blijkt deze vaardigheid nooit geleerd te hebben. Het is in het geval van fysieke behendigheid niet uitzonderlijk dat men de taken niet geleerd heeft omdat deze vaardigheden ook aangeboren kunnen zijn.

Waar men bepaalde vaardigheden leert kan afhankelijk zijn van achtergrondkenmerken, zoals geslacht. Daarnaast zou het kunnen zijn dat hoogopgeleiden de vaardigheden vooral leren op school terwijl laagopgeleiden de vaardigheden eerder on-the-job zullen leren. Om de verschillen naar achtergrondkenmerk in kaart te kunnen brengen voeren we regressieanalyses uit waarin we controleren voor deze achtergrondkenmerken. Hierbij wordt een dummy variabele voor de mate waarin de vaardigheid op

$\overline{16}$ Enige vorm van belang houdt in dit geval in dat de waarde voor het belang van de taak hoger ligt dan 1. 
school geleerd wordt als afhankelijke variabele gebruikt. Deze dummy krijgt de waarde 1 wanneer de vaardigheid voornamelijk op school geleerd is (antwoord 1 of 2 op de betreffende vraag, zie hoofdstuk 2). Als er enige vorm van leren op het werk nodig is om de vaardigheid te leren krijgt de dummy de waarde o (antwoord 3, 4 of 5 op de betreffende vraag, zie hoofdstuk 2. De optie dat men de taken niet heeft geleerd wordt hier buiten beschouwing gelaten om de interpretatie van de resultaten gemakkelijker te maken. Tabel 5.1 laat de resultaten van deze regressies zien waar in de tweede regressie ook nog voor het belang op het werk van de taak wordt gecontroleerd.

\section{TABEL 5.1}

Mate waarin taak op school wordt geleerd (OLS-coëfficiënten)

\begin{tabular}{|c|c|c|}
\hline & (1) & (2) \\
\hline \multicolumn{3}{|c|}{ Groep waarbinnen taak valt (ref: Interpersoonlijke vaardigheden) } \\
\hline Rekenvaardigheden & $0,546^{* * *}$ & $0,510^{* * *}$ \\
\hline Taalvaardigheden & $0,105^{* * *}$ & $0,091^{* * *}$ \\
\hline Fysieke behendigheid & $0,014^{* * *}$ & 0,001 \\
\hline Probleemoplossend vermogen & $-0,010^{* * *}$ & 0,002 \\
\hline Plannen en organiseren & $-0,005$ & $-0,007^{*}$ \\
\hline Kennis van de organisatie & $-0,001$ & $-0,009^{* *}$ \\
\hline Computervaardigheden & $0,071^{* * *}$ & $0,057^{* * *}$ \\
\hline Vrouw & $-0,000$ & $-0,007$ \\
\hline \multicolumn{3}{|l|}{ Opleidingsniveau (ref: Laag) } \\
\hline Middelbaar & $-0,021^{* *}$ & $-0,015^{*}$ \\
\hline Hoog & $-0,006$ & 0,006 \\
\hline \multicolumn{3}{|l|}{ Leeftijdscategorie (ref: 15-34 jaar) } \\
\hline 35-54 jaar & $-0,082^{* * *}$ & $-0,082^{* * *}$ \\
\hline 55 jaar of ouder & $-0,096^{* * *}$ & $-0,101^{* * *}$ \\
\hline \multicolumn{3}{|l|}{ Meetjaar (ref: 2012) } \\
\hline 2017 & $-0,009^{*}$ & $-0,016^{* * *}$ \\
\hline Belang van de taak & & $-0,040^{* * *}$ \\
\hline Constante & $0,131^{* * *}$ & $0,269^{* * *}$ \\
\hline N & 27.873 & 27.873 \\
\hline R-kwadraat & 0,275 & 0,286 \\
\hline
\end{tabular}

*** $\mathrm{p}<0,01 ;{ }^{* *} \mathrm{p}<0,05 ;{ }^{*} \mathrm{p}<0,1$

Bron: NSS, 2012 \& 2017

Uit Tabel 5.1 komt naar voren dat rekenen, taal en computervaardigheden vaker op school wordt geleerd dan interpersoonlijke vaardigheden. Kennis van de organisatie wordt juist vaker op het werk geleerd. Verder komt naar voren dat middelbaar opge- 
leiden een vaardigheid vaker leren op het werk vergeleken met laagopgeleiden. Voor hoogopgeleiden is er geen significant verschil waar te nemen. Daarnaast laat Tabel 5.1 een duidelijk effect van leeftijd op de manier van leren zien. Hoe ouder de respondent hoe hoger de kans dat de vaardigheid op het werk is geleerd, bijvoorbeeld door het opbouwen van ervaring. Met betrekking tot geslacht komt er geen significant verschil naar voren in de manier waarop men de taken leert. Tot slot komt uit Tabel 5.1 naar voren dat er een klein verschil zit tussen de meetjaren. In 2017 werden vaardigheden iets vaker op het werk geleerd vergeleken met 2012.

\section{Alternatieve manieren van leren}

Zoals eerder aangegeven leert men niet uitsluitend op school of op het werk. Door het uitvoeren van activiteiten buiten school of het werk kan men immers ook effectiever worden in het uitvoeren van de taken op het werk. Wanneer je bijvoorbeeld in je vrije tijd bij je lokale sportvereniging meehelpt met het organiseren van een evenement zal je mogelijkerwijs beter worden in plannen en organiseren. Tabel 5.2 laat zien hoe respondenten aangeven vaardigheden te hebben geleerd, buiten school en werk. Dit is aan respondenten gevraagd voor een taak die volgens hen belangrijk is op het werk. Doordat er meerdere antwoorden mogelijk waren in de vragen, met uitzondering voor de keuze 'op geen enkele andere wijze', tellen de percentages niet op tot 100.

TABEL 5.2

Waar heeft men, buiten school of werk, de belangrijke taak geleerd

\begin{tabular}{|c|c|c|c|c|c|c|c|}
\hline Groep & $\begin{array}{r}\text { Vrijwil- } \\
\text { ligers- } \\
\text { werk } \\
\text { / } \\
\text { mantelzorg }\end{array}$ & $\begin{array}{r}\text { Activiteiten } \\
\text { met } \\
\text { kinderen }\end{array}$ & $\begin{array}{l}\text { Vrijetijds- } \\
\text { activiteiten }\end{array}$ & Opvoeding & $\begin{array}{l}\text { Van nature } \\
\text { aangeboren }\end{array}$ & Anders & $\begin{array}{r}\text { Op geen } \\
\text { enkele } \\
\text { andere } \\
\text { wijze }\end{array}$ \\
\hline Interpersoonlijke vaardigheden & 14 & 12 & 26 & 33 & 35 & 10 & 21 \\
\hline Rekenvaardigheden & 8 & 6 & 15 & 17 & 23 & 14 & 44 \\
\hline Taalvaardigheden & 5 & 4 & 11 & 13 & 16 & 21 & 45 \\
\hline Fysieke behendigheid & 7 & 4 & 19 & 25 & 40 & 11 & 27 \\
\hline Probleemoplossend vermogen & 8 & 8 & 17 & 30 & 34 & 11 & 30 \\
\hline Plannen en organiseren & 9 & 10 & 19 & 24 & 34 & 9 & 27 \\
\hline Kennis van de organisatie & 2 & 3 & 14 & 12 & 14 & 18 & 52 \\
\hline Computervaardigheden & 7 & 3 & 30 & 12 & 11 & 11 & 41 \\
\hline
\end{tabular}

Bron: NSS 2017

Uit Tabel 5.2 komt naar voren dat respondenten vaak aangeven dat de vaardigheden van nature aangeboren zijn. Deze optie wordt namelijk voor interpersoonlijke vaardigheden, fysieke behendigheid, probleemoplossend vermogen en plannen en organiseren het vaakst gekozen. Naast van nature aangeboren geven de respondenten voor deze taken ook vaak opvoeding als alternatieve leerwijze aan. Een optie die ook vaak gekozen wordt is opmerkelijk genoeg geen van deze activiteiten. Voor rekenvaardigheden, taal- 
vaardigheden, kennis van de organisatie en computervaardigheden geeft meer dan 40 procent van de respondenten aan ze de taak niet op een andere manier hebben geleerd. Dit duidt erop dat zij deze taken vooral op school of op het werk hebben geleerd. Tot slot zijn vrijetijdsactiviteiten ook een alternatieve wijze van leren die voor een aantal taken genoemd wordt. Vooral voor computervaardigheden zijn vrijetijdsactiviteiten een veel voorkomende manier van leren.

\subsection{Wat is de bijdrage van loopbaanstappen aan de ontwikkeling van arbeidsvaardigheden?}

Veranderingen in de arbeidsmarktpositie kunnen resulteren in de acquisitie van nieuwe vaardigheden. Zo laat onderzoek zien dat het veranderen van beroep positief correleert met kennisontwikkeling en dat de cursussen die werkenden volgen vaak gericht zijn op de loopbaanontwikkeling (Fouarge et al., 2018). Om een antwoord te geven op de vraag wat de bijdrage is van loopbaanstappen aan de ontwikkeling van arbeidsvaardigheden gaan wij ten eerste in op de relatie tussen de verandering van arbeidsmarktpositie en verandering in belang en effectiviteit van taken. Ten tweede gaan wij in op de relatie tussen levenslang leren activiteiten en (veranderingen in) taakeffectiviteit.

\section{Veranderingen van baan en beroep}

Baan- en beroepsveranderingen kunnen gevolgen hebben voor het belang van taken in het werk en de effectiviteit waarmee men de taken uitvoert. Dit komt doordat baan- en beroepsveranderingen leiden tot veranderingen in de taken die men moet uitvoeren, waardoor bepaalde taken in belang kunnen toe- of afnemen. Baan- en beroepsveranderingen kunnen ook resulteren in een hogere of juist lage taakeffectiviteit. Zo kan het enige tijd duren voordat men nieuwe taken goed onder de knie krijgt.

In deze paragraaf relateren wij de veranderingen in belang van en effectiviteit in taken aan baan- en beroepsveranderingen tussen 2012 en 2017 . Hierbij is het belangrijk om voor het niveau in belang en effectiviteit te controleren i.v.m. plafond- en bodemeffecten: bijvoorbeeld wanneer het belang van of effectiviteit in taken in 2012 maximaal was, dan is een verdere stijging niet mogelijk. De geschatte regressies hebben de volgende vorm:

$$
T_{i, 2017}-T_{i, 2012}=\alpha+\beta M_{i, 2012-2017}+\gamma X_{i, 2017}+\delta T_{i, 2012}+\mu
$$

waarbij $T_{i, t}$ staat voor het belang $(B)$ van of de effectiviteit $(E)$ in taken voor persoon $i$ in jaar $t\left(T_{i, 2017}-T_{i, 2012}\right.$ is positief als belang of effectiviteit toeneemt en negatief als het afneemt), $M_{i, 2012-2017}$ is een indicator voor arbeidsmobiliteit tussen 2012 en 2017 en $X_{i, 2017}$ staat een set van waargenomen kenmerken in 2017 (geslacht, opleidingsniveau, leeftijd en aantal maanden werkzaam bij de huidige werkgever). $a, \beta, \gamma$ zijn te schatten coëfficiënten (waarbij onze belangstelling vooral uitgaat naar $\beta$ ) en $\mu$ is een storingsterm. Vanzelfsprekend kunnen deze analyses alleen worden uitgevoerd voor de 
NSS-respondenten die zowel in 2012 als 2017 hebben meegedaan aan het onderzoek. $M_{i, 2012-2017}$ wordt op twee manieren geoperationaliseerd. Ten eerste kijken wij naar veranderingen van werkgever tussen 2012 en $2017 .{ }^{17}$ Ten tweede kijken wij naar veranderingen van beroep..$^{18}$

De resultaten zijn gepresenteerd in Tabel 5.3, waarbij voor elke groep van taken de relatie met verandering van werkgever wordt weergegeven (kolom (1)) en verandering van beroep (kolom (2)). De tabel laat zien dat veranderingen van werkgever gepaard gaan met een toenemend belang van rekenvaardigheden. De relaties tussen verandering van werkgever en andere taken zijn niet statistisch significant. Veranderingen van beroep gaan gepaard met een toenemend belang van rekenvaardigheden, probleemoplossend vermogen, en computervaardigheden, al zijn deze verbanden slechts significant op een $10 \%$ niveau. $^{19}$

Wij vinden geen significant verband tussen veranderingen van baan of beroep en de effectiviteit waarmee de taken worden uitgevoerd (Tabel 5.4). Ook wanneer gekeken wordt naar de algehele effectiviteit over alle taken heen vinden wij geen verband. Het LISS-panel bevat tevens twee vragen die informatief kunnen zijn over de aansluiting tussen vaardigheden van werkenden en de gevraagde vaardigheden op het werk: 1) 'Kunt $\mathrm{u}$ op een schaal van o tot 10 aangeven hoe uw kennis en vaardigheden aansluiten bij het werk dat u nu doet?', en 2) 'Kunt u op een schaal van o tot 10 aangeven of uw kennis en vaardigheden problemen geven bij de uitoefening van uw functie?'. Veranderingen in de antwoorden van respondenten op deze twee vragen tussen 2012 en 2017 blijken echter niet systematisch samen te hangen met veranderingen van werkgever of beroep.

17 Men is van werkgever veranderd als het aantal maanden bij de huidige werkgever in 2017 kleiner is dat het aantal maanden tussen de beide meetmomenten van de NSS in 2012 en 2017.

18 Wij kijken naar veranderingen in beroepsgroep (BRC2014) tussen de beide meetmomenten van de NSS in 2012 en 2017 (ROA/CBS, 2014).

19 Wij vinden ook geen significante relatie voor de onderliggende items van interpersoonlijke vaardigheden en taalvaardigheden. 





Paragraaf 5.1 heeft al een overzicht gegeven over hoe respondenten aangeven dat zij hun effectiviteit in taken denken te kunnen verbeteren. In deze paragraaf relateren wij de taakeffectiviteit aan levenslang leren activiteiten zoals cursusdeelname en informeel leren van taken op het werk. De deelname aan cursussen is gemeten in het LISS-panel en is gekoppeld aan de NSS-data. ${ }^{20}$ Informeel leren is gemeten in de NSS 2012 en in de 2017 ROA Levenslang Leren Enquête (ROA LLL 2017). ${ }^{21}$ Omdat deze enquête gehouden is onder deelnemers aan het LISS-panel kunnen de data op individueel niveau worden gekoppeld. Wij schatten het volgende model:

$$
E_{i, t}=\alpha^{\prime}+\beta^{\prime} C_{i, t}+\gamma^{\prime} \operatorname{In} f_{i, t}+\delta^{\prime} X_{i, t}+\mu^{\prime}
$$

waarbij $E_{i, t}$ staat voor de taakeffectiviteit van persoon $i$ in jaar $t, C$ een indicatorvariabele is voor cursusdeelname in het afgelopen jaar, Inf een indicatorvariabele is voor respondenten die meer leren op het werk dan een mediane werknemer, $X$ staat voor een set van waargenomen kenmerken (geslacht, opleidingsniveau, leeftijd en aantal maanden werkzaam bij de huidige werkgever). $\alpha^{\prime} \beta_{\prime}^{\prime} \gamma^{\prime} \delta^{\prime}$ zijn te schatten coëfficiënten (waarbij onze belangstelling vooral uitgaat naar $\beta^{\prime}$ en $\gamma^{\prime}$ ), en $\mu^{\prime}$ is een storingsterm. Wij schatten twee versies van dit model, een met en een zonder controle voor informeel leren. Het model wordt ten eerste geschat als gepoolde OLS met robuuste standaardfouten. Dit geeft inzicht in de correlatie tussen levenslang leren en taakeffectiviteit. Ten tweede maken wij gebruik van de panelstructuur van de data om een fixed effects model te schatten. Dit heeft als voordeel dat in dit model rekening gehouden kan worden met niet-waargenomen kenmerken van personen die bepalend zijn voor zowel de deelname aan levenslang leren als de taakeffectiviteit. Deze schattingen brengen ons dichterbij het causale effect van levenslang leren op taakeffectiviteit. ${ }^{22}$

De resultaten van het OLS-model zijn opgenomen in Tabel 5.5 en laten zien dat cursusdeelname positief correleert met een hogere taakeffectiviteit, behalve voor plannen en organiseren. Bijvoorbeeld, werkenden die in het afgelopen jaar een cursus hebben gevolgd hebben een 0,1 hogere score op rekenvaardigheden, waarbij de effectiviteit gemeten is op een schaal van 1 'bijna nooit effectief' tot 5 'altijd effectief'. Controleren voor informeel leren doet niets af aan deze positieve correlatie, behalve voor effectiviteit in computervaardigheden: de correlatie met cursusdeelname is niet meer significant terwijl dat wel het geval is voor informeel leren. Werkenden die meer dan

20 De gebruikte vraag luidt: Hebt $\mathrm{u}$ in de afgelopen 12 maanden opleidingen of cursussen gevolgd of volgt $u$ op dit moment één of meer opleidingen of cursussen? Hierbij zijn respondenten gevraagd hobbycursussen niet mee te tellen.

21 De gebruikte vraag luidt: Hoeveel procent van de werktijd besteedt $u$ aan taken waarvan u kunt leren?

22 Uiteraard zijn in het panel model geslacht en opleiding niet meegenomen omdat de variabelen per individu niet veranderen in de tijd. 
gemiddeld informeel leren van hun taken scoren bijna 0,2 punt hoger op computervaardigheden effectiviteit. Informeel leren correleert ook positief met andere taken, behalve voor plannen en organiseren en fysieke behendigheid. Daarnaast is de correlatie met rekenvaardigheden slechts significant op 10 procent-niveau. Eerder zagen wij al dat werkenden aangeven rekenvaardigheden vooral op school te leren.

Tabel 5.6 laat tevens zien dat cursusdeelname en informeel leren positief correleert met de algehele taakeffectiviteit, oftewel kunde (op schaal van 1-5, zie hoofdstuk 3) en de aansluiting tussen kennis en vaardigheden en het werk (op schaal van o-10) zoals gemeten in het LISS-panel. Met betrekking tot de vraag of kennis en vaardigheden problemen geven bij de uitoefening van de functie (eveneens in het LISS-panel bevraagd) vinden wij geen relatie met de cursusdeelname, maar vinden wij wel dat informeel leren negatief correleert met de ervaren problemen bij het uitvoeren van de functie.

De panelregressies in Tabel 5.7 suggereren dat veel van de correlaties in Tabel 5.5 niet causaal geïnterpreteerd kunnen worden. Met name cursusdeelname is niet significant gerelateerd aan kunde. Voor taalvaardigheden geldt zelfs dat werkenden die een cursus volgden een lagere effectiviteit in taalvaardigheden hebben. Werkenden die veel informeel leren scoren hoger op effectiviteit als het gaat om interpersoonlijke vaardigheden, taalvaardigheden en plannen en organiseren. Deze bevindingen blijven overigens staan als er in het model gecontroleerd wordt voor het belang van taken. Merk op dat het ontbreken van significante relaties tussen cursusdeelname en effectiviteit te maken kan hebben dat cursussen in sommige gevallen eerder een beloning zijn van de werkgever voor het goed functioneren van de werknemer (Polat et al., 2017), en dus niet per se bedoeld zijn om de effectiviteit te verhogen.

\section{Skills gap}

Eerder in paragraaf 4.2 is de mismatch tussen het belang van taken en de vaardigheden van werkenden besproken. De skills gap wordt gemeten als het verschil tussen de effectiviteit in taken $(E)$ en het belang van taken $(B): S G_{i, t}=E_{i, t}-B_{i, t}$. Negatieve waardes geven een skills tekort weer en positieve waardes een skills overschot. Wij schatten het volgende model als fixed effects model:

$$
S G_{i, t}=\alpha^{\prime \prime}+\beta^{\prime \prime} C_{i, t}+\gamma^{\prime \prime} \operatorname{Inf}_{i, t}+\delta^{\prime \prime} X_{i, t}+\varphi E_{i, t}+\mu^{\prime \prime}
$$

Informeel leren is zwak significant positief gecorreleerd met planning. Verder zijn cursusdeelname en informeel leren niet significant gerelateerd aan de skills gap voor andere taken. 
Ook een panelmodel waarin de skills gap als dummy variabele wordt gemodelleerd (waarbij de skills gap gelijk aan 1 is als de effectiviteit $E$ kleiner is dan het belang $B$ ) is geschat. Het laat zien dat informeel leren negatief correleert met een skills tekort op interpersoonlijke vaardigheden en probleemoplossend vermogen. Dit suggereert dat leren door te doen een positieve bijdrage heeft voor het niveau van vaardigheden. Cursusdeelname correleert niet significant met het skills tekort.

Als alternatief model is de skills gap in 2017 gemodelleerd als functie van de skills gap in 2012 en verandering van werkgever of verandering van beroep tussen de beide NSS-metingen:

$$
S G_{i, 2017}=\alpha^{\prime \prime \prime}+\beta^{\prime \prime \prime} M_{i, 2012-2017}+\delta^{\prime \prime \prime} X_{i, 2017}+\varphi^{\prime} S G_{i, 2012}+\mu^{\prime \prime \prime}
$$

Het laat zien dat voor de meeste taken geen significante relaties zijn tussen verandering van werkgever en de skills gap. De enige uitzondering betreft rekenvaardigheden: werkenden die van werkgever zijn veranderd rapporteren een grotere skills tekort dan werkenden die niet van werkgever zijn veranderd. Dit kan indicatief zijn voor het feit dat het nieuwe werk een groter beroep doet op dit soort vaardigheden. Een verandering van beroep is nooit significant gecorreleerd met een verandering in de skills gap. 


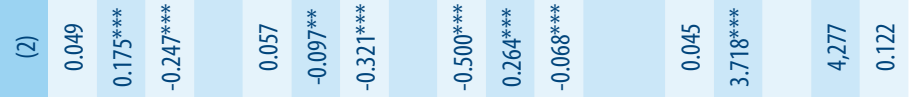

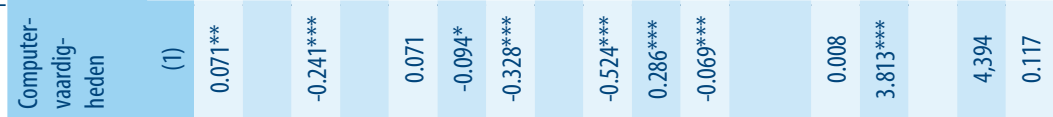

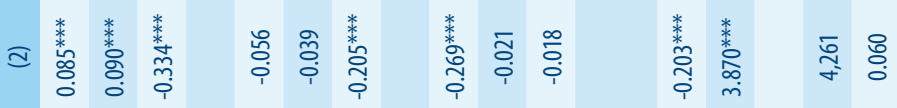

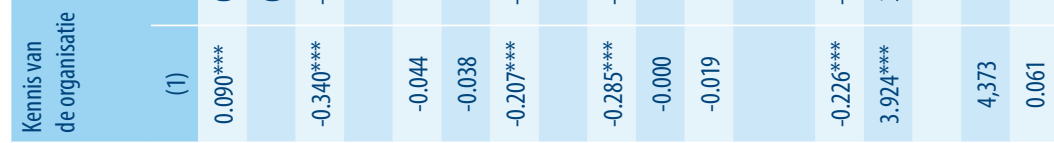

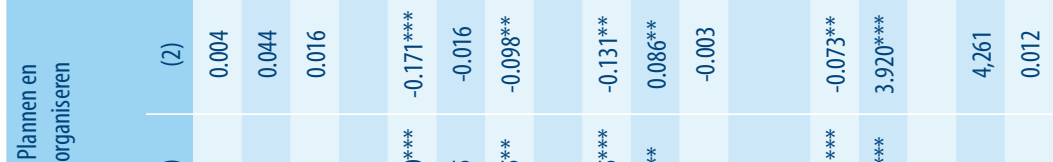

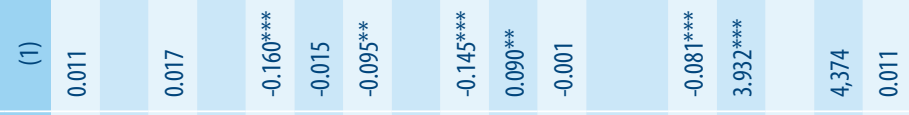

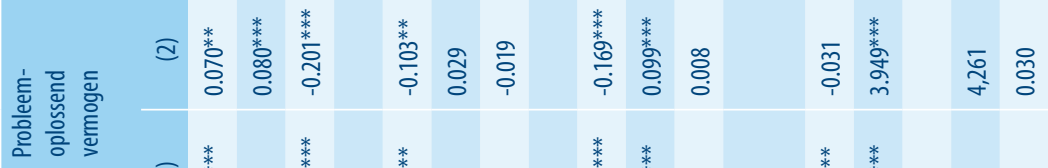

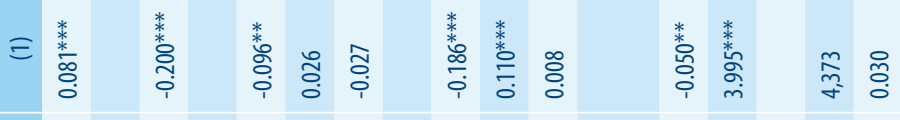

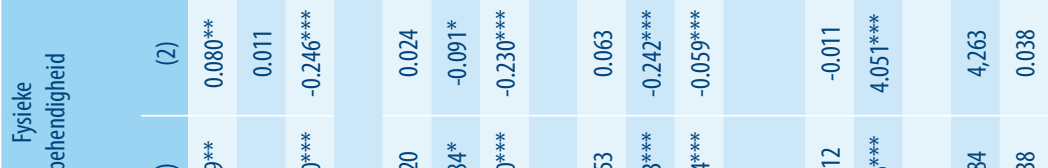

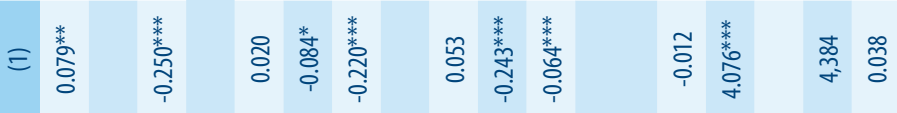

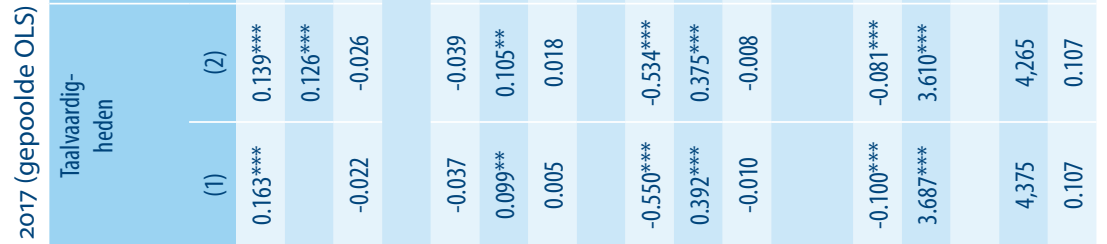

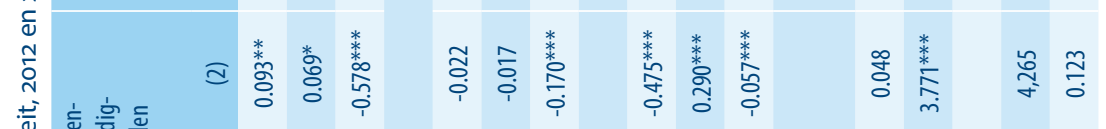

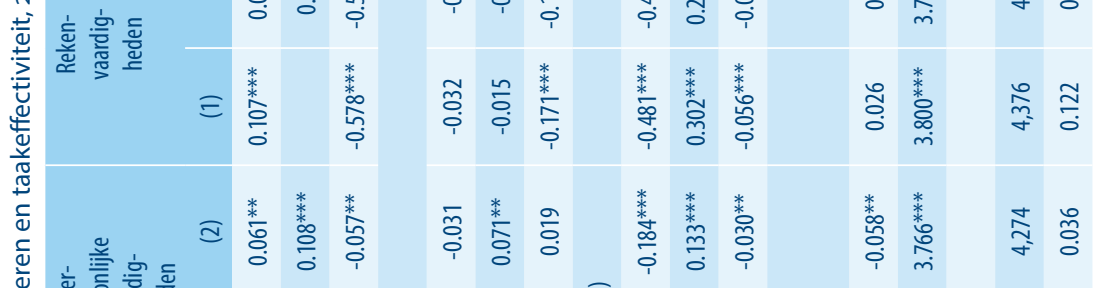

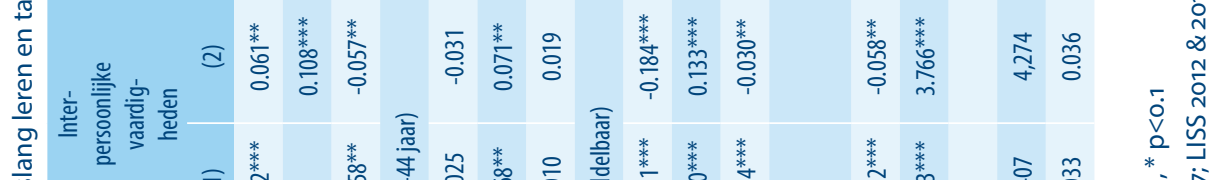

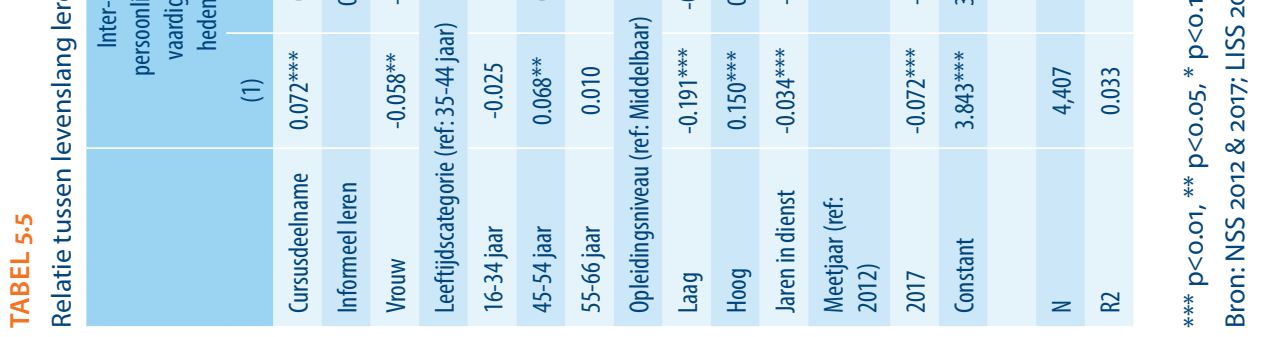


TABEL 5.6

Relatie tussen levenslang leren, taakeffectiviteit en aansluiting vaardigheden op functie, 2012 en 2017 (gepoolde OLS)

\begin{tabular}{|c|c|c|c|c|c|c|}
\hline & \multicolumn{2}{|c|}{ Kunde } & \multicolumn{2}{|c|}{$\begin{array}{l}\text { Aansluiting kennis en } \\
\text { vaardigheden op werk }\end{array}$} & \multicolumn{2}{|c|}{$\begin{array}{l}\text { Kennis en vaardigheden vormen } \\
\text { probleem bij het uitoefenen van } \\
\text { functie }\end{array}$} \\
\hline & (1) & (2) & (1) & (2) & (1) & $(2)$ \\
\hline Cursusdeelname & $0.090 * * *$ & $0.078^{* * *}$ & $0.258^{* * *}$ & $0.222^{* * *}$ & 0.032 & 0.036 \\
\hline Informeel leren & & $0.094^{* * *}$ & & $0.419 * * *$ & & $-0.161^{* * *}$ \\
\hline Vrouw & $-0.179^{* * *}$ & $-0.180^{* * *}$ & $-0.106^{*}$ & $-0.112^{*}$ & $0.179^{* * *}$ & $0.184^{* * *}$ \\
\hline \multicolumn{7}{|c|}{ Leeftijdscategorie (ref: 35-44 jaar) } \\
\hline 16-34 jaar & -0.023 & -0.032 & 0.024 & 0.006 & $-0.260^{* * *}$ & $-0.263^{* * *}$ \\
\hline 45-54 jaar & 0.018 & 0.019 & 0.104 & 0.123 & -0.010 & -0.014 \\
\hline 55-66 jaar & $-0.093^{* *}$ & $-0.088^{* *}$ & $0.191^{* *}$ & $0.222^{* * *}$ & 0.058 & 0.030 \\
\hline \multicolumn{7}{|c|}{ Opleidingsniveau (ref: Middelbaar) } \\
\hline Laag & $-0.301^{* * *}$ & $-0.288^{* * *}$ & $-0.319^{* * *}$ & $-0.274^{* * *}$ & 0.006 & -0.010 \\
\hline Hoog & $0.160^{* * *}$ & $0.146^{* * *}$ & $0.319^{* * *}$ & $0.289^{* * *}$ & -0.038 & -0.024 \\
\hline Jaren in dienst & $-0.029^{* *}$ & $-0.028^{* *}$ & $0.189^{* * *}$ & $0.193^{* * *}$ & 0.010 & 0.007 \\
\hline \multicolumn{7}{|l|}{ Meetjaar (ref: 2012) } \\
\hline 2017 & $-0.078^{* * *}$ & $-0.059^{* * *}$ & 0.014 & 0.055 & 0.031 & -0.005 \\
\hline Constant & $3.862^{* * *}$ & $3.805^{* * *}$ & $6.430^{* * *}$ & $6.166^{* * *}$ & $8.069^{* * *}$ & $8.184^{* * *}$ \\
\hline $\mathrm{N}$ & 4,448 & 4,3 & 4,351 & 4,198 & 4,35 & 4,198 \\
\hline $\mathrm{R} 2$ & 0.078 & 0.079 & 0.042 & 0.054 & 0.007 & 0.009 \\
\hline
\end{tabular}

*** $\mathrm{p}<0.01,{ }^{* *} \mathrm{p}<0.05,{ }^{*} \mathrm{p}<0.1$

Bron: NSS 2012 \& 2017; LISS 2012 \& 2017; ROA LLL 2017 


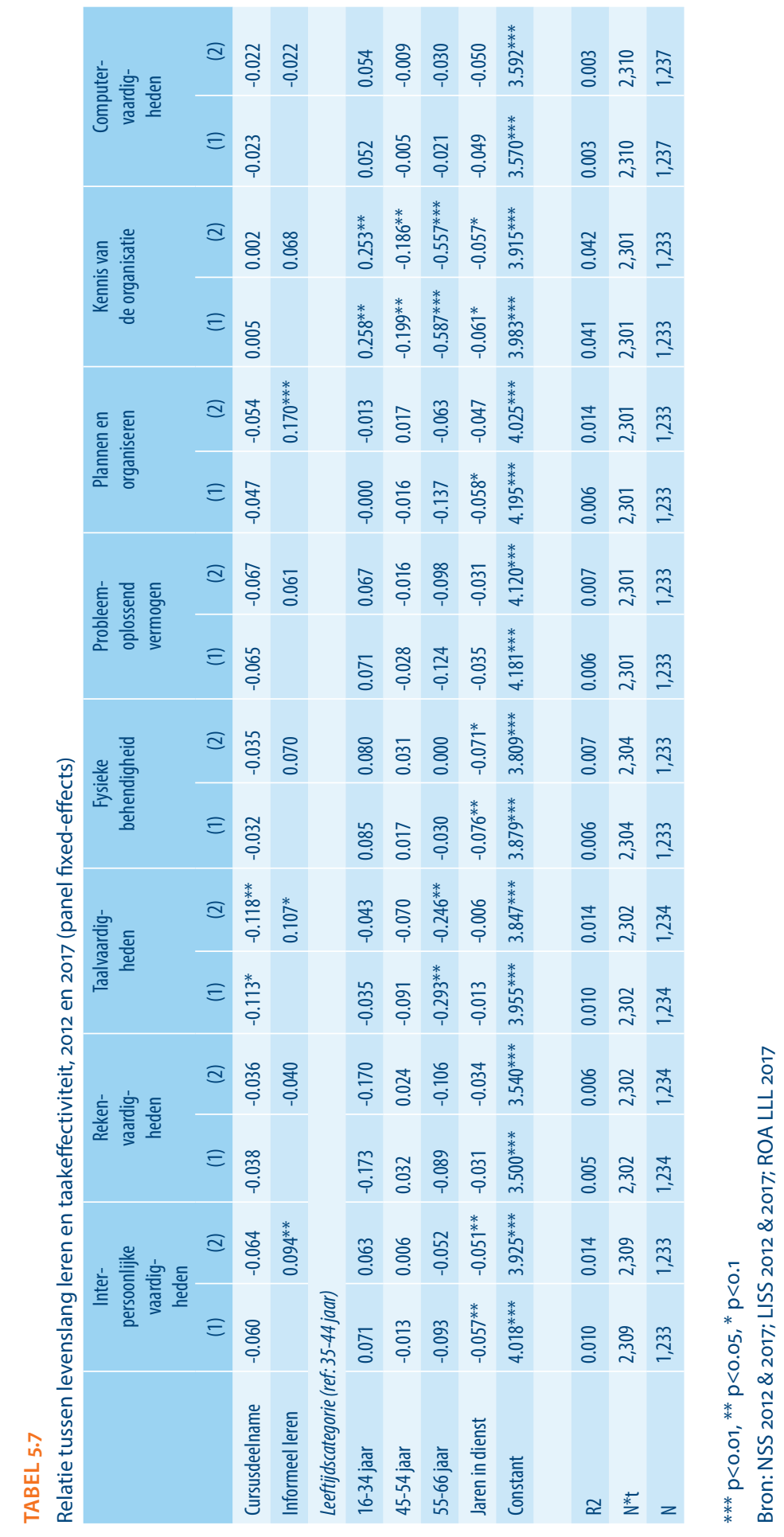





\section{VRAAG NAAR VAARDIGHEDEN EN ALLOCATIE VAN MENSELIJK KAPITAAL}

\subsection{Vraag naar vaardigheden in beroepen}

In eerdere hoofdstukken zijn het belang van taken en de effectiviteit in het uitvoeren van taken op individueel niveau besproken. Eerder onderzoek door Van den Berge en Ter Weel (2015) op basis van de oude CBS-beroepenclassificatie (SBC '92) liet zien dat het aandeel van de werkgelegenheid in beroepen die gekenmerkt zijn door (niet-) routinematige handvaardige taken en routinematige cognitieve taken gedaald is, maar dat het gestegen is in beroepen die hoog scoren op non-routine analytische en interactieve taken. Door de taken uit de NSS te koppelen aan de ontwikkeling in aantal werkenden per beroep zoals gemeten in de Enquête Beroepsbevolking (EBB), kunnen wij voor de periode 1996-2016 een beeld geven van de mate waarin de vraag naar bepaalde taken zich ontwikkelt.

\section{Belang van taken}

Figuur 6.1 laat per taak zien hoe de werkgelegenheid zich naar gelang het belang van de taak heeft ontwikkeld over tijd. De figuur is als volgt opgebouwd: Per beroepssegment is het gemiddeld niveau van belang van taken berekend, gebruik makend van de twee peilingen van de NSS om voldoende cel-vulling te garanderen. Vervolgens is een onderscheid gemaakt tussen beroepen met een hoog niveau van taken en beroepen met een laag niveau van taken aan de hand van de mediaan. ${ }^{23}$ Voor deze tweedeling van beroepen is de ontwikkeling van het aantal werkenden in de periode 1996-2016 afgebeeld, waarbij 1996 gebruik wordt als basisjaar. Zodoende is de ontwikkeling in het aantal werkenden in procentpunten af te lezen op de verticale as.

Uit de figuur komt naar voren dat de werkgelegenheid in de afgelopen 20 jaar sterker is gestegen in beroepen met een hoog niveau van interpersoonlijke vaardigheden, taalvaardigheden, probleemoplossend vermogen, plannen en organiseren en computervaardigheden. Beroepen die hoog scoren op fysieke behendigheid zijn minder snel gegroeid dan beroepen die daar laag op scoren. De werkgelegenheidsontwikkeling in

23 Bij deze analyse is rekening gehouden met de trendbreuk in de reeks van werkenden naar beroep als gevolg van het herontwerp van EBB. 
beroepen verschilt nauwelijks van elkaar voor beroepen die hoog of laag scoren op rekenvaardigheden of kennis van de organisatie. Deze bevindingen zijn in lijn met bevindingen voor de Verenigde Staten. Weinberger (2014), bijvoorbeeld, wijst op de groeiende complementariteit tussen cognitieve vaardigheden en interpersoonlijke vaardigheden.

\section{FIGUUR 6.1}

Ontwikkeling in aantal werkenden 1996-2016, naar belang van taken (1996=1)
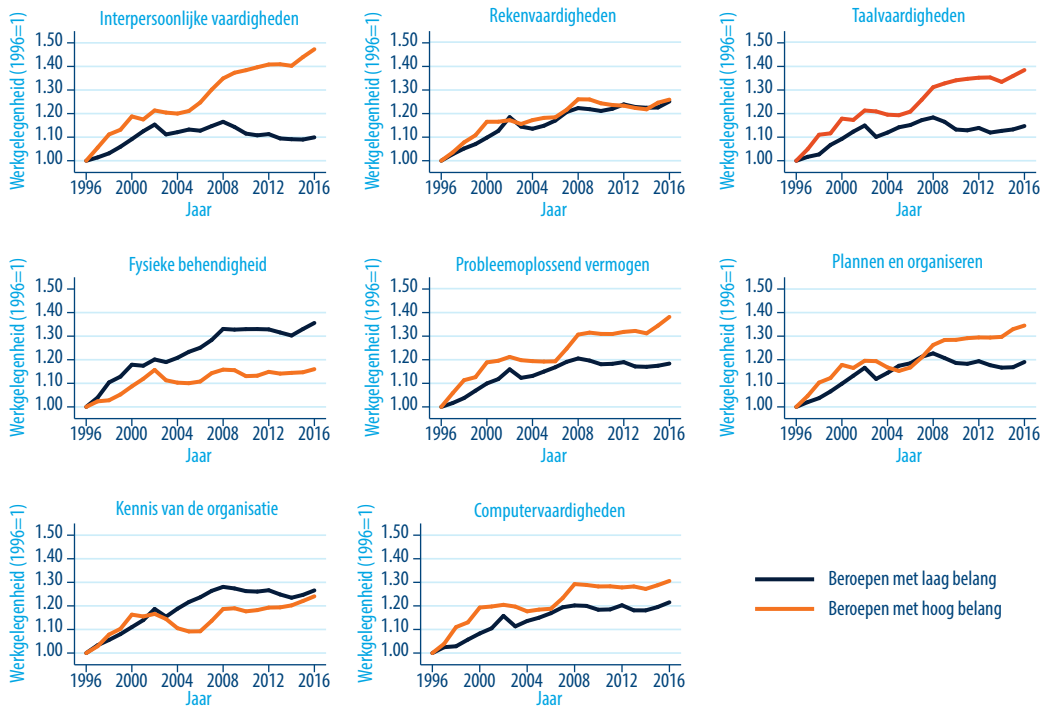

Beroepen met laag belang Beroepen met hoog belang

Bron: EBB, NSS

\section{Taakeffectiviteit}

Kijken wij naar de relatie tussen taakeffectiviteit en groei van de werkgelegenheid in beroepen, dan vinden wij dat vooral beroepen die hoog scoren op taakeffectiviteit in interpersoonlijke vaardigheden, taalvaardigheden, computer-vaardigheden en in iets mindere mate probleemoplossend vermogen sneller gegroeid zijn dan beroepen die hier laag op scoren (Figuur 6.2). Voor de andere vaardigheden zijn de verschillen in groei van de werkgelegenheid minder groot. 
FIGUUR 6.2

Ontwikkeling in aantal werkenden 1996-2016, naar taakeffectiviteit (1996=1)
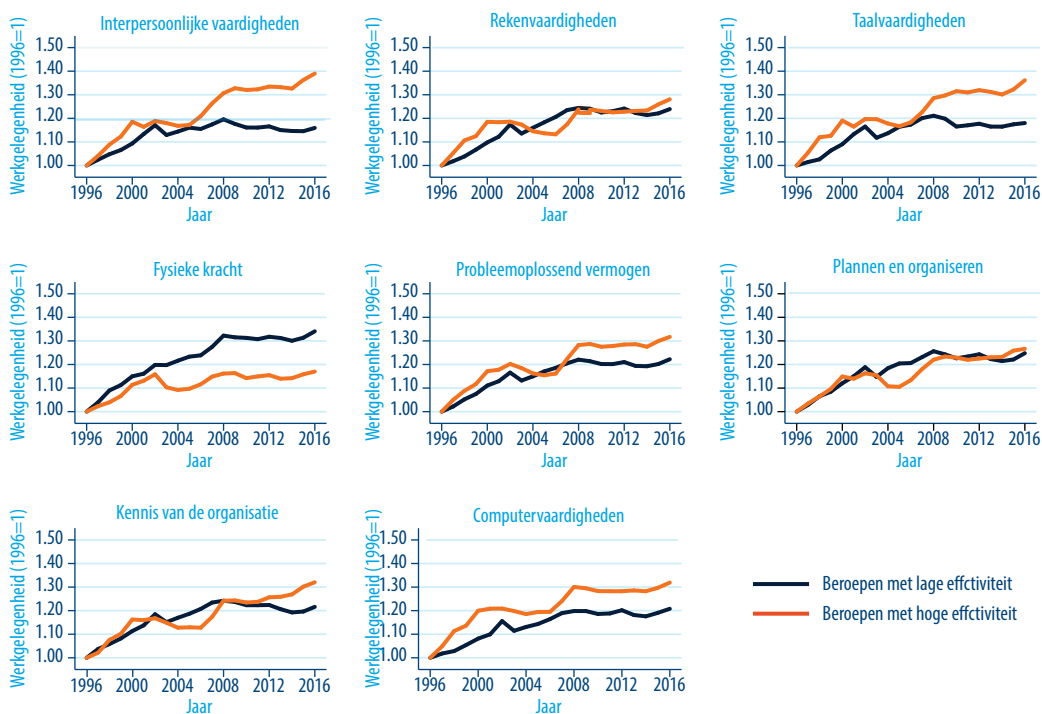

Bron: EBB, NSS

\section{Automatisering}

Onlangs publiceerde Nedelkoska en Quintini (2018) nieuwe schattingen van het automatiseringsrisico van beroepen in de OECD. De auteurs bouwen voort op het werk van Arntz et al. (2016) en verfijnen de schattingen van automatiseringsrisco's in beroepen van Frey en Osborne (2017) door rekening te houden met het feit dat kans op automatisering van beroepen afhankelijk is van de taakcompositie van die beroepen. Hun schattingen gaan uit van de taakcompositie van beroepen zoals gemeten in PIAAC. In Figuur 6.3 relateren wij de automatiseringskans in beroepen aan de ontwikkeling van het aantal werkenden. ${ }^{24}$ Hierbij maken wij een onderscheid tussen beroepen die hoger dan wel lager scoren dan de mediaan op de risico-indicator op automatisering. Het laat zien dat de groei van het aantal werkenden hoger is in beroepen met een laag risico op automatisering, terwijl de werkgelegenheid in beroepen met een hoog risico op automatisering nauwelijks is veranderd. Met andere woorden: het werkgelegenheidsaandeel van beroepen met een hoog risico op automatisering is in de afgelopen 20 jaar gedaald.

24 Met dank aan Glenda Quintini voor het beschikbaar stellen van het automatiseringsrisico van beroepen voor Nederland. 


\section{FIGUUR 6.3}

Automatiseringsrisico en groei van aantal werkenden 1996-2016 (1996=1)

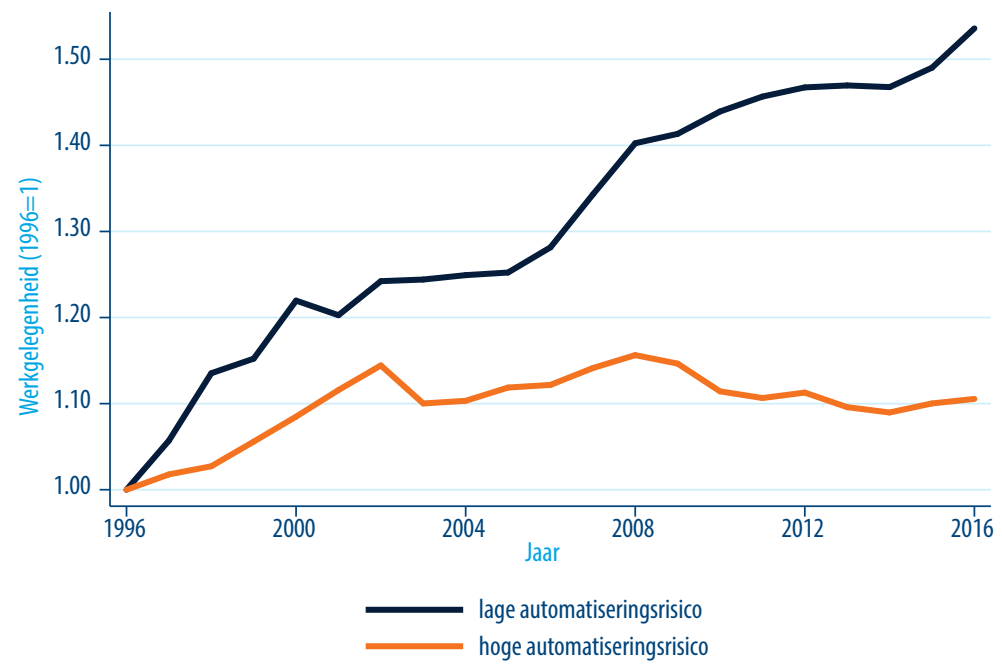

Bron: $E B B, O E C D$

Het automatiseringsrisico van beroepen correleert overigens negatief met het belang van alle taken behalve fysieke taken, waarbij de correlatie met kennis van organisatie relatief kleiner is vergeleken met andere taken.

\section{Loon en automatisering}

In een regressieanalyse vergelijkbaar aan degene die in Tabel 4.x (in hoofdstuk 4) is gepresenteerd, relateren wij het bruto uurloon aan de automatiseringskans van het beroep van de werkenden. De uitkomsten zijn weergegeven in Tabel 6.1 en laten zien dat een procent hogere automatiseringsrisico gepaard gaat met een 0,5\% lager uurloon. Dit suggereert dat automatisering niet alleen negatief gecorreleerd is met de werkgelegenheidsontwikkeling in beroepen, maar ook met de beloning/productiviteit in die beroepen. Automatisering is dan eerder een substituut voor arbeid dan complementair aan arbeid. 
TABEL 6.1

Regressie van bruto uurloon (in log) op automatiseringsrisico

\begin{tabular}{|c|c|}
\hline & $\begin{array}{c}\text { (1) } \\
\text { Bruto uurloon (in log) }\end{array}$ \\
\hline Automatiseringsrisico (in log) & $-0.542^{* * *}$ \\
\hline Vrouw & $-0.126^{* * *}$ \\
\hline \multicolumn{2}{|l|}{ Leeftijdscategorie (ref: 35-44 jaar) } \\
\hline 16-34 jaar & $-0.201^{* * *}$ \\
\hline 45-54 jaar & $0.031^{* *}$ \\
\hline 55-66 jaar & $0.122^{* * *}$ \\
\hline \multicolumn{2}{|c|}{ Opleidingsniveau (ref: Middelbaar) } \\
\hline Laag & $-0.093^{* * *}$ \\
\hline Hoog & $0.215^{* * *}$ \\
\hline Jaren in dienst & $0.027^{* * *}$ \\
\hline \multicolumn{2}{|l|}{ Meetjaar (ref: 2012) } \\
\hline 2017 & $0.054^{* * *}$ \\
\hline Constant & $2.301^{* * *}$ \\
\hline N & 3,570 \\
\hline $\mathrm{R}^{2}$ & 0.349 \\
\hline
\end{tabular}

Bron: NSS, 2012 \& 2017; OECD

\subsection{Veranderingen in het werk en taken van werkenden}

In de afgelopen twintig jaar is de beroepenstructuur in Nederland verschoven naar een gemiddelde hoger opleidingsniveau. Vanaf de jaren tachtig bedraagt de stijging van het opleidingsniveau ongeveer twee opleidingsjaren. Naast een flinke spurt in het opleidingsniveau van het arbeidsaanbod, kan ongeveer $40 \%$ van de stijging van het gemiddelde opleidingsniveau worden verklaard uit veranderingen in de beroepenstructuur: beroepen waarin veel hoogopgeleiden werken zijn sneller gegroeid. Een andere belangrijke verklaring is het stijgende opleidingsniveau binnen beroepen, wat suggereert dat er skills upgrading heeft plaatsgevonden. Onderzoek van Bijlsma et al. (2015) en Van den Berge en Te Weel (2015) suggereert dat deze upgrading het gevolg is van steeds hogere kwalificatie-eisen die werkgevers stellen aan werkenden die werkzaam zijn in een bepaalde functie omdat de relatieve lonen zijn blijven stijgen. Bij een overaanbod van hoogopgeleiden was dit niet het geval geweest. Tegelijkertijd is in de afgelopen twintig jaar ook sprake geweest van polarisering op de arbeidsmarkt, waarbij het aandeel van de werkgelegenheid in het middensegment van de loonverdeling is gekrompen ten gunste van banen aan de boven- en onderkant van de markt. Een drietal ontwikkelingen wordt vaak aangehaald als drijvende factoren achter deze skills upgrading en polarisering: technologische ontwikkeling, complexere organisatiestructuren en internationalisering (Katz en Autor, 1999; Caroli en Van Reenen, 2001). Deze ontwikkelingen zorgen 
niet alleen voor het verdwijnen van bepaalde beroepen, maar ook voor het ontstaan van nieuwe, vaak meer complexe beroepen. Tevens zorgen deze ontwikkelingen voor veranderingen in de manier waarop het werk georganiseerd en uitgevoerd wordt zowel in Nederland als in relatie tot het buitenland, en daarmee ook voor veranderingen in de vraag naar vaardigheden.

In deze paragraaf relateren wij het belang van taken en de skills gap aan een viertal door werkenden gerapporteerde ontwikkelingen (zie Tabel 6.3):

- De mate waarin technologische ontwikkelingen zich voordoen die de inhoud van het werk veranderen (dummy variabele voor grote tot zeer grote ontwikkelingen). $39 \%$ van de werkenden geeft aan dat grote tot zeer grote technologische ontwikkelingen zich voordoen.

- De mate waarin organisatorische ontwikkelingen zich voordoen die de inhoud van het werk veranderen (dummy variabele voor grote tot zeer grote ontwikkelingen). $33 \%$ van de werkenden geeft aan dat grote tot zeer grote organisatorische ontwikkelingen zich voordoen.

- De sterkte van de concurrentie in de markt waarin de organisatie opereert (dummy variabele voor grote tot zeer grote mate van concurrentie). $43 \%$ van de werkenden geeft aan dat er sprake is van grote tot zeer grote concurrentie in de markt waarin de organisatie opereert.

- De stabiliteit van vraag in de markt waarin de organisatie opereert (dummy variabele voor grote tot zeer grote instabiliteit). $16 \%$ van de werkenden geeft aan dat er sprake is van grote tot zeer grote instabiliteit in de markt waarin de organisatie opereert.

Deze ontwikkelingen zijn gemeten onder respondenten aan de ROA Levenslang Leren Enquête dat, evenals de NSS, in 2017 is afgenomen onder deelnemers aan het LISS-panel. Deze analyses kunnen enkel voor 2017 worden uitgevoerd omdat eerdere peilingen van de ROA LLL niet in het LISS zijn afgenomen.

TABEL 6.2

Mate waarin werkenden ontwikkeling in het werk percipiëren (procenten)

\section{Belang van taken en marktontwikkelingen}

In Tabel 6.4 relateren wij het belang van taken aan ontwikkelingen in het werk. Uit de tabel komt naar voren dat voor alle taken, behalve fysieke behendigheid, grote technologische veranderingen positief gecorreleerd zijn met het belang van de taken. Deze positieve correlatie is tevens voor organisatorische veranderingen in kaart te brengen, 
met uitzondering van fysieke behendigheid en rekenvaardigheden. Daarnaast komt uit de tabel naar voren dat de mate van concurrentie op de markt positief gecorreleerd is met het belang van interpersoonlijke vaardigheden, rekenvaardigheden, computervaardigheden, en in mindere mate met probleemoplossend vermogen. Tot slot blijkt dat de mate van instabiliteit in de markt niet correleert met het belang van taken op het werk. 


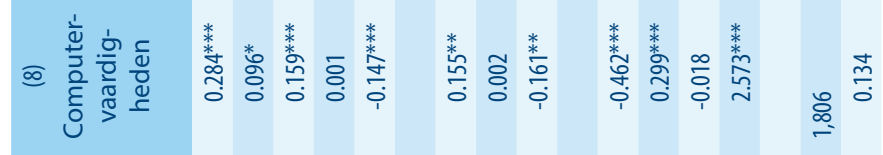

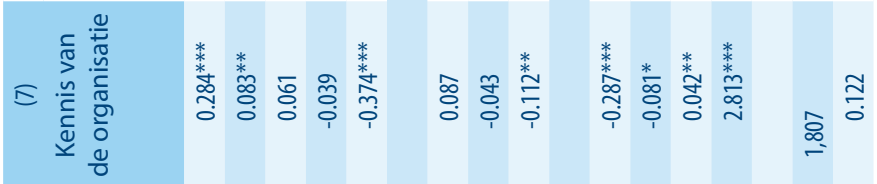

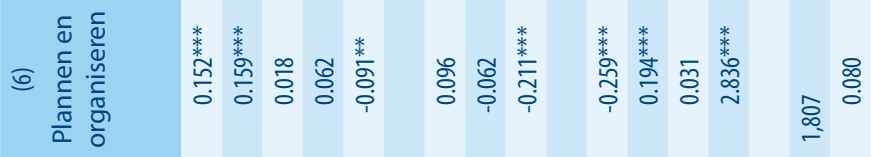

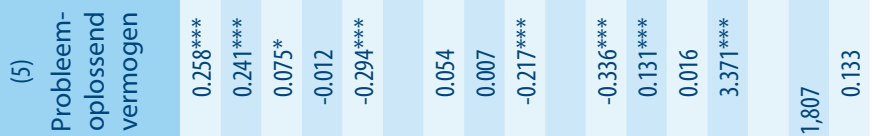

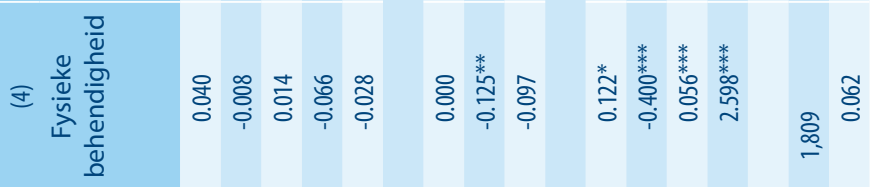

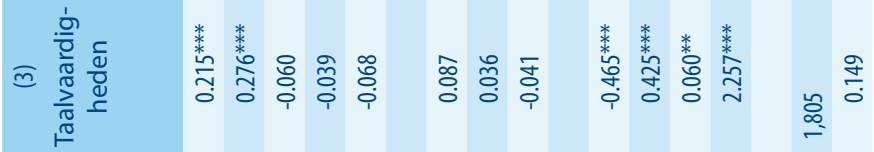

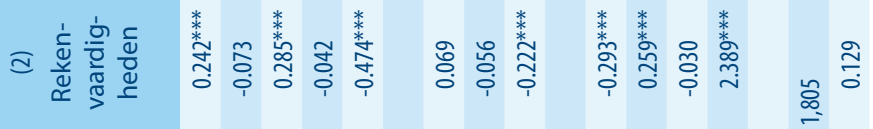

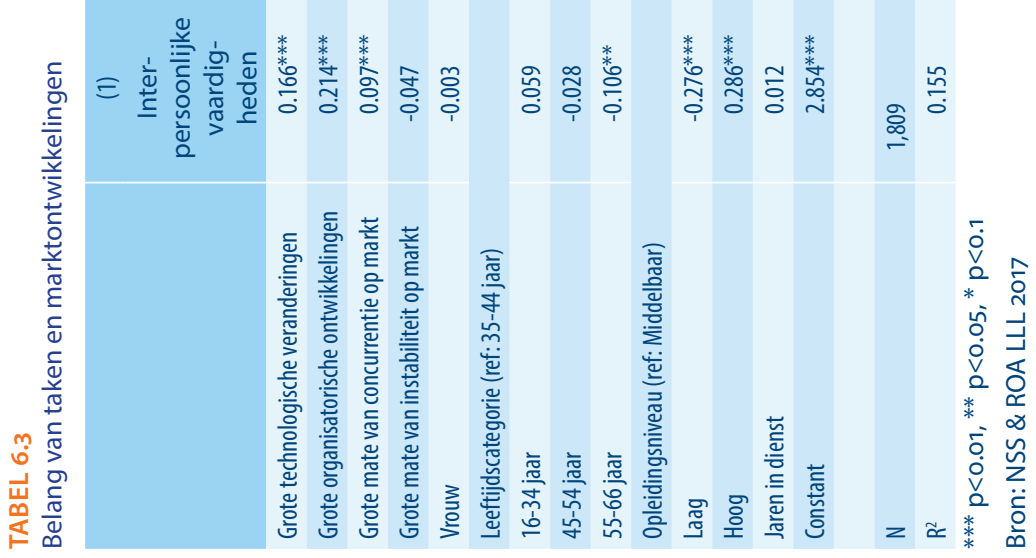




\section{Skills tekort, skills overschot en marktontwikkelingen}

Tabel 6.5 laat de resultaten zien van een analyse voor de kans op een skills tekort (bovenste gedeelte) en skills overschot (onderste gedeelte) en marktontwikkelingen. Grote technologische ontwikkelingen blijken samen te hangen met een kleinere kans op skills tekort in reken- en computervaardigheden. Dit suggereert dat dergelijke vaardigheden van belang zijn in technologie rijke omgevingen. Echter, grote technologische veranderingen hangen ook significant negatief samen met de kans op een skills overschot in probleemoplossend vermogen, en interpersoonlijke vaardigheden, kennis van de organisatie en computervaardigheden (al zijn deze verbanden zwak significant). Grote organisatorische veranderingen hangen positief samen met de kans op skills tekort op interpersoonlijke vaardigheden en computer vaardigheden. Dit zijn juist twee vaardigheden waarvoor de vraag groot is (Fouarge, 2017; Weinberger, 2014). Grote organisatorische veranderingen gaan bovendien gepaard met een kleinere kans op een skills overschot in interpersoonlijke vaardigheden, en een grotere kans op een skills overschot in rekenvaardigheden. Wij vinden een zwak significant verband tussen de mate van concurrentie op de markt en de kans op skills tekort in taalvaardigheden en fysieke behendigheid. Bij een grote mate van concurrentie is er tevens sprake van een grotere kans op een skills overschot in taal- en computervaardigheden. De mate van instabiliteit van de markt correleert niet met de kans op een skills tekort of overschot. 


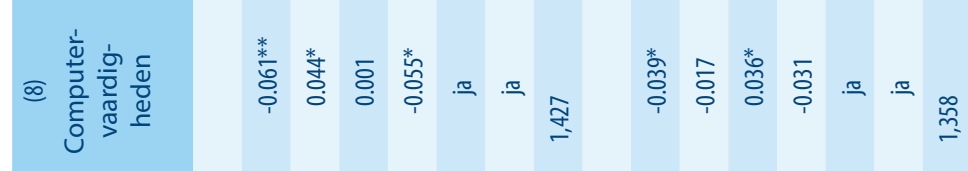

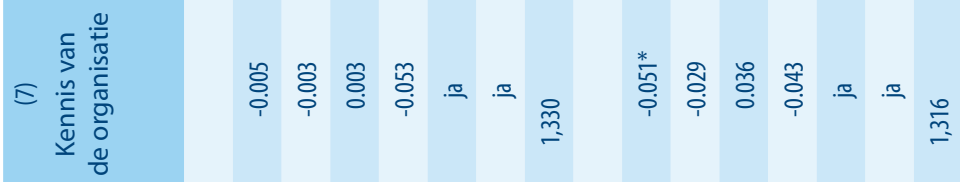

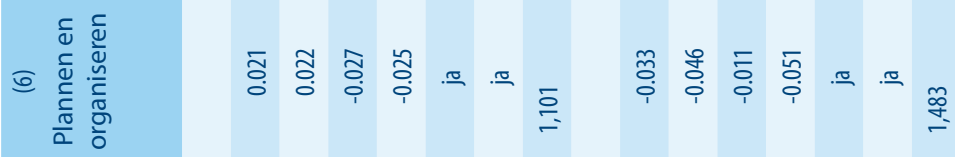

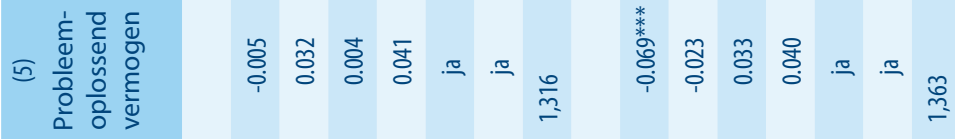

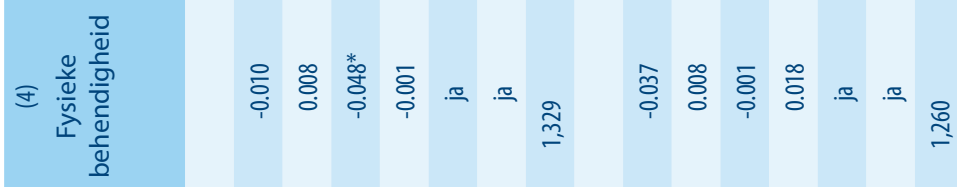

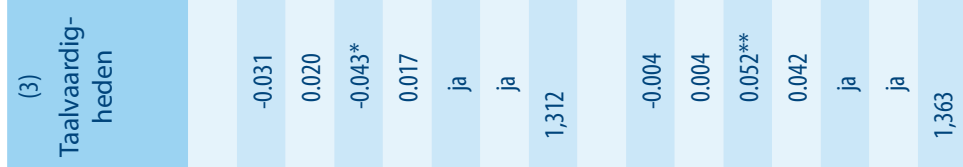

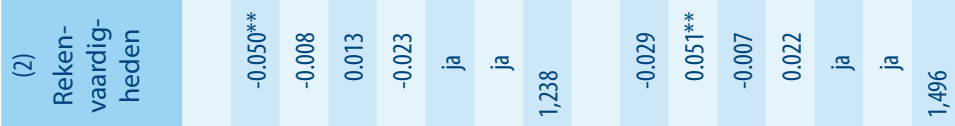

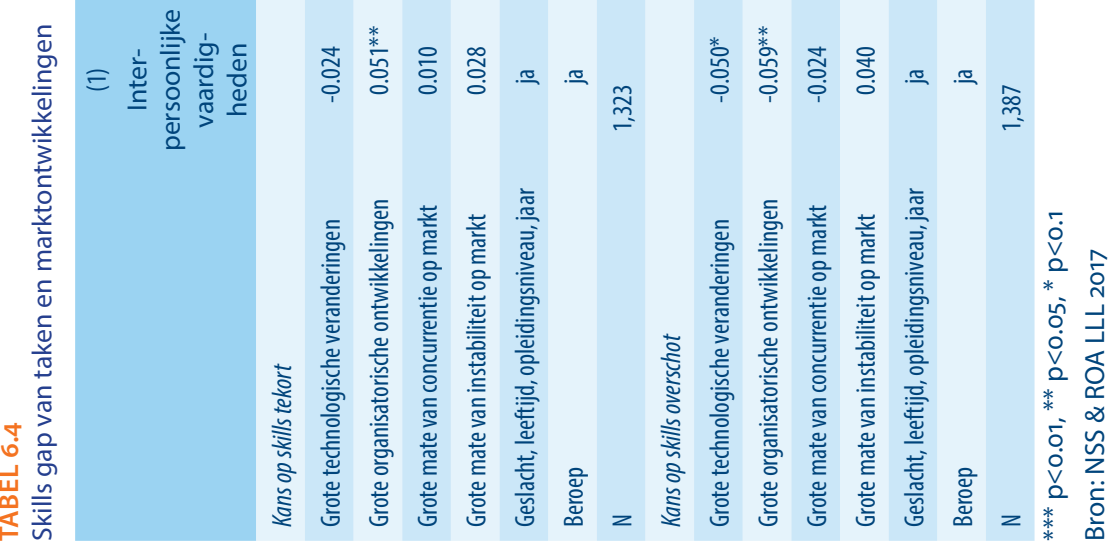




\section{VERGELIJKING VAN HET BELANG EN DE EFFECTIVITEIT VAN TAKEN TUSSEN WERKENDEN EN NIET-WERKENDEN}

In de vragenlijst van de NSS in 2017 zijn de vragen over taken en effectiviteit ook gesteld aan personen die op het moment van enquêteren niet werkzaam zijn. Hiermee is het ook voor de groep niet-werkenden mogelijk om vast te stellen welk belang zij hechten aan taken en hoe effectief zij deze zouden kunnen uitvoeren. Hiervoor is aan hen gevraagd om een beroep in gedachten te nemen die voor hen geschikt en haalbaar zou zijn. Een optie was ook om hiervoor hun eventuele laatste baan als referentiekader te nemen. Op basis van deze informatie is het mogelijk om een vergelijking te maken tussen werkenden en niet-werkenden ten aanzien van het belang en de effectiviteit van taken.

\section{Persoonskenmerken van werkenden en niet-werkenden}

In 2017 hebben in totaal 284 niet-werkenden meegedaan aan de NSS. Binnen deze groep is onderscheid gemaakt tussen personen die op zoek zijn naar werk $(n=84)$ en personen die dat niet zijn ( $n=200)$. In Tabel 7.1 zijn een drietal persoonskenmerken weergegeven van de werkenden en niet-werkenden. Allereerst valt op dat het aandeel vrouwen aanzienlijk groter in onder de niet-werkenden dan onder de werkenden. Dit komt met name doordat de groep niet werkenden die niet op zoek is naar werk voor ruim 90 procent bestaat uit vrouwen. Ook is er een verschil in leeftijd tussen werkenden en niet-werkenden. De werkenden zijn gemiddeld jonger dan niet-werkenden. Ook voor dit persoonskenmerk geldt dat het verschil met de niet-werkenden die niet op zoek zijn naar werk groter is dan met de niet-werkenden die dat wel zijn. 
TABEL 7.1

Kenmerken respondenten naar arbeidsmarktstatus

\begin{tabular}{|c|c|c|c|c|}
\hline & $\begin{array}{l}\text { Werkenden } \\
(n=1.856)\end{array}$ & $\begin{array}{l}\text { Niet-werkenden } \\
\qquad(n=284)\end{array}$ & $\begin{array}{r}\text { Niet-werkenden, } \\
\text { werkzoekend } \\
(n=84)\end{array}$ & $\begin{array}{r}\text { Niet-werkenden, } \\
\text { niet werk-zoekend } \\
(n=200)\end{array}$ \\
\hline \multicolumn{5}{|l|}{ Geslacht } \\
\hline Man & $52,4 \%$ & $17,6 \%$ & $40,2 \%$ & $8,4 \%$ \\
\hline Vrouw & $47,6 \%$ & $82,5 \%$ & $59,8 \%$ & $91,6 \%$ \\
\hline \multicolumn{5}{|l|}{ Leeftijd } \\
\hline 15-24 jaar & $3,5 \%$ & $2,0 \%$ & $3,5 \%$ & $1,4 \%$ \\
\hline 25-34 jaar & $17,4 \%$ & $8,0 \%$ & $14,9 \%$ & $5,1 \%$ \\
\hline 35-44 jaar & $22,6 \%$ & $10,9 \%$ & $12,6 \%$ & $10,2 \%$ \\
\hline 44-54 jaar & $29,2 \%$ & $23,2 \%$ & $20,7 \%$ & $24,2 \%$ \\
\hline 55-65 jaar & $27,4 \%$ & $56,0 \%$ & $48,3 \%$ & $59,1 \%$ \\
\hline \multicolumn{5}{|c|}{ Opleidingsniveau } \\
\hline Laag & $16,2 \%$ & $44,0 \%$ & $32,2 \%$ & $48,8 \%$ \\
\hline Middelbaar & $37,5 \%$ & $34,1 \%$ & $41,4 \%$ & $31,2 \%$ \\
\hline Hoog & $46,2 \%$ & $21,5 \%$ & $26,4 \%$ & $19,5 \%$ \\
\hline Onbekend & $0,1 \%$ & $0,3 \%$ & $0,0 \%$ & $0,5 \%$ \\
\hline
\end{tabular}

Bron: NSS 2017

\section{Verschil in het belang van taken tussen werkenden en niet-werkenden}

Voor vier van de acht geclusterde taken (interpersoonlijke vaardigheden, fysieke behendigheid, probleemoplossend vermogen en computervaardigheden) zijn statistisch significante verschillen gevonden tussen werkenden en niet-werkenden (Tabel 7.2). In alle gevallen hechten niet-werkenden gemiddeld een lager belang aan de taken dan werkenden. Bij de overige vier geclusterde taken (reken- en taalvaardigheden, organisatie en planning en kennis van de organisatie) is geen statistisch significant verschil gevonden tussen werkenden en niet-werkenden.

TABEL 7.2

Belang van taken naar arbeidsmarktstatus

\begin{tabular}{|l|r|r|r|r|}
\hline Geclusterde taken & Werkenden & $\begin{array}{r}\text { Niet-werkenden, } \\
\text { werkzoekend } \\
(n=84)\end{array}$ & $\begin{array}{r}\text { riet-werkenden, niet } \\
\text { werkzoekend } \\
(n=200)\end{array}$ & $\begin{array}{r}\text { Verschil tussen } \\
\text { werkenden en niet- } \\
\text { werkenden }\end{array}$ \\
\hline Interpersoonlijke vaardigheden & $3,800)$ & 3,16 & 2,93 & $* *$ \\
\hline Fysieke behendigheid & 2,63 & 2,89 & 2,88 & n.s. \\
\hline Kennis van de organisatie & 2,88 & 3,17 & 2,71 & $*$. \\
\hline Probleemoplossend vermogen & 3,48 & 3,57 & 3,19 & n.s. \\
\hline Plannen en organiseren & 3,06 & 3,09 & 2,93 & n.s. \\
\hline Taalvaardigheden & 2,78 & 2,94 & 2,66 & n.s. \\
\hline Rekenvaardigheden & 2,21 & 2,33 & 2,15 & $*$ \\
\hline Computervaardigheden & 2,68 & 2,82 & 2,41 & \\
\hline
\end{tabular}

Bron: NSS 2017 
Op eenzelfde manier zijn de potentiele verschillen in effectiviteit van taken tussen werkenden en niet-werkenden onderzocht (Tabel 7.3). Daaruit blijkt dat niet-werkenden gemiddeld significant minder effectief zijn in het uitvoeren van alle geclusterde taken dan werkenden.

TABEL 7.3

Effectiviteit van taken naar arbeidsmarktstatus

\begin{tabular}{|l|r|r|r|r|}
\hline Geclusterde taken & Werkenden & $\begin{array}{r}\text { Niet-werkenden, } \\
\text { werkzoekend } \\
(\mathrm{n}=84)\end{array}$ & $\begin{array}{r}\text { Niet-werkenden, niet } \\
\text { werkzoekend } \\
(\mathrm{n}=\mathbf{n}=200)\end{array}$ & $\begin{array}{r}\text { Verschil tussen } \\
\text { werkenden en niet- } \\
\text { werkenden }\end{array}$ \\
\hline Interpersoonlijke vaardigheden & $3,800)$ & 3,34 & 3,24 & $* *$ \\
\hline Fysieke behendigheid & 3,49 & 3,12 & 3,13 & $* *$ \\
\hline Kennis van de organisatie & 3,36 & 3,15 & 2,82 & $*$ \\
\hline Probleemoplossend vermogen & 3,92 & 3,63 & 3,30 & $* *$ \\
\hline Plannen en organiseren & 3,82 & 3,62 & 3,40 & $* *$ \\
\hline Taalvaardigheden & 3,71 & 3,38 & 3,15 & $* *$ \\
\hline Rekenvaardigheden & 3,35 & 2,98 & 2,68 & $* *$ \\
\hline Computervaardigheden & 3,36 & 3,19 & 2,77 & $* *$ \\
\hline
\end{tabular}

Bron: NSS 2017

Naast het in beeld brengen van de gemiddelde effectiviteit van werkenden en nietwerkenden in het uitvoeren van taken, is het ook mogelijk om naar de hele verdeling van beide groepen te kijken. Dit geeft een iets genuanceerder beeld van de verschillen tussen werkenden en niet-werkenden. Uit onderstaande Figuren 7.1 en 7.2 blijkt dat de effectiviteit van niet-werkenden gedeeltelijk overlapt met die van werkenden. De overlap is het grootst bij de groep niet-werkenden die op zoek zijn naar een baan en waarschijnlijk een kleinere afstand hebben tot de arbeidsmarkt.

\section{Verschil in mismatch van taken tussen werkenden en niet-werkenden}

Ten slotte vergelijken we ook de mismatch (indicator voor het verschil tussen effectiviteit en belang van taken in vier categorieën, zie hoofdstuk 4) tussen werkenden en niet-werkenden. De effectiviteit en het belang van taken is daartoe per individu gecorrigeerd voor het gemiddelde van de groep waartoe iemand behoort. In totaal zijn er drie groepen onderscheiden: de werkenden, de niet-werkenden op zoek naar werk en de niet-werkenden niet op zoek naar werk. Op basis van een vergelijking van de mismatch tussen deze groepen (zie Tabel 7.4) blijkt dat de niet-werkenden op vijf van de acht taken significant afwijken van werkenden. Waarbij de niet-werkenden hun mismatch veelal lager inschatten dan de werkenden, en binnen de groep niet-werkenden door de nietwerkzoekenden. De drie taken waarvoor geen significante verschillen zijn gevonden tussen werkenden en niet-werkenden op mismatch zijn interpersoonlijke, taal- en rekenvaardigheden. 


\section{FIGUUR 7.1}

Spreiding van de effectiviteit van geclusterde taken voor werkenden en niet-werkenden (onderscheid tussen werkzoekend en niet werkzoekend)
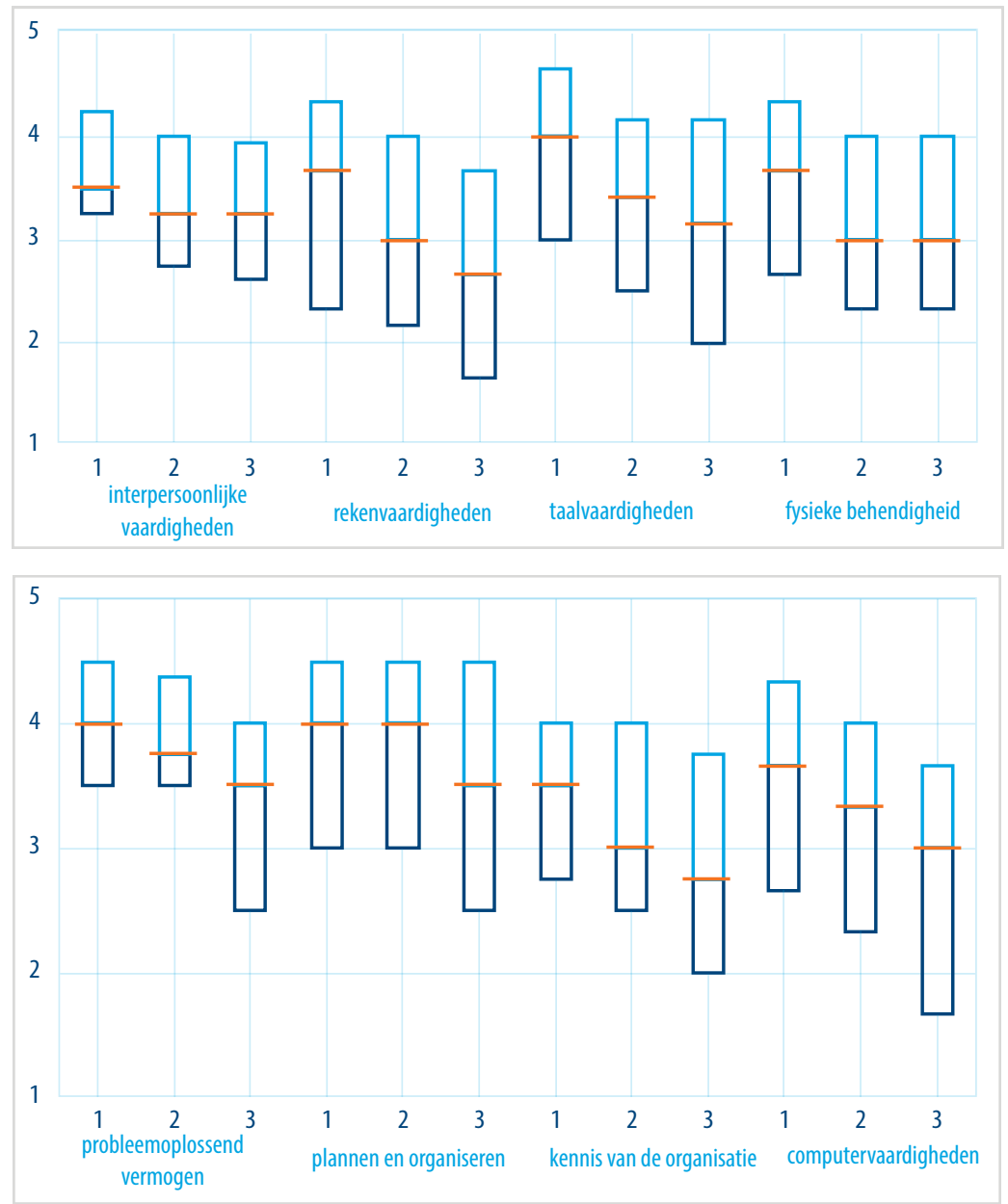

— mediaan en 1ste en 3de kwartiel

1=werkenden ( $n=1.800) ; 2=$ niet-werkenden, werkzoekend $(n=84) ; 3=$ niet-werkenden, niet werkzoekend $(n=200)$

Bron: NSS 2017 
TABEL 7.4

Mismatch onder werkenden en niet-werkenden

\begin{tabular}{|c|c|c|c|c|}
\hline & \multicolumn{2}{|c|}{ Match } & \multicolumn{2}{|c|}{ Mismatch } \\
\hline & $\begin{array}{l}\text { laag belang - } \\
\text { lage effectiviteit }\end{array}$ & $\begin{array}{l}\text { hoog belang - } \\
\text { hoge effectiviteit }\end{array}$ & $\begin{array}{l}\text { hoog belang - } \\
\text { lage effectiviteit }\end{array}$ & $\begin{array}{l}\text { laag belang - } \\
\text { hoge effectiviteit }\end{array}$ \\
\hline \multicolumn{5}{|c|}{ Niet-werkenden, werkzoekend ( $n=84$ ) } \\
\hline Interpersoonlijke vaardigheden & $37 \%$ & $37 \%$ & $14 \%$ & $12 \%$ \\
\hline Fysieke behendigheid & $29 \%$ & $30 \%$ & $27 \%$ & $14 \%$ \\
\hline Kennis van de organisatie & $30 \%$ & $35 \%$ & $21 \%$ & $14 \%$ \\
\hline Probleemoplossend vermogen & $24 \%$ & $36 \%$ & $20 \%$ & $20 \%$ \\
\hline Plannen en organiseren & $35 \%$ & $32 \%$ & $13 \%$ & $20 \%$ \\
\hline Taalvaardigheden & $33 \%$ & $38 \%$ & $17 \%$ & $12 \%$ \\
\hline Rekenvaardigheden & $36 \%$ & $36 \%$ & $9 \%$ & $19 \%$ \\
\hline Computervaardigheden & $30 \%$ & $42 \%$ & $13 \%$ & $15 \%$ \\
\hline \multicolumn{5}{|c|}{ Niet-werkenden, niet werkzoekend $(n=200)$} \\
\hline Interpersoonlijke vaardigheden & $28 \%$ & $40 \%$ & $17 \%$ & $18 \%$ \\
\hline Fysieke behendigheid & $30 \%$ & $35 \%$ & $24 \%$ & $11 \%$ \\
\hline Kennis van de organisatie & $32 \%$ & $39 \%$ & $20 \%$ & $9 \%$ \\
\hline Probleemoplossend vermogen & $28 \%$ & $36 \%$ & $20 \%$ & $16 \%$ \\
\hline Plannen en organiseren & $20 \%$ & $41 \%$ & $21 \%$ & $18 \%$ \\
\hline Taalvaardigheden & $30 \%$ & $39 \%$ & $17 \%$ & $14 \%$ \\
\hline Rekenvaardigheden & $40 \%$ & $32 \%$ & $14 \%$ & $14 \%$ \\
\hline Computervaardigheden & $36 \%$ & $38 \%$ & $13 \%$ & $13 \%$ \\
\hline \multicolumn{5}{|l|}{ Werkenden } \\
\hline Interpersoonlijke vaardigheden & $30 \%$ & $34 \%$ & $16 \%$ & $20 \%$ \\
\hline Fysieke behendigheid & $25 \%$ & $37 \%$ & $19 \%$ & $19 \%$ \\
\hline Kennis van de organisatie & $28 \%$ & $35 \%$ & $19 \%$ & $18 \%$ \\
\hline Probleemoplossend vermogen & $20 \%$ & $43 \%$ & $17 \%$ & $20 \%$ \\
\hline Plannen en organiseren & $29 \%$ & $30 \%$ & $10 \%$ & $31 \%$ \\
\hline Taalvaardigheden & $26 \%$ & $38 \%$ & $16 \%$ & $20 \%$ \\
\hline Rekenvaardigheden & $36 \%$ & $32 \%$ & $13 \%$ & $19 \%$ \\
\hline Computervaardigheden & $34 \%$ & $32 \%$ & $14 \%$ & $20 \%$ \\
\hline
\end{tabular}

Bron: NSS 2017 



\section{BELEIDSCONCLUSIE}

In dit rapport is gebruik gemaakt van de 2012 en 2017 peilingen van de NSS - aangevuld met informatie uit de LLL-enquête van het ROA - om inzicht te geven in het niveau en de ontwikkeling van taken en vaardigheden van werkenden in Nederland. We hebben gekeken naar 1) de ontwikkelingen in het belang van werktaken en de effectiviteit waarmee deze door werkenden worden uitgevoerd in 2012 en 2017, 2) de (mis)match tussen het belang van werktaken en de vaardigheden van werkenden die deze taken uitvoeren, 3) de relatie tussen investeringen in menselijk kapitaal en de effectiviteit waarmee taken worden uitgevoerd, en 4) de implicaties van technologische en organisatorische veranderingen voor het belang van werktaken in Nederland.

Meten

De ontwikkelingen in het niveau van taken en vaardigheden zijn gering in de periode 2012-2017. Over een periode van vijf jaar is dat stabiele patroon niet verrassend. Het stabiele patroon laat zien dat de NSS structurele kenmerken van de vraag naar en het aanbod van vaardigheden meet. Deze kenmerken zijn trouwens betekenisvol: analyses laten zien dat voor alle taken (behalve fysiek kracht) de beloning van werkenden toeneemt naarmate het belang van de taak groter wordt in een beroep en dat naarmate de match tussen vraag en aanbod beter is en de beloning hoger. Het gebrek aan grote ontwikkelingen geeft ook aan dat de meerwaarde van de NSS pas goed uit de verf komt als gemeten wordt over een langere tijdsperiode, zoals met de identieke British Skills Survey die vanaf 1997 loopt en de goed vergelijkbare BiBB-survey in Duitsland die al sinds de jaren '7o bestaat.

De conclusie is dat het meten van het belang van werktaken en de effectiviteit waarmee deze worden uitgevoerd na twee metingen een consistent beeld laten zien van de Nederlandse arbeidsmarkt. Volgende metingen zullen bijdragen aan nieuwe informatie en kennis over veranderingen in taken en vaardigheden tussen en binnen (nieuwe) beroepen, die waarschijnlijk langzaam tot stand komen. Het is van belang om deze metingen periodiek - zeg in het huidige ritme van eens per vijf jaar - voort te zetten. 


\section{Ontwikkelingen}

Tussen 2012 en 2017 is het (relatieve) belang van fysieke behendigheid en kennis van de organisatie afgenomen. Hetzelfde geldt voor de effectiviteit van kennis van organisatie en interpersoonlijke vaardigheden. Daar staat tegenover dat de effectiviteit in rekenvaardigheden is toegenomen. Voor de overige taken is er geen sprake van significante ontwikkelingen voor de werkende populatie als geheel. Dit beeld verandert nauwelijks wanneer er wordt ingezoomd op een groep werkenden die in beide jaren van de NSS hebben deelgenomen en voor wie zuiverder ontwikkelingen kunnen worden vastgesteld.

De grootste toename in effectiviteit is gemeten op het terrein van taken die te maken hebben met analytisch vermogen, zoals computergebruik en wiskunde. Dit is consistent met het algemene beeld dat in bijna alle beroepen analytische vaardigheden aan belang en waarde toenemen. Grote dalers zijn te zien op het terrein van kennis van producten en organisatie, wat consistent is met de toenemende codificatie van dit soort informatie in bedrijfsprocessen.

De conclusie is dat analytische en interpersoonlijke vaardigheden aan belang winnen in de Nederlandse arbeidsmarkt, omdat beroepen waarin deze taken van belang zijn groeien. De beloning van deze werktaken stijgt naarmate ze belangrijker zijn voor het uitvoeren van het werk, al valt op dat vraag en aanbod tamelijk goed in evenwicht zijn. Deze bevinding is consistent met studies in het buitenland en met analyses op andere databases (zoals PIAAC). Het zijn vaardigheden die complementair zijn aan ICT, organisatorische veranderingen en andere vormen van nieuwe technologie die de arbeidsmarkt beïnvloeden. Het toenemende belang van deze werktaken gaat vooralsnog gepaard met een passend aanbod binnen beroepen met de kanttekening dat er ook sprake is van onderkwalificatie. Voor sociale partners zou deze onderkwalificatie aanleiding kunnen zijn voor gerichte investeringen.

\section{Complexiteit en kunde van het werk}

De complexiteit van het werk neemt toe met het opleidingsniveau, wat betekent dat hoger opgeleiden meer taken gelijktijdig vervullen die van relatief groot belang zijn voor het effectief uitvoeren van hun werk dan lager opgeleiden. Bovendien neemt de complexiteit van het werk bij hoger opgeleiden veel langer toe met hun leeftijd en zijn zij in staat om hun taken effectiever uit te voeren gedurende hun gehele arbeidsloopbaan in vergelijking met lager opgeleiden.

De conclusie is dat lager opgeleiden en vooral lager opgeleide ouderen kwetsbaarder zijn voor veranderingen op het werk dan hoger opgeleiden. Lager opgeleiden hebben vaker een specialisme dat zich kenmerkt door een hoog belang van een beperkt aantal taken. Wanneer deze taken onder druk komen te staan - door bijvoorbeeld automatisering of internationale handel - ontstaat een kwetsbare arbeidsmarktsituatie. Hoger 
opgeleiden hebben daar vooralsnog minder last van, omdat zij meer taken uitvoeren die belangrijk zijn en met elkaar verbonden zijn. Het wegvallen van een van die taken is minder problematisch. De kwetsbare positie van lager opgeleiden is voor een deel op te lossen met meer mobiliteit. Uit de analyses komt naar voren dat werkenden die van beroep zijn veranderd vaker werktaken uitvoeren die het hogere belang van analytische vaardigheden bevestigen zonder dat hun effectiviteit sterk lager wordt.

\section{Vergelijking tussen werkenden en niet-werkenden}

Voor interpersoonlijke vaardigheden, fysieke behendigheid, probleemoplossend vermogen en computervaardigheden schatten niet-werkenden het belang van taken lager in dan werkenden. Met uitzondering van fysiek behendigheid gaat het om taken en vaardigheden waarnaar de vraag groot is. Niet-werkenden zijn ook minder effectief in die taken. Dit gebrek aan perceptie van belang kan gevolgen hebben voor de toekomstige inzetbaarheid van niet-werkenden op het moment dat zij ingezet zouden willen of moeten worden in het arbeidsproces. Deze gevolgen zijn groter naarmate niet-werkenden verder van de arbeidsmarkt af zijn komen te staan (langer niet hebben gewerkt).

De conclusie is dat niet-werkenden een achterstand hebben opgelopen en niet voldoen aan de eisen die worden gesteld aan het beroep dat ze in gedachten hebben. Het activeren van mensen om aan het werk te gaan zou daarom gebaat zijn bij een inschatting van het belang van kerntaken binnen een beroep en de afstand die werkzoekenden hebben tot deze kerntaken om ze in beroepen te laten instromen waar de match het meest effectief tot stand komt.

\section{Match tussen vaardigheden en taken}

Werkenden scoren hun effectiviteit in het uitvoeren van taken gemiddeld hoger in dan het belang van die taken in hun werk. Dit kan een indicatie zijn dat ze meer kunnen dan wat er van hen op het werk gevraagd wordt. Wat opvalt is dat er relatief gezien nauwelijks sprake is van mismatch in de zin van een hoog belang van taken in combinatie met een lage effectiviteit, een dergelijke mismatch gaat niet gepaard met lagere lonen (al kunnen we niet uitsluiten dat dit komt door het lage aantal waarnemingen). Blijkbaar zijn mensen over het algemeen goed in staat om taken met een hoog belang op een effectieve manier uit te voeren. In die zin lijkt er nauwelijks sprake te zijn van marktfalen in de allocatie van menselijk kapitaal in banen in de onderzochte periode. Let wel: het gaat hier om mensen en banen die al bij elkaar zijn gebracht.

Er zijn geen eenduidige verbanden tussen persoonskenmerken en de mate van mismatch. Voor interpersoonlijke vaardigheden, probleemoplossend vermogen, plannen en organiseren en rekenvaardigheden, neemt de mismatch af met de leeftijd en toe met het opleidingsniveau. Voor fysieke behendigheid, taalvaardigheden en computervaardigheden is sprake van het omgekeerde patroon. 
Voor de meeste taken geldt dat werkenden voor wie het belang van een taak laag is en de effectiviteit in deze taak ook laag ligt een significant lager uurloon verdienen, al geldt dit niet voor kennis van de organisatie en computervaardigheden. Dit suggereert dat een match op laag niveau indicatief is voor een laag niveau van productiviteit.

Een groot deel van de werkenden die belangrijke taken hebben, maar deze niet effectief uitvoeren, geeft aan dat de taken over vijf jaar nog belangrijk zullen zijn. Dit geldt vooral voor interpersoonlijke vaardigheden, kennis van de organisatie of gebruik van computers. De conclusie is dus dat mismatch zich niet vanzelf oplost en dat mensen moeten investeren in vaardigheden of mobiel moeten worden.

Door werkenden vaak genoemde manieren om hun effectiviteit te vergroten zijn het volgen van een cursus, het opdoen van ervaring door een werktaak vaker uit te voeren en het samenwerken met een meer ervaren collega. De conclusie is dat informeel leren een belangrijke rol speelt in het mogelijk verbeteren van de taakeffectiviteit. In beleidsdiscussies over de optimaliteit van investeringen in levenslang leren dient de belangrijke rol van informeel leren daarom niet te worden vergeten. Cursussen worden vaak genoemd om de effectiviteit van vooral computervaardigheden te vergroten. Informeel leren van taken/samenwerken wordt juist vaak genoemd voor taken als probleemoplossend vermogen, plannen en organiseren. Het is dus belangrijk dat werkgevers en werknemers voorwaarden creëren waardoor informeel leren mogelijk is om vraag en aanbod binnen de huidige baan goed op elkaar te laten aansluiten.

\section{Investeringen in menselijk kapitaal en taakeffectiviteit}

Werkenden geven aan rekenen, taal en computervaardigheden vaker op school te leren dan interpersoonlijke vaardigheden. Kennis van de organisatie wordt juist vaker op het werk geleerd. Sommige vaardigheden bezitten werkenden eerder van nature (interpersoonlijke vaardigheden, fysieke behendigheid, probleemoplossend vermogen en plannen en organiseren) dan via scholing of training.

Informeel leren en cursusdeelname correleren positief met de algehele taakeffectiviteit en de aansluiting tussen kennis en vaardigheden op het werk. Informeel leren correleert negatief met de ervaren problemen bij het uitvoeren van de functie, terwijl er voor cursusdeelname geen correlatie is. Nadere analyses waarbij rekening is gehouden met niet-waargenomen kenmerken van respondenten laten zien dat de relatie tussen cursusdeelname en taakeffectiviteit niet causaal geïnterpreteerd kan worden. Dit geldt in mindere mate voor informeel leren: werkenden die veel informeel leren scoren hoger op effectiviteit als het gaat om interpersoonlijke vaardigheden, taalvaardigheden en plannen en organiseren. Een belangrijke conclusie is dus dat informeel leren een belangrijke bijdrage kan leveren in het vergroten van de taakeffectiviteit, vooral als het gaat om specifieke taken. Het is goed om hierbij in ogenschouw te nemen dat vooral hoger opgeleiden werktaken uitvoeren waarbij informeel leren mogelijk is. 
Loopbaanstappen (veranderingen van baan en beroep) kunnen een impact hebben op het belang van taken of de effectiviteit in taken. Echter, de relaties tussen verandering van werkgever en het uitvoeren van andere taken die van belang zijn is niet statistisch significant. Veranderingen van beroep gaan gepaard met een toenemend belang van rekenvaardigheden, probleemoplossend vermogen, en computervaardigheden, al zijn deze verbanden niet precies te schatten. We vinden verder geen statistisch significant verband tussen veranderingen van baan of beroep en de effectiviteit waarmee de taken worden uitgevoerd. Dat geeft aan dat productiviteitsverliezen bij baanwisselingen gering zijn en dat de meeste baanwisselingen waarschijnlijk vrijwillig zijn. Bij niet-vrijwillige mobiliteit is de conclusie waarschijnlijk anders.

\section{Macro ontwikkelingen}

De werkgelegenheid is in de afgelopen 20 jaar sterker gestegen in beroepen met een hoog niveau van interpersoonlijke vaardigheden, taalvaardigheden, probleemoplossend vermogen, plannen en organiseren en computervaardigheden. Beroepen die hoog scoren op fysieke behendigheid zijn minder snel gegroeid dan beroepen die daar laag op scoren. De werkgelegenheidsontwikkeling in beroepen verschilt nauwelijks van elkaar voor beroepen die hoog of laag scoren op rekenvaardigheden of kennis van de organisatie.

Beroepen met een laag automatiseringsrisico zijn de snelste groeiers in de afgelopen 20 jaar. Automatisering drukt niet alleen de werkgelegenheidsontwikkeling in beroepen, maar ook de lonen van werkenden. De conclusie die hieruit naar voren komt is dat automatisering eerder een substituut voor arbeid is dan complementair aan arbeid. In beroepen met een hoog automatiseringsrisico is het opleidingsniveau vaak lager en de leeftijd van werkenden vaak hoger, wat nogmaals de kwetsbaarheid van lager opgeleiden en vooral lager opgeleide ouderen aangeeft.

Ook technologische, organisatorische en marktontwikkelingen zijn medebepalend voor het belang van taken. Voor de meeste taken geldt dat grote technologische of organisatorische veranderingen positief gecorreleerd zijn met het belang van de taken (behalve fysieke taken en voor organisatorische ontwikkelingen, rekenvaardigheden). Grote technologische en organisatorische ontwikkelingen blijken samen te gaan met een grotere skills gap op interpersoonlijke vaardigheden en probleemoplossend vermogen; twee vaardigheden waarnaar de vraag juist groot is. 



\section{LITERATUUR}

Acemoglu, D., \& Autor, D. (2011). Skills, tasks and technologies: Implications for employment and earnings. In: Handbook of Labor Economics, 4, 1043-1171.

Akçomak, I. S., Borghans, L., \& Ter Weel, B. (2011). Measuring and interpreting trends in the division of labour in the Netherlands. De Economist, 159(4), 435-482.

Arntz, M., Gregory, T., \& Zierahn, U. (2016). The risk of automation for jobs in OECD countries: A comparative analysis. Paris: OECD Social, Employment, and Migration Working Papers, (189), 0_1.

Autor, D., Levy, F., \& Murnane, R. (2003). The skill content of recent technological change: An empirical exploration. Quarterly Journal of Economics, 118(4), 1279-1333.

Berge, W. Van den, \& Ter Weel, B. (2015). Baanpolarisatie in Nederland. CPB Policy Brief 2015/13.

Bijlsma, I., Dijksman, S., Fouarge, D., \& Künn-Nelen, A. (2015). Winnaars en verliezers op de arbeidsmarkt 1996-2012. Tijdschrift voor Arbeidsvraagstukken, 31(2), 106-123.

Borghans, L., \& Golsteyn, B. (2013). Het meten van taken en vaardigheden. In: B. ter Weel \& S. Kok. De Nederlandse arbeidsmarkt in taken. Eerste bevindingen uit de Nederlandse Skills Survey. CPB: The Hague.

Borghans, L. \& Weel, B. ter (2006). The division of labour, worker organisation and technological change. Economic Journal, 116(509), F45-F72.

Borghans, L., Weel, B. ter, \& Weinberg, B. (2008). Interpersonal styles and labor market outcomes. Journal of Human Resources, 43(4), 815-58.

Borghans, L., Weel, B. ter \& Weinberg, B. (2014). People skills and the labor-market outcomes of underrepresented groups, Industrial and Labor Relations Review, 67(2), 287-334.

Bresnahan, T. F., Brynjolfsson, E., \& Hitt, L. M. (2002). Information technology, workplace organization, and the demand for skilled labor: Firm-level evidence. The Quarterly Journal of Economics, $117(1)$, 339-376.

Buisman, M., Allen, J., Fouarge, D., Houtkoop, W., \& van der Velden, R. (2013). PIAAC: Kernvaardigheden voor werk en leven. Resultaten van de Nederlandse survey 2012. 's Hertogenbosch: ECBO.

Caroli, E., \& Van Reenen, J. (2001). Skill-biased organizational change? Evidence from a panel of British and French establishments. Quarterly Journal of Economics, 116(4), 1449-1492.

Fouarge, D. (2017a). Veranderingen in de vraag naar vaardigheden. Tijdschrift voor het Economisch Onderwijs, 114 (6), 18-21.

Fouarge, D. (2017b). Veranderingen in werk en vaardigheden. Oratie, Maastricht University. 
Fouarge, D. \& A. de Grip (2013). Complexiteit, specialisatie en effectiviteit van het werk in Nederland. In: B. ter Weel \& S. Kok. De Nederlandse arbeidsmarkt in taken. Eerste bevindingen uit de Nederlandse Skills Survey. CPB: The Hague.

Fouarge, D., Eldert, P. van, Grip, A. de, Künn-Nelen, A., \& Poulissen, D. (2018). Nederland in leerstand. Maastricht: ROA-R-2018/4.

Frey, C. B., \& Osborne, M. A. (2017). The future of employment: how susceptible are jobs to computerisation?. Technological Forecasting and Social Change, 114, 254-280.

Goos, M., Manning, A., \& Salomons, A. (2014). Explaining job polarization: routine-biased technological change and offshoring. American Economic Review, 104(8), 2509-2526.

Katz, L. \& Autor, D. (1999). Changes in the wage structure and earnings inequality. In O. Ashenfelter \& D. Card (red.), Handbook of Labor Economics, vol. 3 (pp. 1463-1555), Amsterdam: Elsevier.

Los, B., Timmer, M. P., \& de Vries, G. J. (2015). How global are global value chains? A new approach to measure international fragmentation. Journal of Regional Science, 55(1), 66-92.

Miller, A., D. Treiman, P. Cain en P. Roose (1980). Work, jobs and occupations: A critical review of the Dictionary of Occupational Titles. Washington, DC: National Academy Press.

Nedelkoska, L., \& Quintini, G. (2018). Automation, skills use and training. Paris: OECD.

OECD (2013). OECD skills outlook 2013: First results from the Survey of Adult Skills. Paris: OECD Publishing.

Polat, T., Bal, M., \& Jansen, P.G.W. (2017). How do development HR practices contribute to employees' motivation to continue working beyond retirement age? Work, Aging and Retirement, 3, 366-378.

ROA/CBS (2015). Beroepenindeling ROA-CBS 2014 (BRC 2014). Maastricht: ROA-TR-2015/5.

Spenner, K.I., 1990, Skill: meaning, methods and measures, Work and Occupations, 17(2), 399-421.

Weel, B. ter, (2018). Nieuwe technologie transformeert de vraag naar arbeid. Economisch Statistische Berichten, 103, https://esb.nu/esb/20042797/nieuwe-technologie-transformeert-de-vraagnaar-arbeid.

Weel, B. ter, \& Kok, S. (2013). De Nederlandse arbeidsmarkt in taken. Eerste bevindingen uit de Nederlandse Skills Survey. CPB: The Hague.

Weinberger, C. (2014). The increasing complementarity between cognitive and social skills. Review of Economics and Statistics, 96(4), 849-861. 


\section{BIJLAGE A}

TABEL A.1

Welke taken zijn er geselecteerd voor Taak $A$, B en C

\begin{tabular}{|l|r|r|r|}
\hline Groep & Taak A & Taak B & Taak C \\
\hline Interpersoonlijke vaardigheden & 699 & 639 & 341 \\
\hline Rekenvaardigheden & 63 & 73 & 62 \\
\hline Taalvaardigheden & 158 & 238 & 107 \\
\hline Fysieke behendigheid & 113 & 157 & 100 \\
\hline Probleemoplossend vermogen & 315 & 338 & 73 \\
\hline Plannen en organiseren & 127 & 147 & 59 \\
\hline Kennis van de organisatie & 196 & 217 & 270 \\
\hline Computervaardigheden & 258 & 154 & 211 \\
\hline
\end{tabular}


